\title{
The Valuation of River Ecosystem Services
}

\author{
Dissertation \\ zur Erlangung des Doktorgrades \\ der Fakultät für Agrarwissenschaften \\ der Georg-August-Universität Göttingen
}

vorgelegt von

Wei Jiang

geboren in Fujian, VR China

Göttingen, November, 2016 
D 7

1. Referentin/Referent: Prof. Dr. Rainer Marggraf

2. Korreferentin/Korreferent: Prof. Dr. Heiko Faust

Tag der mündlichen Prüfung: 09.11.2016 


\section{Acknowledgement}

I would like to express my sincere gratitude to Professor Marggraf and Professor Faust for their guidance and encouragement in carrying out this dissertation. I also wish to thank my colleague in the division of environmental and resource economics who shared their knowledge and rendered their help. Last but not least, I appreciate my parents for their understanding and support during my doctoral period. 


\section{Table of contents}

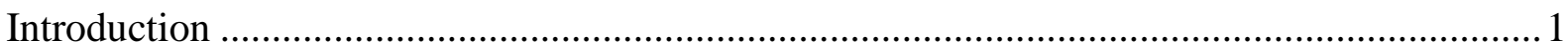

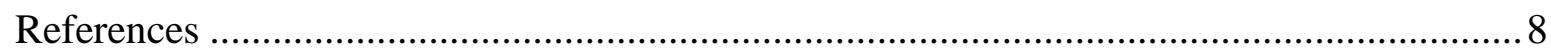

Paper 1: The origin of cost-benefit analysis: a comparative view of France and America........9

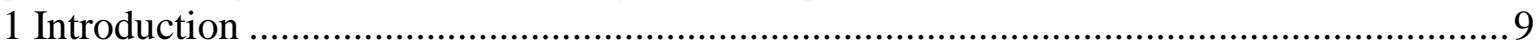

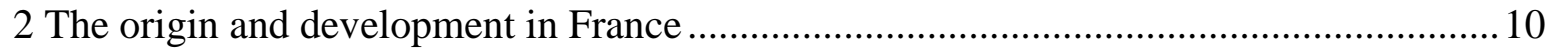

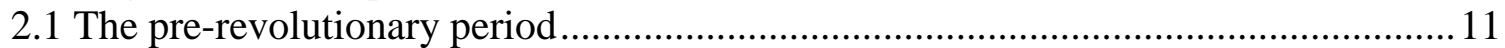

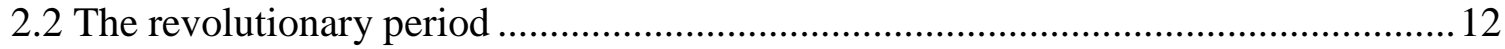

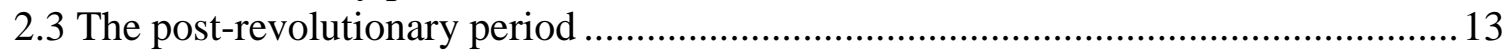

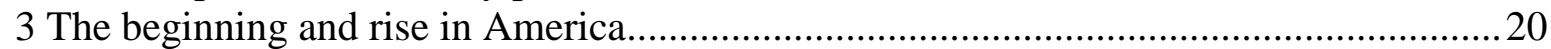

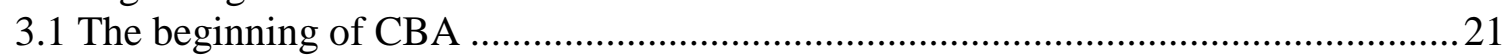

3.2 The issuing of the Green Book .............................................................................2

3.3 The Bureau of Reclamation and the Bureau of the Budget .......................................2

3.4 Takeover by the economists ……………………………………………….......2

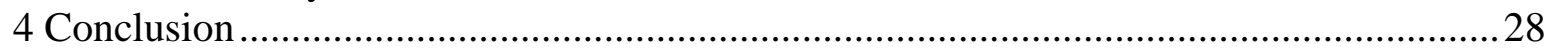

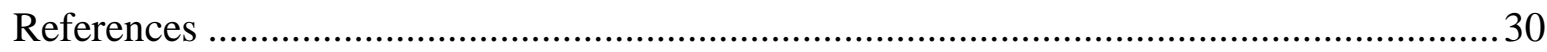

Paper 2: The historical development of environmental valuation methods and concepts in the

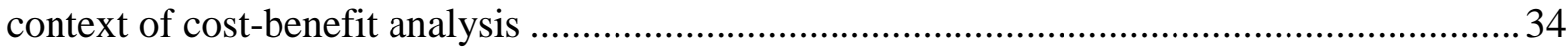

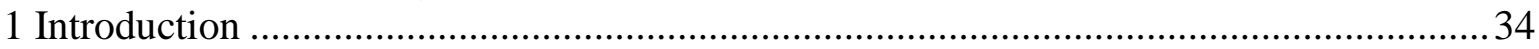

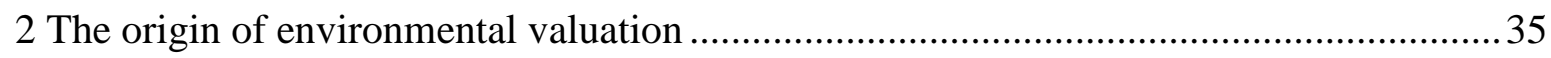

3 The further development of travel cost method.............................................................. 37

4 The further development of contingent valuation method .............................................. 42

5 The concept of total economic value ..........................................................................4

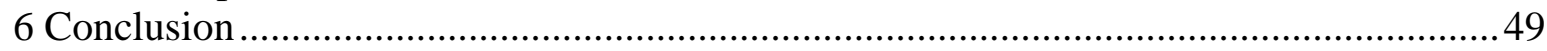

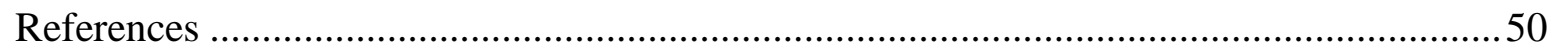

Paper 3: Ermittlung geeigneter Flächen für die Auenwaldetablierung in Niedersachsen anhand eines ökologisch-ökonomischen Auswahlkriteriums ……………………………………....6

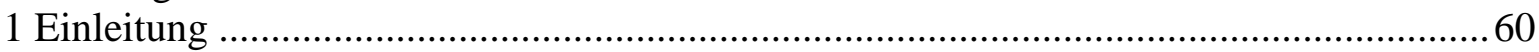

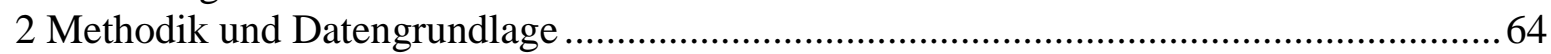

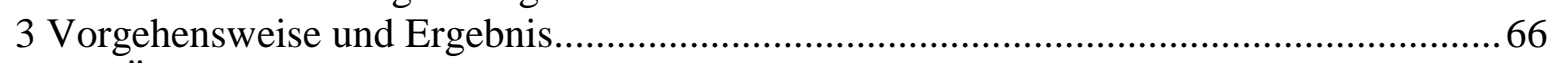

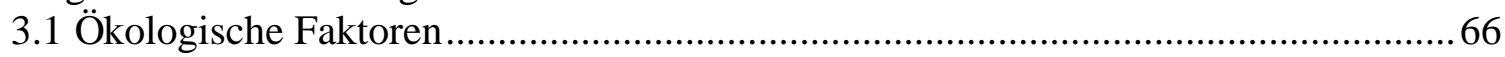

3.2 Kosten I: Ankauf von Flächen.............................................................................. 74

3.3 Kosten II: Anpflanzung von Auenwaldbestand ………………………................. 75

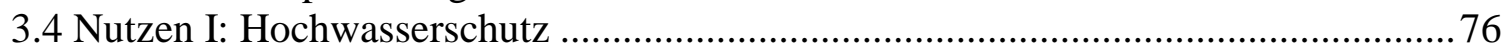

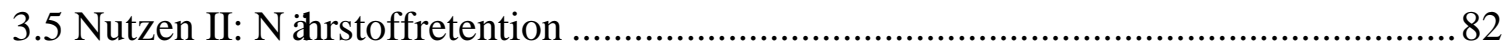

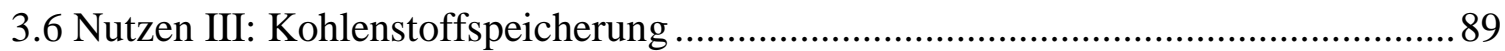

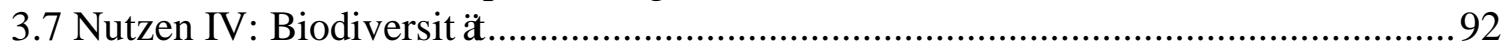

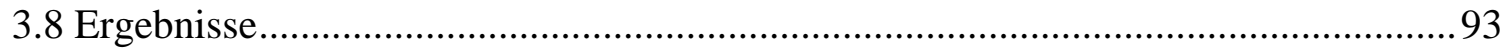

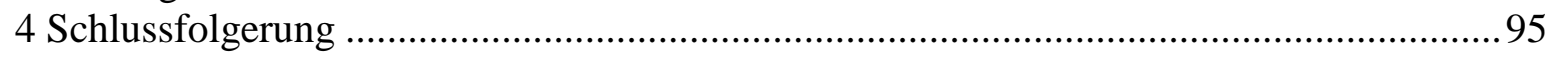

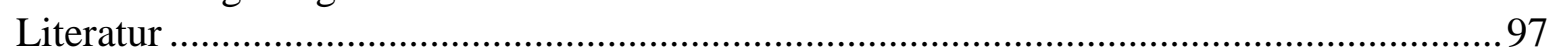

Paper 4: Assessing cultural ecosystem services through indicators: A case study of the Weser

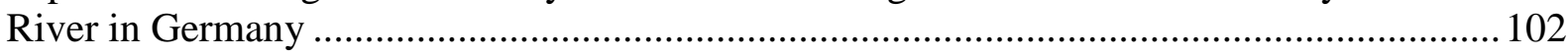

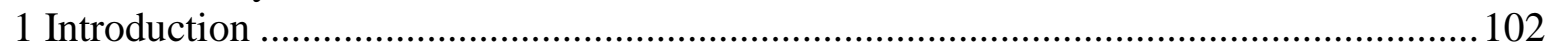

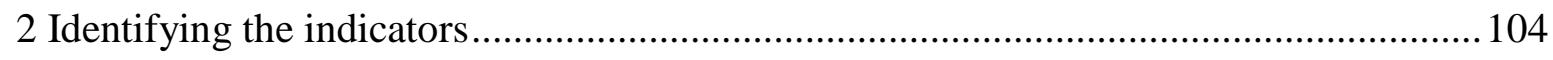




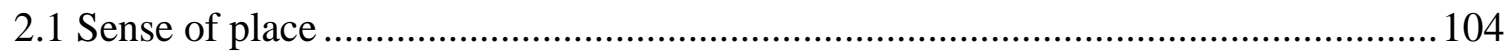

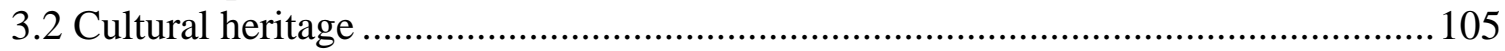

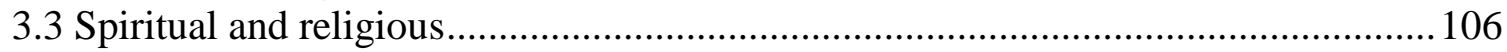

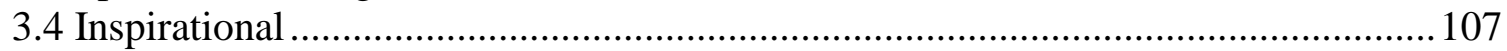

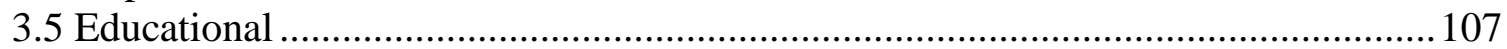

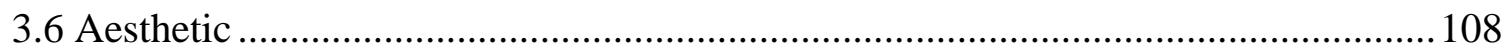

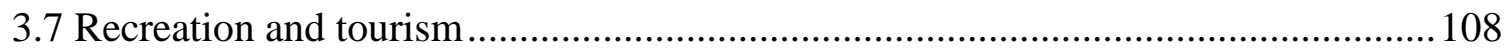

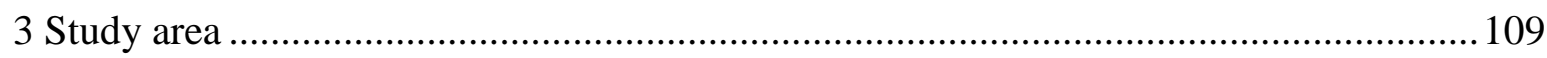

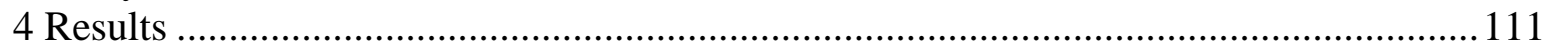

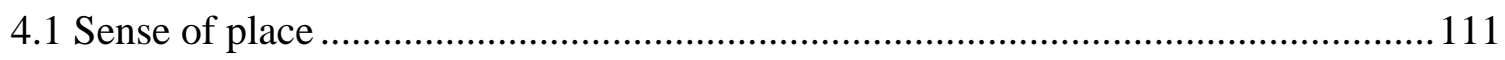

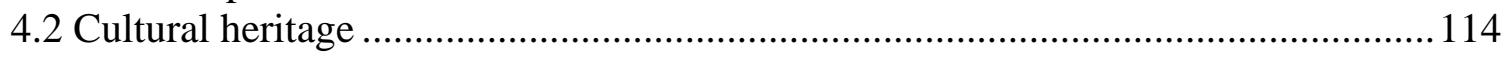

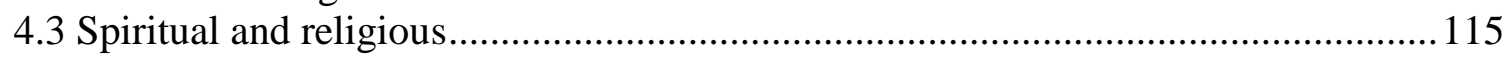

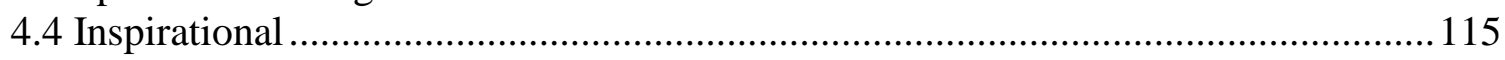

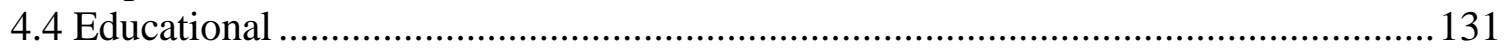

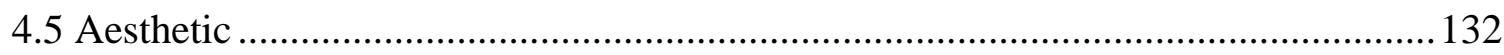

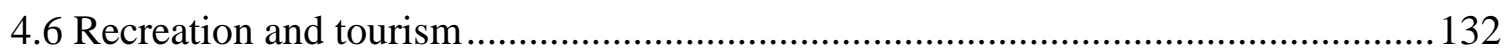

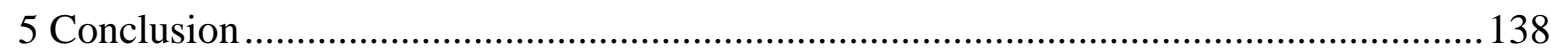

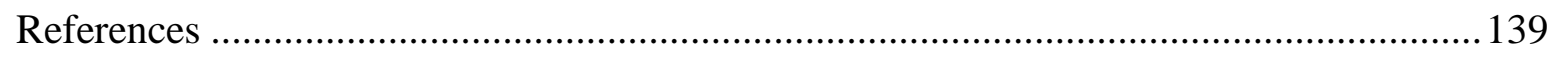

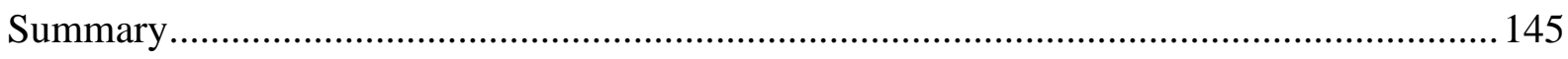




\section{Introduction}

Since the Millennium Ecosystem Assessment was released in 2005, ecosystem services have become the hot-spot research subject in the last decade. MA (2005a) defines ecosystem services as the benefits people obtain from ecosystems, including provisioning, regulating and cultural services that directly affect people and supporting services necessary to maintain the other services (Table 1). The conceptual framework of MA (2005b) places human well-being with five main constituents as the central focus and pays particular attention on the linkages between ecosystem services and human well-being by assuming that a dynamic interaction exists between people and other parts of ecosystems, with the changing human condition driving, both directly and indirectly, changes in ecosystems and thereby causing changes in human well-being. At the same time, many other factors (indirect drivers) unrelated to ecosystems alter the human condition, and many natural forces (direct drivers) influence ecosystems (Figure 1) 


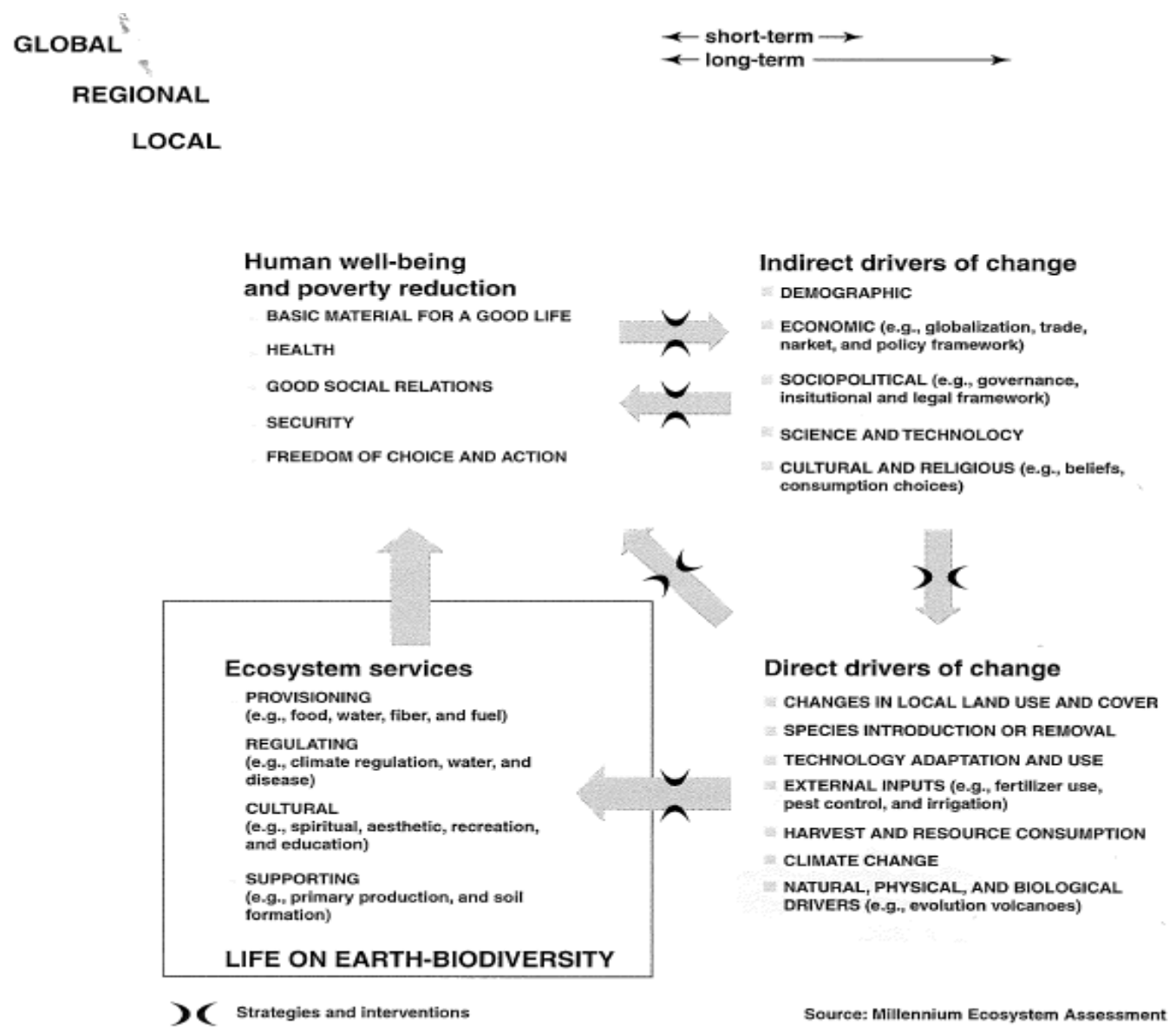

Figure 1: MA conceptual framework (MA, 2005b)

For MA did not provide a sufficient guide on economic aspects of ecosystem services, a new global study entitled "The Economics of Ecosystems and Biodiversity" (TEEB) was initiated to focus particular attention to the economic valuation of ecosystem services. In TEEB (2010) ecosystem services are defined as the direct and in direct contributions of ecosystems to human well-being, which makes a clear distinction between services and benefits and explicitly acknowledges that ecosystem services can benefit people in direct and indirect ways. TEEB identifies four types of ecosystem services: provisioning, regulating, cultural and amenity, and habitat. The supporting services such as soil formation and primary production are omitted because they are seen in TEEB as regulating services. Instead, the habitat services 
are identified separately to highlight the importance of ecosystems to provide habitat for migratory species and gene-pool protection (Table 1).

Table 1: Classification of ecosystem services in MA and TEEB (based on MA, 2005a and TEEB, 2010)

\begin{tabular}{|c|c|}
\hline MA & TEEB \\
\hline Provisioning Services & Provisioning Services \\
\hline Food & Food \\
\hline Fresh water & Water \\
\hline Fiber & Raw materials \\
\hline Fuel & \\
\hline Genetic resources & Genetic resources \\
\hline $\begin{array}{l}\text { Biochemicals, natural medicines, } \\
\text { pharmaceuticals }\end{array}$ & Medicinal resources \\
\hline Ornamental resources & Ornamental resources \\
\hline Regulating Services & Regulating Services \\
\hline Air quality regulation & Air quality regulation \\
\hline Climate regulation & Climate regulation \\
\hline Water regulation & Regulation of water flows \\
\hline Water purification and waste treatment & Waste treatment \\
\hline Erosion regulation & Erosion prevention \\
\hline Natural hazard regulation & Moderation of extreme events \\
\hline Disease regulation & $\begin{array}{l}\text { Maintenance of soil fertility, soil formation and } \\
\text { nutrient cycling }\end{array}$ \\
\hline Pest regulation & Biological control \\
\hline Pollination & Pollination \\
\hline Cultural Services & Cultural and Amenity Services \\
\hline Cultural diversity & \\
\hline Spiritual and religious values & Spiritual experience \\
\hline Knowledge systems & \\
\hline Educational values & Information for cognitive development \\
\hline Inspiration & Inspiration for culture, art and design \\
\hline Aesthetic values & Aesthetic information \\
\hline Social relations & \\
\hline Sense of place & \\
\hline Cultural heritage values & \\
\hline Recreation and ecotourism & Opportunities for recreation and tourism \\
\hline Supporting Services & Habitat Services \\
\hline $\begin{array}{l}\text { Soil formation } \\
\text { Photosynthesis } \\
\text { Primary production } \\
\text { Nutrient cycling } \\
\text { Water cycling }\end{array}$ & $\begin{array}{l}\text { Maintenance of life cycles of migratory species } \\
\text { Maintenance of genetic diversity }\end{array}$ \\
\hline
\end{tabular}


TEEB (2010) distinguishes ecosystem services from ecosystem functions, which depend on ecosystem structure and process. It further makes a distinction between ecological, sociocultural and economic benefits and values. How to balance these values is the problem of decision-makers at any level, whose behaviors influence many factors, which in turn, both directly and indirectly, affect ecosystems. Based on these assumptions TEEB presents its conceptual framework (Figure 2).

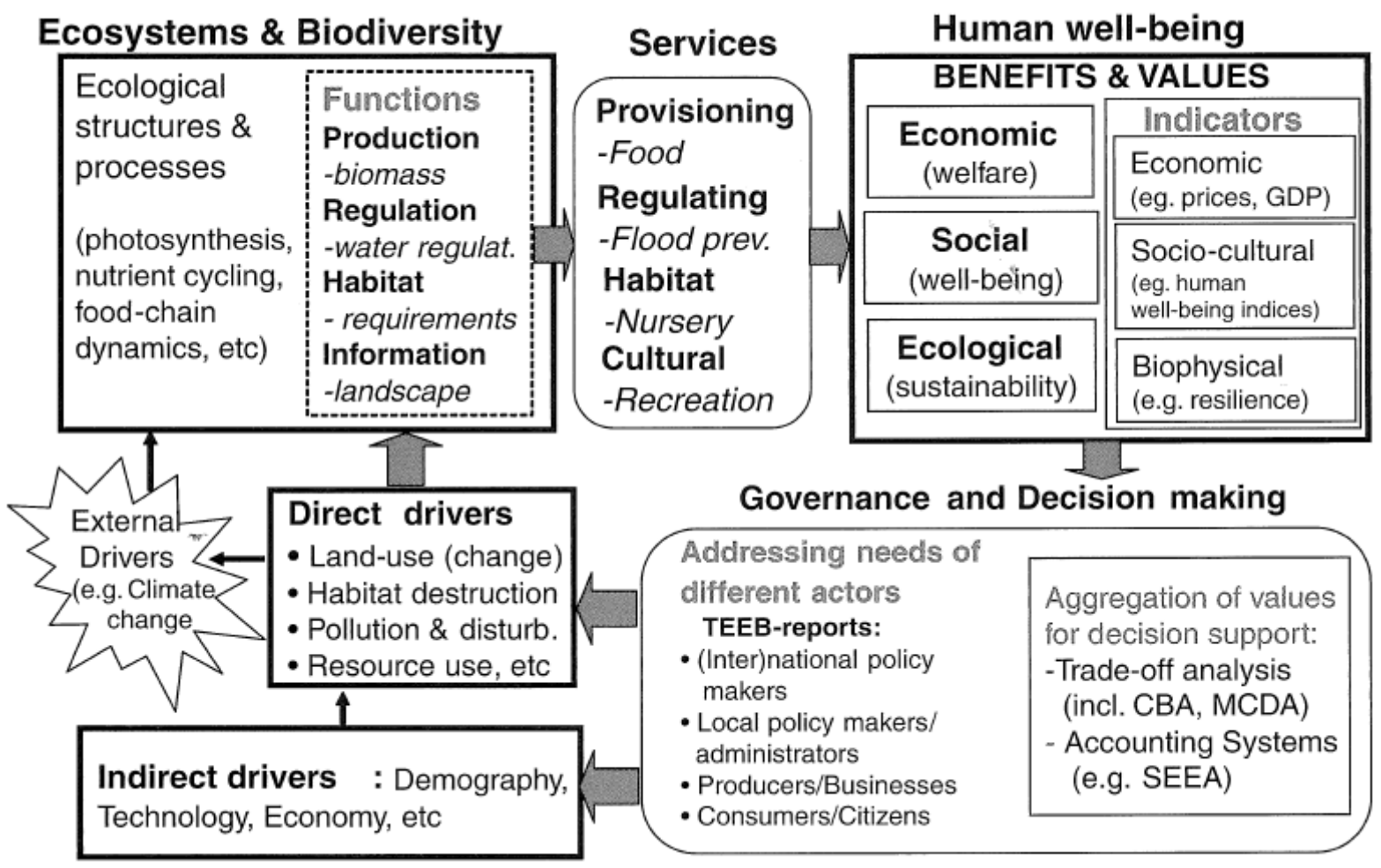

Figure 2: TEEB conceptual framework (TEEB, 2010)

On the basis of the distinction of ecosystem functions and services, we argue that the supporting services defined in MA are actually ecosystem functions. According to the definition of $\mathrm{CBD}$, biodiversity is variability among living organisms from all sources including, inter alia, terrestrial, marine and other aquatic ecosystems and the ecological complexes of which they are part: this includes diversity within species, between species and 
of ecosystems (United Nations, 1992). Thus, biodiversity and ecosystem are closely related concepts: biodiversity is a structural feature of ecosystem, while the variability among ecosystems is an element of biodiversity. For this reason, we argue that the habitat services defined in TEEB is not appropriate either. By comparing the similarities and differences of the ecosystem services classifications in MA and TEEB, we suggest our classification (Table 2).

Table 2: Classification of ecosystem services

\begin{tabular}{|l|l|l|}
\hline Provisioning Services & Regulating Services & Cultural Services \\
\hline Food & Climate regulation & Sense of place \\
\hline Water & Air quality regulation & Cultural heritage \\
\hline Raw materials & Water flows regulation & Spiritual and religious \\
\hline Genetic resources & Water purification and waste treatment & Inspirational \\
\hline Medicinal resources & Erosion regulation & Aesthetic \\
\hline Ornamental resources & Biological control & Educational \\
\hline & Pollination & Recreation and tourism \\
\hline & Natural hazard regulation & \\
\hline
\end{tabular}

Now we propose a refined conceptual framework (Figure 3), starting with a series of definitions. Following MA and TEEB, we adopt the definition of ecosystem in the Convention on Biological Diversity. Further, we suggest explicitly ecosystem component as the base of an ecosystem.

- Ecosystem: A dynamic complex of plant, animal and micro-organism communities and their non-living environment interacting as a functional unit (United Nations, 1992).

- Ecosystem component: Individual species of plant, animal and micro-organism and the abiotic stuff such as sunlight, air and water.

- Ecosystem structure: The biophysical architecture of an ecosystem made up by ecosystem components (modified on TEEB, 2010). 
- Ecosystem process: Any change or reaction caused by ecosystem components and structures which occurs within an ecosystem, either physical (e.g. water infiltration, sediment movement), chemical (e.g. reduction, oxidation) or biological (e.g. photosynthesis, primary production) (modified on TEEB, 2010).

- Ecosystem function: A subset of the interactions between ecosystem components, structures and processes that underpin the capacity of an ecosystem to provide services, e.g. soil formation, nutrient cycling and water cycling (modified on TEEB, 2010).

- Ecosystem service: The direct and indirect contributions of ecosystems to human wellbeing (TEEB, 2010).

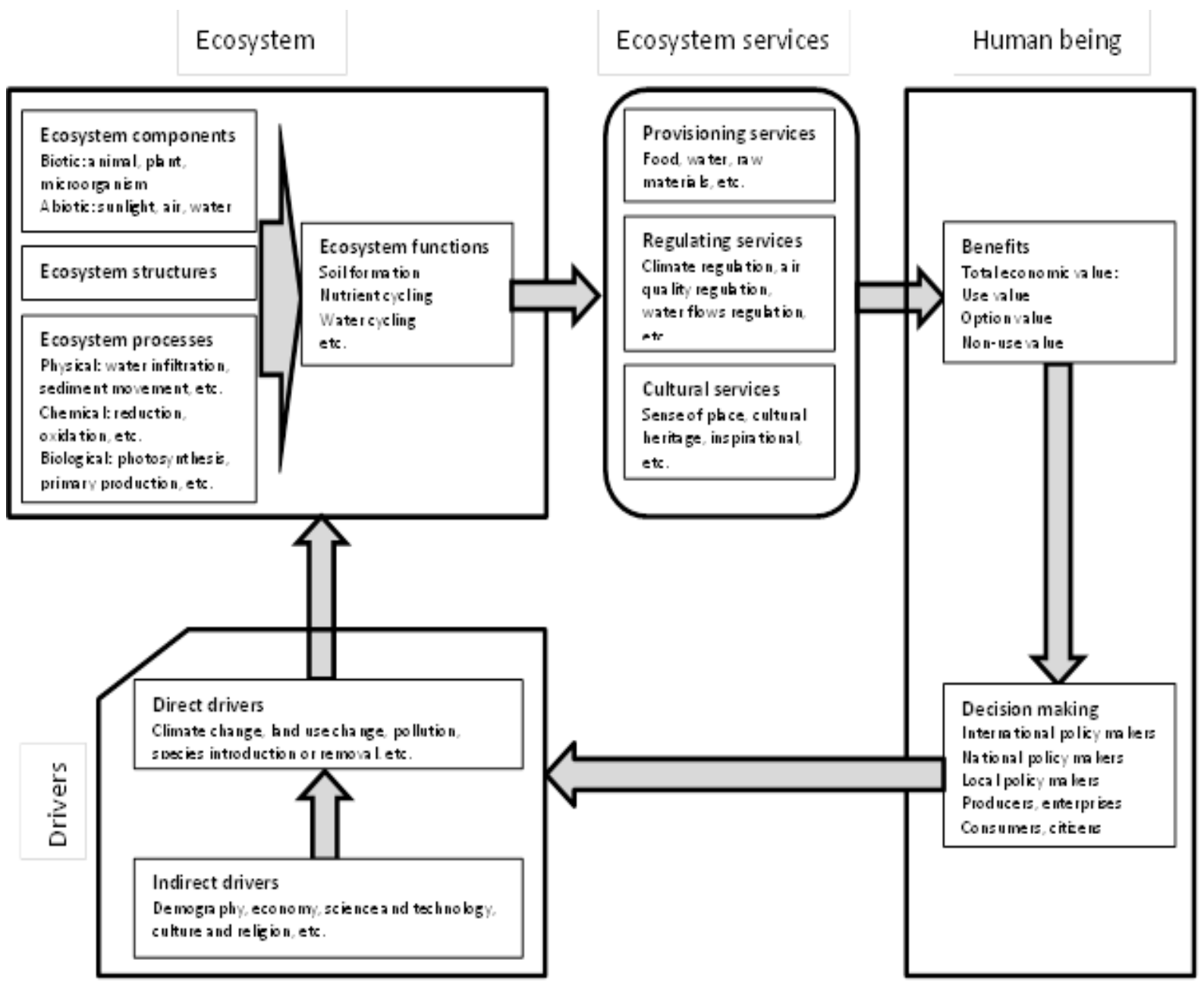

Figure 3: Conceptual framework for linking ecosystems and human being 
We use the term "human being" instead of "human well-being" for the reason that people not only benefit from ecosystem services (well-being) but also make decisions based on these benefits, which in turn influence ecosystems through direct and indirect drivers. We do not distinguish between benefit and value, because benefits implicate the value of ecosystem services and the valuation of the benefits is the target of environmental or ecological economics. For the valuation of the benefits contributed by ecosystem services the concept of total economic value plays a central role (Table 3).

Table 3: The concept of total economic value connected with ecosystem services

\begin{tabular}{|c|c|c|c|c|}
\hline & \multicolumn{2}{|c|}{ Value type } & Meaning & Ecosystem services \\
\hline \multirow{6}{*}{$\begin{array}{l}\text { Total } \\
\text { Economic } \\
\text { Value }\end{array}$} & \multirow{2}{*}{$\begin{array}{l}\text { Use } \\
\text { values }\end{array}$} & $\begin{array}{l}\text { Direct use } \\
\text { value }\end{array}$ & $\begin{array}{l}\text { Derived from direct human use of } \\
\text { ecosystems (consumptive and non- } \\
\text { consumptive) }\end{array}$ & $\begin{array}{l}\text { Provisioning and } \\
\text { cultural services }\end{array}$ \\
\hline & & $\begin{array}{l}\text { Indirect use } \\
\text { value }\end{array}$ & Derived from the regulating services & Regulating services \\
\hline & \multicolumn{2}{|c|}{ Option value } & $\begin{array}{l}\text { Derived from the importance that people } \\
\text { give to the future availability of } \\
\text { ecosystem services for personal benefits }\end{array}$ & $\begin{array}{l}\text { Provisioning, } \\
\text { regulating and } \\
\text { cultural services }\end{array}$ \\
\hline & \multirow{3}{*}{$\begin{array}{l}\text { Non-use } \\
\text { values }\end{array}$} & $\begin{array}{l}\text { Bequest } \\
\text { value }\end{array}$ & $\begin{array}{l}\text { Attached to the fact that future } \\
\text { generations will have access to the } \\
\text { benefits from species and ecosystems } \\
\text { (intergenerational equity concerns) }\end{array}$ & \multirow{3}{*}{ Cultural services } \\
\hline & & $\begin{array}{l}\text { Altruist } \\
\text { value }\end{array}$ & $\begin{array}{l}\text { Attached to the fact that other people of } \\
\text { the present generation have access to the } \\
\text { benefits from species and ecosystems } \\
\text { (intragenerational equity concerns) }\end{array}$ & \\
\hline & & $\begin{array}{l}\text { Existence } \\
\text { value }\end{array}$ & $\begin{array}{l}\text { Attached to the fact of the mere } \\
\text { knowledge that species and ecosystems } \\
\text { continue to exist (non-anthropocentric } \\
\text { concerns) }\end{array}$ & \\
\hline
\end{tabular}

As a widely used decision making tool which plays an important role in TEEB, however, the history of cost-benefit analysis has long been neglected. This dissertation begins with the origin and early development of cost-benefit analysis to see whether this analytical tool is still suitable in the current context of the economic valuation of ecosystem services. The second paper further concerns the historical development of the non-market environmental valuation 
methods and the concept of total economic value, which initiated in the context of cost-benefit analysis for valuing environment and recreation. After tracing out the history of cost-benefit analysis and valuation methods, we apply the principal of cost-benefit analysis and the costbased valuation methods with an additional ecological perspective to a case study of riparian forest in the floodplain ecosystem to show how this tool can be modified and expanded to adapt for the role it can play in the valuation of regulating services. When we finally focus on cultural services of a river ecosystem, the Weser River in Germany, we find out that economic valuation of these intangible services is almost impossible except for the recreational service. Nevertheless, we still try to assess them in a qualitative way, hoping that a kind of economic valuation method can be found based on our findings.

\section{References}

Millennium Ecosystem Assessment (MA) (2005a): Ecosystems and human well-being: Synthesis. Washington, DC: Island Press.

Millennium Ecosystem Assessment (MA) (2005b): Ecosystems and human well-being: Current State and Trends. Washington, DC: Island Press.

TEEB (2010): The economics of ecosystems and biodiversity: Ecological and economic foundations. London: Earthscan.

United Nations (1992): Convention on Biological Diversity. 


\section{Paper 1: The origin of cost-benefit analysis: a comparative view of France and America}

\section{Introduction}

Cost-benefit analysis (CBA) is a decision-aiding tool that quantifies in monetary terms the value of all consequences associated with a government policy (such as setting an environmental standard) or with an investment project (such as reforestation in a floodplain) to all members of society. The purpose of CBA is to help social decision making and to allocate scarce resources more efficiently. Currently, CBA is widely used in government departments, in environmental agencies, and among various progressive interest groups (Hanley and Barbier, 2009; Boardman et al., 2011).

However, noting that there are few researches engaging particularly in the history of CBA, the historical development of CBA has long been subject to overt neglect. Although CBA has been developed into a complete technique for measuring economic efficiency, not only including a variety of valuation methods, but also taking discount in the future, uncertainty and ethic perspectives into account, it was considered as a simple comparison of costs and benefits at its very beginning. In this sense of CBA there are three opinions about its origin in the literature. Most of researchers take the position that CBA first emerged in the United States during the 1930s (e.g. Hanemann, 1992; Hufschmidt, 2000). Hanley and Spash (1993) were the first, and Boland et al. (2009) followed, to claim earlier origin with US Secretary of the Treasury, Albert Gallatin, in 1808. And, Pearce (1998) and Pearce et al. (2006) attributed its origin to the work of Jules Dupuit in 1844. This means that the early stage of CBA passed in France and America. Regarding how to calculate costs and benefits the French engineers and the American professionals traveled different ways. This paper attempts to trace out the 
origin of CBA and the early development of calculation methods in France and America, respectively.

\section{The origin and development in France}

Due to the facts that there are not many English studies dealing with the contributions of French engineers to CBA and that the work of Ekelund and Hébert (1999) on this subject was widely acknowledged, this section relies on their previous research to a great degree. We retrace their steps in a more brief and chronological way. The idea of a national transportation network in France began in the seventeenth century, since when French engineers worked consciously at introducing a decision rule to guide the construction of public works. The earliest demands depended on French engineers by military considerations, the most prominent engineer of this era was Sébastien Vauban, whose key role was associated, rather than to his talent for economic calculation, to his formative influence on the Corpes des Ingénieurs des Ponts et Chaussées, which was instituted in 1716. A central office within the Corps was established in 1747 for the purpose of training more men and improving their effectiveness, it gradually evolved into the École des Ponts et Chaussées in 1775 and was renamed the École Nationale des Ponts et Chaussées (ENPC) after the Revolution. At the ENPC mathematics was highly appreciated, courses were also, of course, given in the engineering subjects of road, bridge and canal building, flood control, harbor improvement, and railroad construction, and economic studies were incorporated into coursework early on. In the first half of the nineteenth century the graduates of the ENPC have been a well-trained group, referred to as Ponts engineers, who developed some fundamental principles and analytical tools to solve cost-benefit calculations of the construction of public works. Jules 
Dupuit was the culmination among those brilliant engineers in this field (Porter, 1995; Ekelund and Hébert, 1999).

\subsection{The pre-revolutionary period}

The first formal cost-benefit study was undertaken in 1708 by the Abbé de Saint-Pierre in considering measuring the incremental benefits of road improvements. He theorized that incremental benefits would result from increased trade and reduced transport costs. The benefit of increased trade was calculated in two steps. First, the annual value of agricultural output in each province from the annual tax revenue collected was estimated. Then a loss factor, percentage of annual output not produced due to the impossibility of transport, was added to this magnitude. The resulting figure indicated the benefit of increased trade, because this loss would be restored by improving the roads. The benefit of reduced transport costs was calculated by the savings per horse and driver. Assuming that the roads were equally passable in all seasons, horses would be able to carry 20 percent more weight, and more trips could be made, only 80 percent as many horses would be required as before the road improvements, resulting in annual savings of 20 percent fewer horses and drivers. On the cost side, the annual additional expenses consisted of costs for administration, repair and continuing maintenance (Ekelund and Hébert, 1999).

From the very beginning of CBA, Saint-Pierre was sensitive to the use of incremental analysis in evaluating public goods. He was also alert to the indirect of secondary benefits by observing that better roads could attract industry and trade, which in turn could increase employment. Additionally, he was well aware that this kind of analytical techniques could be fruitfully applied to all public works. Saint-Pierre framed the important issue that was to face 
generations of Ponts engineers, and his argument was accepted by at least one prominent engineer of the newly formed Corps, Hubert Gauthier. However, his early cost-benefit calculations were separated from those undertaken by the Ponts engineers for reasons that are not clear (Ekelund and Hébert, 1999).

The era of canal construction in prerevolutionary France gave the engineers the possibility to turn their cost-benefit calculations to greater effect, because the benefits and costs of canals are more precisely economic and more susceptible to measurement. However, due to technical and financial difficulties, the wave of canal construction failed to stimulate much analytical progress. A project for constructing a canal must be certified by engineers according to the public utility of the canal, but the engineers at that time did not understand the concept of demand. Benefits could neither be calculated by increased trade nor by reductions in transport costs, because no trade had existed before. Therefore, benefits were identified chiefly in terms of value of time saved in the shipment of goods, which was notoriously difficult to deal with. For these difficulties two decision rules emerged eventually with regard to canals. First, a canal produced net utility when the resulting savings in transport costs were greater than its construction costs, and second, a canal adds utility when, treating construction costs as sunk, its toll revenues exceed its maintenance costs. But the appropriate level of tolls posed another vexing problem because any levy reduced the public utility of canals (Ekelund and Hébert, 1999).

\subsection{The revolutionary period}

The revolutionary spirit made all past institutions suspect, including the Corps and the École, so that the old regulations in relate to public works were in part abolished, in part abandoned, 
and altogether dependent on local conditions. After ascending to power Napoleon Bonaparte helped restore order to the administration of the Corps and began to assign many new projects, most of which were driven by political or military considerations. He was mainly concerned with cost and speed of project construction, therefore, the engineers' attention was focused understandably on cheapness and expediency rather than on calculating expected benefits. The problem of minimizing transport cost had been solved mathematically by Gaspard Monge in 1776 , but this was not a complete solution to the problem at hand because it shed no light on the issue of benefits. It is just on the benefit side that real progress should be made (Ekelund and Hébert, 1999).

\subsection{The post-revolutionary period}

The engineers were recentralized in the Ministry of the Interior during the Restoration, making a fertile period in economic analysis from the 1820 s to 1840 s. The stimulus given to canal construction prompted a number of minor advances in the formulation of CBA. In 1824, focusing on the value of time saved in transport and the amortized costs of building and maintaining a canal, Pierre-Simon Girard tried to measure the benefit of the canal in physical terms by employing a curious combination of hydraulics and economics. The shortcomings of his method were demonstrated by Louis-Joseph Favier in 1824, who established the principle that a public work could be justified when it conveyed positive net utility, that is, the amount of net revenue from the public work must be greater than the cost of (re)construction, disregarding how the revenues and costs were assigned. To emphasize the choice between alternative public investments Favier derived a rule stating that a public work is to be preferred if its net utility exceeds that of another, taking into account the life of the respective constructions and amortized costs (Ekelund and Hébert, 1999). 
As early as 1830, a prominent Ponts engineer named Henri Navier set up a cost-benefit principle that public works should be provided only if the total benefits exceeds the total costs by attempting to measure the benefits of new transport facilities through an estimate of cost savings. His effort produced a decision rule that allowed for calculating minimum demand for new public works, below which the construction would be against the interests of the state. Algebraically, Navier defined the annual recurrent costs related to a new canal $(C)$, the price of goods transported by road $(r)$, the price of goods transported by canal $(c)$, cost savings to consumers attributable to the canal $(S=r-c)$, and the annual amount of goods transported on the new canal $(n)$. Since $\mathrm{n}$ is a function of $\mathrm{S}$, there must be some $\mathrm{n}^{\prime}$ and $\mathrm{S}$ ' such that $n^{\prime} S^{\prime}=C$, so $n^{\prime}$ is the minimum demand being sought. If $n>n$, the state would gain annually a net amount equal to $S *\left(n-n^{\prime}\right)$, while if $n<n^{\prime}$, the state would lose annually a similar amount (Ekelund and Hébert, 1973, 1978, 1999).

Joseph Minard, who was an important link between Navier and Dupuit in the development of CBA, made two major advances to Navier's analytical framework in 1832. First, he recognized that utility-increasing cost savings resulted from changes in consumption by inducing old consumers to substitute the lower-priced good for other goods and by drawing into the market new consumers who could not afford the good before. When new consumers entered the market, the utility gained by society would depend on consumers' reaction to this price change, which in turn would depend on the consumers' income. Second, in comparison to Navier, Minard introduced more subjective elements into the measure of benefit. A unique one was his explicit treatment of time. He insisted that time must be given a value, and that failure to take into account the benefits from time saved would lead to systematic underestimate of social benefit. However, he was clearly aware of the difficulty to evaluate 
the time, and he overcame this hurdle by assigning a subjective monetary value to the time, for example using wages as the opportunity cost of a worker's time (Ekelund and Hébert, 1973, 1978, 1999).

In 1833, Charlemagne Courtois developed a single principle for the selection of the most preferable transport project linking two cities. That is to choose the project that, given the costs, provides the greatest benefit. To identify the benefit of a project, Courtois singled out as relevant variables the amount of goods in tons $(n)$, the transport costs per ton and kilometer $(p)$, the distance of the route $(l)$, a sum of outlay $(A)$, and the construction and maintenance costs $(C)$. His analysis distinguished between communications already existed and new ones to be established. In the first case, he argued that the most preferable project should be the one over which, for a given outlay $A$, the greatest amount of goods could be carried. Since $A=n l p$, he took $n=A / l p$ as the typical form of the solution and concluded that to the least product of $l$ and $p$ would correspond the greatest value of $n$, and consequently the most preferable project. In the second case, the construction and maintenance costs should be taken into account. Courtois introduced the ratio of the amount of goods carried per unit of construction and maintenance cost under each project as the benefit criterion which he called "the measure of advantages". He took $n / C=A / C l p$ as the typical form to determine the character of the project with the maximum of advantages (Theocharis, 1988; Ekelund and Hébert, 1999).

André Mondot de Lagorce adopted and improved these considerations by more rigor and generality in 1840 . He treated costs more sophisticatedly by normalizing annual maintenance costs in terms of the average costs of labor and materials, and he was keenly aware of the difference between the interest rate as a cost of capital and the discount rate used to reduce 
future expenditures to present value. Mondot realized that a full solution required estimating transport demand on the new route, and admitted that it was impossible to determine the exact demand a priori, because demand depended on the choice of projects, which was the solution being sought. But he refused to abandon economic calculation, insisting that the estimation of demand, despite imperfect, was better than arbitrary decision. On the cost side, Mondot defined the construction costs $(c)$, the annual maintenance costs $(d)$ normalized according to average costs of labor and materials, the appropriate discount rate $(r)$, and the annual savings in maintenance costs on the old road $(S)$ owing to less traffic after the new road is built. Thus, the annual expense of the new road $(C)$ is equal to $c r+d-S$. On the benefit side, he defined the average transport cost on the new road $(p)$ calculated as a function of weight, the average transport cost on the old road $(q)$, and the estimated amount of goods to be transported on the new road $(n)$. Thus, the total benefit of the new road $(B)$ is equal to $n(q-p)$. For the value $n$ was not given, Mondot proposed the measure of "the real utility per unit of expenditure", which is equal to $(q-p) / C$, as "the administrative value" of a project. What he called a "normal project" was the one with the highest "administrative value". Mondot's work typified the simple definition of CBA by proposing a criterion that compared disadvantages $(C)$ with advantages $(B)$. So long as a large number of projects were desirable, rigorous estimate of transport demand $(n)$ on new routes was not always a pressing problem, for one could simply reject all projects for which $B-C$ was not sufficiently positive (Ekelund and Hébert, 1999).

However, this straightforward approach ignored important demand effects that resulted from the reduction of commodity prices induced by lower transport costs. A more sophisticated solution required a theory of demand. In 1844, Jules Dupuit published his breakthrough article "On the measurement of the utility of public works", not only providing the demand 
function derived from a basic theoretical principle of consumer behavior - marginal utility, but also introducing a practical measure of economic welfare - consumer surplus, which became the theoretical basis of CBA and stood as lasting monuments to the pioneer efforts of the French engineer-economists (Schumpeter, 1955; Ekelund and Hébert, 1999). By raising the question of how the utility of public works was to be measured, Dupuit began with the definitions of utility. Using the examples of wine tax (market good) and water system in a town (public works), he came to the conclusion that "each consumer himself attaches a different utility to the same thing according to the quantity which he can consume". Thus he succeeded to unravel the Smith-McCulloch dichotomy of value. Then he distinguished between the absolute utility and the relative utility. "In general the relative utility of a product is expressed by the difference between the sacrifice which the purchaser would be willing to make in order to get it, and the purchase price he has to pay in exchange", supposing that the market price of the product is more or less equivalent to the costs of production. Although Dupuit did not identify the exact concept of marginal utility, he did illustrate the idea from an empirical consideration that Ponts engineers typically confronted, and concluded that "in general every rise of fall in price decreases or increases utility by an amount equal to this variation for those who are consumers in both situations; for those who disappear or who appear, the utility lost or acquired is equal to the old or to the new relative utility yielded to them by the product" (Dupuit, 1844; Ekelund and Hébert, 1976; Mosca, 1998).

By pointing out the error in Navier-Say's calculation of the utility of a canal, Dupuit proposed his method, arguing that the measure of utility for products already being consumed should be based on reduction in costs of production rather than reduction in costs of transportation, while in the case of new commodities being transported the measure of utility would be the 
lowest tax which would prevent their being carried by the new route. In order to calculate operationally the utility of public works, Dupuit derived his "consumption curve", which was actually the marginal utility curve (Figure 1). He defined the "consumption curve" as $q=f(p)$, thus placing the independent variable (price) on the $x$ axis and the dependent variable (quantity) on the $y$ axis. He showed that the absolute utility of $O q^{\prime}$ articles is equal to the area $O q$ 'n'P under the consumption curve, and derived the relative utility, what is now called consumer surplus, by subtracting the costs of production shown as $O q$ 'n 'p', which leaves the area $n ' p$ 'P. Suppose the price decreases from $p$ ' to $p$ due to a reduction in costs of production, so that the quantity consumed increases from $q$ ' to $q$. This raises the absolute utility to $O q n P$, subtracting costs of production Oqnp from this amount yields the relative utility of $n p P$, so the net gain in relative utility is measured by pnn 'p' (Dupuit, 1844). In this manner Dupuit not only developed a monetary measure of the benefit of public works and of goods in general, but also forged the most important tool of welfare economics. It was a significant breakthrough, but clearly far from perfect.

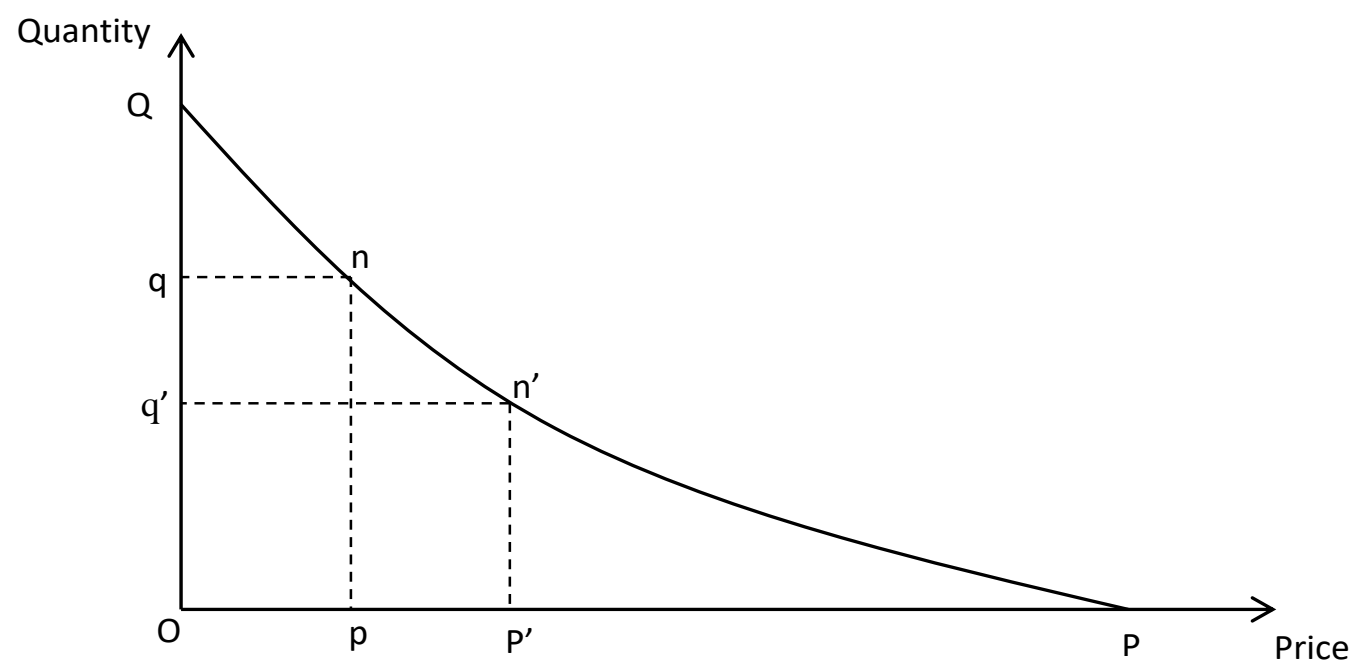

Figure 1: Dupuit's “consumption curve” 
Table 1 summarizes the contributions to CBA made by French econo-engineers. Since the 1850s a railway era began in France, more and more engineers turned their attention to the economics of railroads because of the peculiar cost structure and the unique pricing issues of the railroads. The methods for calculating benefits proposed and improved by the engineers did not form general standards or decision rules that were accepted on the administrative level to value a single project or to justify the choice between rival projects. Until the end of the 19th century the administrative form of economic quantification in project planning was still carried out in terms of cost and revenue, not costs and benefits (Porter, 1995). However, on the other side of the Atlantic, CBA was quietly emerging and would see its real rise in the United States.

Table 1: Contributions of econo-engineers to the development of CBA in France

\begin{tabular}{|l|l|l|}
\hline Year & Person & Contribution \\
\hline 1708 & Abbé de Saint-Pierre & $\begin{array}{l}\text { Theorizing that extra benefit of road improvements is equal to } \\
\text { benefit from increased trade plus benefit from reduced transport } \\
\text { cost minus additional expenses for improvement }\end{array}$ \\
\hline 1822 & Girard & $\begin{array}{l}\text { Measuring the benefit of a canal in terms of the value of time } \\
\text { saved in transport and the amortized costs of building and } \\
\text { maintaining the canal }\end{array}$ \\
\hline 1830 & Navier & $\begin{array}{l}\text { Establishing the principles that the amount of net revenue from } \\
\text { a public work must be greater than the cost of (re)construction, } \\
\text { and that a public work is to be preferred if its net utility exceeds } \\
\text { that of another }\end{array}$ \\
\hline 1832 & Minard & $\begin{array}{l}\text { Setting up the cost-benefit principle that public works should } \\
\text { be provided only if the total benefits in terms of cost savings } \\
\text { exceeds the total costs }\end{array}$ \\
\hline 1833 & Courtois & $\begin{array}{l}\text { Making two advances to Navier's work by recognizing that } \\
\text { savings resulted from changes in consumption and by } \\
\text { introducing the value of time into the measure of benefit }\end{array}$ \\
\hline 1840 & Mondot & $\begin{array}{l}\text { Developing a single principle for the selection of the most } \\
\text { preferable transport project linking two cities by calculating the } \\
\text { greatest benefit given the costs }\end{array}$ \\
\hline 1844 & Dupuit & $\begin{array}{l}\text { Typifying the cost-benefit principle that compares advantages } \\
\text { with disadvantages of a public work }\end{array}$ \\
\hline $\begin{array}{l}\text { Establishing the demand function based on marginal utility and } \\
\text { introducing a practical measure of economic welfare known as } \\
\text { consumer's surplus }\end{array}$ \\
\hline
\end{tabular}




\section{The beginning and rise in America}

The American water resources development, including navigation, flood control, irrigation and water power, initiated from the beginning of the nineteenth century (Viessman, 2009; Griffin, 2012). The Gallatin Report of 1808 proposed partly a nationwide system of canal and river improvements justified on the basis of economic development of the west, political unity and national defense needs, but it had no immediate effect because it was only a statement about the issue of public investment in transportation and far from an economic analysis of individual projects (Holmes, 1972; Hines, 1973).

As the first major construction agency with the requisite technical abilities, the Army Corps of Engineers established officially in 1802 on the model of the Corpes des Ingénieurs des Ponts et Chaussées, was given responsibilities for planning river and harbor improvements through two acts in 1824. The establishment of the Mississippi River Commission in 1879 involved the Corps in flood control. The 1902 River and Harbor Act created a national-level Board of Engineers within the Corps to evaluate construction and maintenance costs, commercial benefits and necessity of river and harbor improvements. The 1917 Flood Control Act introduced the principle of local financial contributions to flood control, and authorized the Corps to undertake comprehensive studies of watersheds regarding the relationship of flood control to navigation, water power and other uses. The 1920 River and Harbor Act further required the reporting of local benefits for the recommendations of appropriate local cost sharing (Holmes, 1972; Arnold, 1988; U.S. Army Corps of Engineers, 2008). American efforts to economic evaluations of public investments during this early era were lack of rigor and depended almost completely on estimate (Hines, 1973; Porter, 1995). The Report on the Chesapeake and Ohio Canal made in 1826 is a representative example (Table 2). 
Tab. 2: Costs and benefits for constructing the Chesapeake and Ohio Canal (modified according to Board of Internal improvement, 1826)

\begin{tabular}{|c|c|c|c|c|}
\hline \multicolumn{5}{|l|}{ Cost } \\
\hline Section & Distance $(\mathrm{km})$ & $\begin{array}{l}\text { Ascent or Descent } \\
(\mathrm{m})\end{array}$ & $\begin{array}{l}\text { Number of } \\
\text { locks }\end{array}$ & Estimated cost (\$) \\
\hline Eastern & 298.7 & 176.2 & 74 & $8,177,081.05$ \\
\hline Middle & 113.6 & 597.7 & 246 & $10,028,122.86$ \\
\hline Western & 137.1 & 188.7 & 78 & $4,170,223.78$ \\
\hline Sum & 549.4 & 962.6 & 398 & $22,375,427.69$ \\
\hline \multicolumn{4}{|l|}{ Benefit } & $\begin{array}{l}\text { Estimated benefit } \\
(\$)\end{array}$ \\
\hline \multicolumn{4}{|c|}{$\begin{array}{l}\text { Augmentation in the value of lands, or benefit derived by owners of } \\
\text { real property }\end{array}$} & $36,780,000$ \\
\hline \multicolumn{4}{|c|}{$\begin{array}{l}\text { Total of successive augmentations of the value of the products } \\
\text { during six years, or advantages obtained by the producers }\end{array}$} & $38,989,560$ \\
\hline \multicolumn{4}{|c|}{$\begin{array}{l}\text { Total of successive augmentations by the revenue of the customs, } \\
\text { during the same period }\end{array}$} & $3,996,195$ \\
\hline \multicolumn{4}{|c|}{$\begin{array}{l}\text { Benefits derived to commerce and the carrying business together, } \\
\text { and for six years }\end{array}$} & $1,859,830$ \\
\hline \multicolumn{4}{|l|}{ Sum } & $81,625,585$ \\
\hline
\end{tabular}

\subsection{The beginning of CBA}

The modern economic analysis of project value began during the New Deal. The most important agency in relation to water resources in this period were four successive national resource planning organizations operating between 1933 and 1943, namely National Planning Board (NPB, 1933-1934), National Resources Board (NRB, 1934-1935), National Resources Committee (NRC, 1935-1939), and National Resources Planning Board (NRPB, 1939-1943) (Clawson, 1981). With the most quoted passage "...if the benefits to whomsoever they may accrue are in excess of the estimated costs..." (United States, 1936), the 1936 Flood Control Act is usually considered as the beginning of cost-benefit analysis in the United States (Hanemann, 1992; Pearce, 1998; Hufschmidt, 2000; Caufield, 2000). However, we claim here that the outstanding report of the NRB in 1934 has the larger authority on the origin of CBA for three reasons. First, like the famous act, this report had a clear statement that "we hope in 
general to achieve rational planning and in particular to achieve equitable allocations of benefits and contributions to cost in public works programs". Second, it identified tangible, measurable intangible, as well as immeasurable benefits. Third, it included substantial economic basis. Additionally, two principal categories of water projects were recognized, one for income producing e.g. hydroelectric power and another for loss preventing e.g. flood control, which implied that prevented tangible and intangible losses are the measure of benefits (National Resources Board, 1934). Nevertheless, the 1936 Flood Control Act still has significant meaning that a strict cost-benefit rule is written into law and hereafter Congress can only, without exceptions, authorize projects that have been studied and approved (Porter, 1995).

The 1938 report of the NRC suggested that social and economic benefits, general and special benefits, potential and existing benefits should be taken into account in deciding whether or not large water projects should be undertaken as well as in distributing the costs of projects among the beneficiaries (National Resources Committee, 1938). The 1941 report of the NRPB further recognized two general categories - tangible and intangible - of benefits and costs as well as two types - primary and secondary - of tangible benefits and costs. It suggested that a project plan was economically sound if total benefits were greater than total costs, and benefits from each function of multiple-purpose projects were greater than separable costs incurred solely in serving that function (National Resources Planning Board, 1941).

The Water Resources Committee of the NRPB and its predecessors contributed greatly to the development of cost-benefit analysis as applied to water projects. Although much of its 
contribution was not highly technical and far less than complete (Clawson, 1981), the committee's works were so basic and influential that they would consistently find retrospective in the postwar history of CBA. However, cost-benefit analysis itself was only an administrative device owing nothing to economic theory in this initial phase (Hammond, 1960) and did not become the principal basis for project evaluations of related agencies until the 1950s.

\subsection{The issuing of the Green Book}

Besides the Corps, there were many other agencies involved in water resources development, however, each agency adopted different and inconsistent methods of estimating costs and benefits. The 1941 report drew attention to these inconsistencies and advocated cooperative studies to develop uniform methods. After the NRPB was abolished in 1943, a new pattern of coordination arose with the establishment of the Federal Interagency River Basin Committee (FIARBC). In 1946 a subcommittee on benefits and costs was appointed "for the purpose of formulating mutually acceptable principles and procedures for determining benefits and costs for water resources projects". This subcommittee issued a final report entitled "Proposed Practices for Economic Analysis of River Basin Projects" in 1950, which became known affectionately among water analysts and cost-benefit economists as the Green Book (Holmes, 1972; Porter, 1995).

The Green Book is recognized as the first landmark in the history of CBA in the United States (Holmes, 1972; Hufschmidt, 2000). Cost-benefit analysis covered completely for the first time its modern subjects, including definition of benefits and costs, general procedure for the measurement, consideration of available alternatives, criteria for comparing alternatives, 
choice of discount rate, risk allowances, and economic life of projects. One of the strengths of the Green Book lies in stating the basic principles of microeconomics, although not in highly theoretic terms. It stated that the ultimate aim of water resources development projects is to satisfy human needs and wants by providing goods and services, which refer to all objects and activities which have the power of satisfying human wants and which may be increased or decreased in availability as a result of a project. It was aware of the limitations of the market price system in reflecting values of goods and services from a public viewpoint, but concluded that there is no more suitable framework for evaluating public projects in common terms. Therefore, market prices had to be chosen as the starting point for measuring the tangible effects of a project, whether benefits or costs. Some tangible effects that cannot be assessed based on market prices may be derived indirectly from prices for analogous effects or from the most economical costs of producing similar effects by an alternative means (FIARBC, 1950).

Another advantage of the Green Book is to apply these principles to develop workable procedures for quantifying benefits of various project purposes, such as irrigation, flood control, navigation, electric power, and recreation, although not in sufficient detail to serve as a manual. For example, the primary benefits of flood control should either be measured in terms of the estimated costs that would be avoided with flood control but would be incurred without it, or be evaluated as the costs of repairing or rehabilitating the affected property. Measuring primary benefits from water power was based on the costs of equivalent power from the alternative source of power that would most likely be utilized in the absence of the water power (FIARBC, 1950). Here we see the rudiments of all cost-based methods that are used widely today, namely avoided cost method, restoration cost method, and replacement 
cost method. Unfortunately, the Green Book argued that the benefits of navigation improvements were measured by savings in transportation costs rather than reduction of production costs, which was Dupuit's main point before one hundred years. For the purpose of evaluating recreational benefits, the Green Book mentioned two approaches being used at that time: recreational benefits were assumed either to be equal to the sum of expenditures by recreationists for items like gasoline, lodging and equipment (expenditure approach), or be equal to the costs of installing, operating and maintaining specific recreational facilities plus an equal amount considered to be the value of the benefits attributable to recreational use of facilities provided for purposes other than recreation, meaning that recreation benefits were equal to twice the specific costs (twice-cost approach). In 1954 the FIARBC was reorganized as the Interagency Committee on Water Resources (IACWR) with a Subcommittee on Evaluation Standards which republished the 1950 report with minor revisions in 1958 (IACWR, 1958).

\subsection{The Bureau of Reclamation and the Bureau of the Budget}

Although the Green Book had considerable influence, it failed utterly to reconcile the costbenefit practices of the relevant agencies, especially the Bureau of Reclamation (BOR). The BOR, established by the Reclamation Act in 1902 for the purposes of making examinations and constructing irrigation works, was the most important rival agency against the Corps in this field. Since the BOR was the specialist on irrigation, it created a set of discrepant methods for quantifying the benefits of irrigation, which contained extravagant measures of indirect benefits. Possibly because the BOR was not involved in preparing the Green Book, the report took gentle but clear position against the Bureau on the issue of secondary benefits, stating that secondary benefits should only be considered under certain strict conditions. It 
was no surprise that the BOR did not accept these restrictions (Porter, 1995; Hufschmidt, 2000). In order to help resolve this issue, the BOR called on a Panel of Consultants to indicate the adequacy of existing procedures for evaluating secondary benefits, and to set forth a recommended basis for their evaluation. The report of the Panel in 1952 stated that secondary benefits are much less determined and measurable than primary, and depend more on farreaching hypotheses. Usable formulas cannot be based on data that are capable of affording accurate and complete comparisons of effects with and without a given project. Thus, it recommended that primary and secondary benefits be separately shown in benefit-cost ratios (Clark et al., 1952).

Beginning in 1943, the Bureau of the Budget (BOB) was required to review and consolidate all public works including water resources projects. Attempting to supervise agency methods for economic justification of projects, the BOB in 1952 issued Budget Circular A-47, which was in many respects similar to but more restrictive than the Green book, to set forth uniform standards and procedures in reviewing proposed water resources project reports (Holmes, 1972; Porter, 1995). Budget Circular A-47 based the evaluation mainly on primary benefits, and provided that not only must the total benefits of a project exceed its costs, but the benefits attributable to any purpose of a multi-purpose project must exceed the costs of including that particular purpose. Additionally, it proposed clearly for the first time that increases in the values of recreation and fish and wildlife resources as a result of the project were a category of primary benefits to be included in evaluation (Bureau of the Budget, 1952). 


\subsection{Takeover by the economists}

As shown clearly above, the early work on water resources evaluation until the early 1950 s was undertaken by professionals from federal agencies (Table 3). Many of these professionals had had a bureaucratic as well as training identity that they worked in the Bureau of Agricultural Economics. However, academic economists relevant to CBA outside the bureaucracy did not almost exist in the early 1950s. There was very few papers published in economic journals on the economics of public investments, and the work of these agricultural economists on the benefits of public works was more closely related to a bureaucratic discourse than an academic one (Porter, 1995; Hufschmidt, 2000; Banzhaf, 2010).

Tab. 3: Contributions of federal guidelines to CBA in America

\begin{tabular}{|c|c|c|}
\hline Year & Document & Contribution \\
\hline 1826 & $\begin{array}{l}\text { Report on the Chesapeake and Ohio } \\
\text { Canal }\end{array}$ & $\begin{array}{l}\text { Providing the typical analysis approach based } \\
\text { on estimate for public investment }\end{array}$ \\
\hline 1934 & Report of National Planning Board & $\begin{array}{l}\text { Marking the beginning of cost-benefit analysis } \\
\text { in America }\end{array}$ \\
\hline 1936 & Flood Control Act & Writing the strict cost-benefit rule into law \\
\hline 1950 & $\begin{array}{l}\text { Proposed practices for economic } \\
\text { analysis of river basin projects (the } \\
\text { Green Book) }\end{array}$ & $\begin{array}{l}\text { Covering all subjects of modern CBA, } \\
\text { establishing all cost-based methods for } \\
\text { measuring benefits }\end{array}$ \\
\hline 1952 & $\begin{array}{l}\text { Report of Panel of Consultants to the } \\
\text { Bureau of Reclamation }\end{array}$ & Discussing the issue of secondary benefits \\
\hline 1952 & Budget Circular A-47 & $\begin{array}{l}\text { Including recreation as a category of primary } \\
\text { benefits }\end{array}$ \\
\hline
\end{tabular}

Along with the consolidation of welfare economics in the 1950s (Little, 1950; Graaff, 1957), CBA became quickly an attractive area for academic economists since the late 1950s. Two important institutions during this period, the Harvard Water Program and the RAND Corporation in California, generated an extensive literature of systematic studies (Eckstein, 1958; Krutilla and Eckstein, 1958; McKean, 1958; Hirshleifer et al., 1960; Maass et al., 1962). Taken together, these books set a sound microeconomic and related welfare economic foundation for the theoretical and applied aspects of CBA. The various market-based 
valuation methods introduced in the Green Book were firmly established. In addition, some difficult conceptual issues such as externalities, opportunity costs, consumer surplus, and secondary benefits that were not familiar to or had troubled earlier practitioners were discussed and clarified (Hanemann, 1992; Hufschmidt, 2000).

In the 1960s the applications of CBA had widened from water resource projects to almost all kinds of government activity, such as public health (Weisbrod, 1961), transportation (Mohring, 1961), education (Bowman, 1962) and urban renewal (Rothenberg, 1965). By this time, CBA had become not only a standard tool for the analysis of government expenditures, but also a legitimate branch of welfare economics (Hanemann, 1992; Porter, 1995). A still more significant breakthrough made by economists lies in the attempt to value recreational benefits, which leads to the flourishing developments of various environmental valuation techniques.

\section{Conclusion}

The elaboration above implicates that the origin and development of CBA in France and America is independent. In the narrow sense of simple comparison of costs and benefits, CBA originated from the study of Saint-Pierre in 1708 and became ripe until Dupuit introduced the concept of consumer's surplus, which founded the economic basis of CBA and measured benefits in terms of the reduction of production costs. In America the origin of CBA can be traced back to the 1934 report of the National Resources Board and the Green Book marked the mature of CBA by establishing cost-based methods for measuring benefits. 
The independence can be further reasoned in four aspects. First of all, there is no considerable evidence suggesting that the American experts are familiar with the early works of French econo-engineers. Although Charles Ellet Jr., an American civil engineer, indeed traveled to Paris in 1830 to study as an external student at the École des Ponts, his contributions to the economic thought lie mainly in the practical problem of monopoly profit maximization of a railroad rather than CBA (Porter, 1995; Ekelund and Hébert, 1999). The cost-benefit criterion proposed by Navier and Mondot finds no mention in the American documents. And the Green Book published in 1950 still considered the benefits of navigation improvements as savings in transportation costs rather than reduction of production costs.

Second, the backgrounds for introducing CBA in France and America are clearly different. The American tradition was related to water resources projects, whereas the French tradition rooted in the field of transport economics. Third, the personnel who made efforts to CBA are also distinct, econo-engineers with formal academic background in France and professionals working in federal agencies in America. Therefore, as Kranakis (1997) points out, the divergence of the approaches they used to develop CBA is significant. French econoengineers tended to take a theoretical approach and attached great importance to mathematical calculation, whereas American professionals adopted an empirical approach and payed more attention to practice. This difference in approaches led reasonably to the theoretical foundation of consumer's surplus in France and practical guidelines of CBA in the United States, respectively.

Finally, the most crucial difference of the development of CBA in France and America lies in the seeking of a certain standardization and uniformization of this method in America, but 
such a progress did not take place in France, at least until the end of 19th century. Porter (1995) saw the political rival situation between agencies with overlapping responsibility as the major driving force for the standardization. In France it was not the case: the French Corps had a strong administrative, institutional and legally acknowledged monopoly position, which prevented the uniformization. Another reason could be the lack of incentive within the powerconscious elites. The active thinking exchange of the econo-engineers through the internal journal generated a variety other than a unity of measurement suggestions. More important, different from the practical considerations of American agencies, for which a pure quantitative economic excess of benefits over costs is necessary and sufficient, French decision-makers at that time also considered unquantifiable variable such as security, reliability, or even promotion of administrative centralization (Henck, 2015).

\section{References}

Arnold, J. L. (1988): The evolution of the 1936 Flood Control Act: Office of History, U.S. Army Corps of Engineers.

Banzhaf, H. S. (2010): Consumer surplus with apology: a historical perspective on nonmarket valuation and recreation demand. In Annual Review of Resource Economics 2.

Board of Internal Improvement (1826): Report on the Chesapeake and Ohio Canal. Washington D.C.

Boardman, A. E.; Greenberg, D. H.; Vining, A. R.; Weimer, D. L. (2011): Cost-benefit analysis. Concepts and practice. 4. ed., intern. ed. Boston, Mass.: Prentice Hall.

Boland, J. J.; Flores, N.; Howe, C. W. (2009): The theory and practice of benefit-cost analysis. In Clifford S. Russell, Duane D. Baumann (Eds.): The evolution of water resource planning and decision making. Cheltenham: Elgar, pp. 82-135.

Bowman, M. J. (1962): Social returns to education. In International Social Science Journal 14 (4).

Bureau of the Budget (1952): Reports and budget estimates relating to federal programs and projects for conservation, development, or use of water and related land resources. Budget Circular A-47. Washington D.C.: U.S.Gov.Printing Office. 
Caufield, H. P., Jr. (2000): Early federal guidelines for water resource evaluation. In Water Resources Update 116, pp. 14-17.

Clark, J. M.; Grant, E. L.; Kelso, M. M. (1952): Report of panel of consultants on secondary or indirect benefits of water-use projects. To Michael W. Straus, Commissioner, Bureau of Reclamation. Washington, D.C.

Clawson, M. (1981): New Deal planning. The National Resources Planning Board. Baltimore: Published for Resources for the Future by Johns Hopkins University Press.

Dorfman, R. (Ed.) (1965): Measuring benefits of government investments. Brookings Institution; Conference of experts. Washington, DC: Brookings Inst.

Dupuit, J. (1844): On the measurement of the utility of public works. In International Economic Papers 2 (1952), pp. 83-110.

Eckstein, O. (1958): Water resource development. The economics of project evaluation. Cambridge: Harvard University Press.

Ekelund, R. B.; Hébert, R. F. (1973): Public economics at the Ecole des Ponts et Chaussees: 1830-1850. In Journal of Public Economics 2 (3), pp. 241-256.

Ekelund, R. B.; Hébert, R. F. (1976): Dupuit and marginal utility: context of the discovery. In History of Political Economy 8 (2), pp. 266-273.

Ekelund, R. B.; Hébert, R. F. (1978): French engineers, welfare economics, and public finance in the nineteenth century. In History of Political Economy 10 (4), pp. 636-668.

Ekelund, R. B.; Hébert, R. F. (1999): Secret origins of modern microeconomics. Dupuit and the engineers. Chicago: University of Chicago Press.

Faccarello, G. (Ed.) (1998): Studies in the history of French political economy. From Bodin to Walras. London, New York: Routledge.

Federal Interagency River Basin Committee (FIARBC) (1950): Proposed practices for economic analysis of river basin projects. Washington, D.C.

Graaff, J. d. V. (1957): Theoretical welfare economics. Cambridge: Univ. Press.

Griffin, R. C. (2012): The origins and ideals of water resource economics in the United States. In Annual Review of Resource Economics 4, pp. 353-377.

Hammond, R. J. (1960): Benefit-cost analysis and water-pollution control. Stanford, Calif.: Food Research Institute, Stanford University.

Hanemann, W. M. (1992): Preface. In Ståle Navrud (Ed.): Pricing the European environment. Oslo, New York: Scandinavian University Press; Oxford University Press, pp. 9-35. 
Hanley, N.; Barbier, E. B. (2009): Pricing nature. Cost-benefit analysis and environmental policy. Cheltenham: Elgar.

Hanley, N.; Spash, C. L. (1993): Cost-benefit analysis and the environment. Aldershot: Elgar.

Henck, S. (2015): Die Entwicklungsgeschichte der Kosten-Nutzen-Analyse als Verwaltungsinstrument. Eine rechtsvergleichende Skizze. In Rechtskultur (4), pp. 1-24.

Hines, L. G. (1973): Precursors to benefit-cost analysis in early United States public investment projects. In Land Economics 49 (3), pp. 310-317.

Hirshleifer, J.; Haven, James C. de; Milliman, J. W. (1960): Water supply. Economics, technology, and policy. Chicago: Univ. of Chicago Pr.

Holmes, B. H. (1972): A history of federal water resources programs, 1800-1960. Washington, D.C.: USDA Econ. Res. Serv.

Hufschmidt, M. M. (2000): Benefit-cost analysis: 1933-1985. In Water Resources Update 116, pp. 42-49.

Interagency Committee on Water Resources (IACWR) (1958): Proposed practices for economic analysis of river basin projects. Rev. (i.e. 2nd) ed. Wash.

Kranakis, E. (1997): Constructing a bridge. An exploration of engineering culture, design, and research in nineteenth-century France and America. Cambridge, Mass.: MIT Press.

Krutilla, J. V.; Eckstein, O. (1958): Multiple purpose river development. Studies in applied economic analysis. Baltimore: Johns Hopkins Press.

Little, I. M. D. (1950): A critique of welfare economics. Oxford: Clarendon Press.

Maass, A.; Hufschmidt, M. M.; Dorfman, R.; Thomas jr., Harold A.; Marglin, S. A.; Fair, G. M. (1962): Design of water-resource systems. New techniques for relating economic objectives, engineering analysis, and governmental planning. London: Macmillan.

McKean, R. N. (1958): Efficiency in government through systems analysis. With emphasis on water resources development. London: John Wiley and Sons Company.

Mohring, H. (1961): Land values and the measurement of highway benefits. In Journal of Political Economy 69 (3), pp. 236-249.

Mosca, M. (1998): Jules Dupuit, the French ingénieurs économistes and the Societé d'économie politique. In Gilbert Faccarello (Ed.): Studies in the history of French political economy. From Bodin to Walras. London, New York: Routledge.

National Resources Board (1934): A report on national planning and public works in relation to natural resources and including land use and water resources with findings and recommendations, Dec 1, 1934. Submitted to the President. June 30 1934. Washington: Govt. Print. Off. 
National Resources Committee (1938): Water planning. Washington D.C.: U.S. Govt. Print. Off.

National Resources Planning Board (1941): Development of resources and stabilization of employment in the United States, January 1941. Washington, D.C.: U.S.G. PO.

Navrud, S. (Ed.) (1992): Pricing the European environment. Oslo, New York: Scandinavian University Press; Oxford University Press.

Pearce, D. (1998): Cost-benefit analysis and environmental policy. In Oxford Review of Economic Policy 14 (4), pp. 84-100.

Pearce, D.; Atkinson, G.; Mourato, S. (2006): Cost-benefit analysis and the environment. Recent developments. Paris: OECD.

Porter, T. M. (1995): Trust in numbers. The pursuit of objectivity in science and public life. Princeton, New Jersy: Princeton University Press.

Rothenberg, J. (1965): Urban renewal programs. In Robert Dorfman (Ed.): Measuring benefits of government investments. Washington, DC: Brookings Inst.

Russell, C. S.; Baumann, D. D. (Eds.) (2009): The evolution of water resource planning and decision making. Institute for Water Resources. Cheltenham: Elgar.

Schumpeter, J. A. (1955): History of economic analysis. Edited from manuscript by Elizabeth Boody Schumpeter. London.

Theocharis, R. D. (1988): C. Courtois: an early contributor to cost-benefit-analysis. In History of Political Economy 20 (2), pp. 265-273.

U.S. Army Corps of Engineers (2008): The U.S. Army Corps of Engineers. A history. 2nd ed. Alexandria, VA: Headquarters, U.S. Army Corps of Engineers, Office of History.

United States (1936): Flood Control Act of 1936. An act authorizing the construction of certain public works on rivers and harbors for flood control, and for other purposes.

Viessman, W., Jr. (2009): A history of the United States water resources planning and development. In Clifford S. Russell, Duane D. Baumann (Eds.): The evolution of water resource planning and decision making. Cheltenham: Elgar, pp. 14-61.

Weisbrod, B. A. (1961): Economics of public health: measuring the economic impact of diseases: University of Pennsylvania Press. 


\section{Paper 2: The historical development of environmental valuation methods and concepts in the context of cost-benefit analysis}

\section{Introduction}

Since the 1960s environmental valuation as a necessary component of cost-benefit analysis has seen a dramatic growth in both application and development after the economists took part in this work. This growth can be attributed to four factors. The first stimulus is the valuation of recreational benefits, simply because recreation has become increasingly popular but is not sold in the market (Banzhaf, 2010). And in 1962 recreation was given official recognition as a primary benefit of federal water projects by Senate Document 97 (The President's Water Resources Council, 1962). Second, public awareness of the environment has expanded with the growth of incomes, wealth, and education as well as increasing reports about environmental degradation (Bennett, 2011). Third, the increased environmental awareness has led to greater political pressure to account for the environment in policy decision-making. In 1970, the National Environmental Policy Act was enacted and the Environmental Protection Agency was created to manage the environmental pollution control (Viessman, 2009). Finally, the advanced professional capacity of economics as a discipline has provided the possibility to meet the demand for environmental valuation.

This paper attempts to illustrate the historical development of environmental valuation methods, beginning with the origin of environmental valuation in section two. Section three deals with the development of travel cost method, while section four considers the parallel development of contingent valuation method. In section five we trace out the evolution of the important concepts in the area of environmental valuation, which influence strongly or rather 
constitute the concept of total economic value in the current context of valuating ecosystem services.

\section{The origin of environmental valuation}

The field of environmental valuation arose initially out of an effort by the National Park Service (NPS) in 1947 to measure the economic value associated with the national parks. At that time there were no entrance fees for visiting the national parks, so no park revenues could be used as a measure of their value. The issue was assigned to a staff economist who wrote to ten distinguished experts soliciting their advice. Almost all of them responded that it would be impossible to measure recreational values in monetary terms. The only dissenter was Harold Hotelling, who argued that the costs of traveling to a park could be seen as a price on visiting the site, which would vary among people coming from different zones. The comparison of this price together with the calculation of visitation rates enables one to construct a good enough approximation of a demand curve, and then to determine the consumers' surplus resulting from the availability of the park (National Park Service, 1949; Hanemann, 2005). However, Hotelling's response received no attention for almost a decade. In 1950 the NPS adopted the so-called twice-cost approach but abandoned it in 1957, when the NPS began using the so-called unit-day value approach based on a previous study of entrance costs at private recreation facilities (Hanemann, 1992; Banzhaf, 2010).

It was just about this time that Hotelling's idea finally resurfaced. The State of California commissioned a study to quantify the recreational benefits associated with the project's reservoirs in the Upper Feather River Basin (State of California, 1957). The results of this study were published in Trice and Wood (1958), which is the first application of what became 
known as the travel cost method. Using data gathered by the California Department of Water Resources and the Fish and Wildlife Service, together with an estimated cost 6.5 cents per mile travelled, Trice and Wood (1958) traced out demand curves for trips to three related sites. Then they measured the benefit of these sites by the difference between the 90th percentile of the demand curves and the median price actually paid. Clearly this measure is not what is known as consumers' surplus. The second application of TCM was performed by Clawson (1959), who was working at Resources for the Future (RFF) which was the third important place, in addition to RAND and the Harvard Water Program, in shaping developments of cost-benefit analysis. Clawson distinguished two different demand curves for a recreation area, one for the total recreation experience and the other for the recreation opportunity per se. The first can be approximately constructed by the actual available data on numbers of visitors from distance zones, total population within the same zones, and average costs for reaching the recreation site from each zone. The second can be derived from the first by simulating the effect of raising entrance fees to the site in a regression equation. Unfortunately, he calculated the benefits of a recreation site by the maximum net revenue which is analogous to monopolist's possible gain, stating that it is hard to capture consumers' surplus in practice and that the usefulness of estimating it is questionable in any situation.

Coincidently in the same year of 1947, Ciriacy-Wantrup (1947) proposed another most practiced approach we have today to survey people by asking them directly their willingnessto-pay in the context of measuring the benefits from soil conservation programs. This approach became known as the contingent valuation method (CVM), because the estimates of economic value are contingent on the features of the scenario posed in the survey. CiriacyWantrup reiterated his call for the use of such direct interview method in his book "Resource 
Conservation: Economics and Policies" (1952). The same with the case of Hotelling, his early suggestion had drawn no attention until the 1960s. In 1958, the NPS engaged Audience Research to find out what the public wanted in relation to the national parks. Audience Research (1958) asked one set of survey respondents about their willingness to pay entrance fees for day trips, which can be deemed the immediate precursor to the use of CVM in the economic evaluation of a project (Hanemann, 1992; Carson, 2011).

\section{The further development of travel cost method}

The early works before 1960 on estimating recreation benefits did not really apply the concept of consumer's surplus. In 1962, Knetsch went to RFF to work with Clawson on the economics of recreation and suggested that consumers' surplus should be taken as the measure of the benefits of a project or an area (Knetsch, 1963). Together, Clawson and Knetsch (1966) published in 1966 the magnum opus "Economics of Outdoor Recreation", which established formally the zonal model of TCM and was among the first studies to estimate consumers' surplus. They followed the two-steps approach developed by Clawson (1959) to derive a demand curve for a recreation site using the mileage distances as an index to costs and adopted the total area under the demand curve suggested by Knetsch (1963) as the measure of total economic benefits provided by the recreation site. More important, they drew attention to a number of practical problems arise from attempting empirical estimates.

The argument over the value of time stems from the economic concept of opportunity cost. The value of time is a complex issue that can further be separated into the value of travel time and on-site time. Failure to account for it may lead to gross error. The zonal TCM requires the aggregation of individual observations into zones so that each zone is represented by a single 
average travel cost or an average value of demographic variables such as sex, age, family composition, income, education and occupation. The averaging process reduces the apparent variability across zones so that statistically non-significant variables are normally ignored in the final demand equations. The zonal TCM also requires that all travel costs are incurred for the single purpose of visiting the site of interest. A difficulty arises when some visitors travel sequentially to more than one site on a trip or travel to the target site for more than one purpose. In addition, it is recognized that a single and isolated recreation site rarely exists and thus there are usually substitutes available, and that the qualities of recreation sites are heterogeneous. The following three decades have thus been shaped by the attempts to refine the travel cost method concerning these difficulties (Ward and Beal, 2000; Hanley et al., 2003). We list the important studies contributed to these subjects during this period in table 1.

Table 1: Contributions to travel cost method in six categories

\begin{tabular}{|c|c|c|}
\hline Category & Study & Contribution \\
\hline \multirow{7}{*}{$\begin{array}{l}\text { Value of travel } \\
\text { time }\end{array}$} & $\begin{array}{l}\text { Becker (1965); } \\
\text { Johnson (1966) }\end{array}$ & $\begin{array}{l}\text { Taking foregone earnings or money wage rate as } \\
\text { time costs }\end{array}$ \\
\hline & $\begin{array}{l}\text { Cesario and } \\
\text { Knetsch (1970) }\end{array}$ & $\begin{array}{l}\text { Using a trade-off function between time and } \\
\text { money costs by considering the value of time to } \\
\text { be equal to some constant rate per hour }\end{array}$ \\
\hline & Cesario (1976) & $\begin{array}{l}\text { Using one-third the average wage rate as the } \\
\text { value of travel time }\end{array}$ \\
\hline & $\begin{array}{l}\text { Cheshire and } \\
\text { Stabler (1976) }\end{array}$ & $\begin{array}{l}\text { Identifying two types of visitors, "pure visitors" } \\
\text { who gained benefit solely from the site and } \\
\text { "meanderers" who derived benefit both from the } \\
\text { journey and the site }\end{array}$ \\
\hline & $\begin{array}{l}\text { McConnell and } \\
\text { Strand (1981) }\end{array}$ & $\begin{array}{l}\text { Arguing that the cost would be some proportion } \\
\text { of the individual's market wage rate and that this } \\
\text { proportion could be determined from sample data } \\
\text { and could thus vary from one study to another }\end{array}$ \\
\hline & Smith et al. (1983) & $\begin{array}{l}\text { Proposing a projected wage rate to appraise an } \\
\text { individual's opportunity cost of travel time based } \\
\text { on the individual's personal and residential site } \\
\text { characteristics }\end{array}$ \\
\hline & $\begin{array}{l}\text { Bockstael et al. } \\
\text { (1987) }\end{array}$ & $\begin{array}{l}\text { Distinguishing individuals with fixed work hours } \\
\text { from individuals with discretionary work } \\
\text { schedules, for the former they faced two } \\
\text { constraints of income and time, leading to a }\end{array}$ \\
\hline
\end{tabular}




\begin{tabular}{|c|c|c|}
\hline & & $\begin{array}{l}\text { demand function with travel costs and travel time } \\
\text { as independent variables, for the latter time is } \\
\text { reflected by the wage rate and combined with } \\
\text { travel costs to produce one full cost variable }\end{array}$ \\
\hline & Walsh et al. (1990) & $\begin{array}{l}\text { Reporting that auto driving could be the primary } \\
\text { purpose for pleasure or sightseeing on a scenic } \\
\text { route, estimating a statistical demand function for } \\
\text { the recreation function of pleasure driving, and } \\
\text { showing that the consumptive value of travel time } \\
\text { is related to several variables influenced by the } \\
\text { quality of driving experience. }\end{array}$ \\
\hline & Shaw (1992) & $\begin{array}{l}\text { Suggesting that the opportunity cost of time could } \\
\text { take some fraction of the wage rate as a lower } \\
\text { bound and an upper bound of two or three times } \\
\text { the wage rate }\end{array}$ \\
\hline & Casey et al. (1995) & $\begin{array}{l}\text { Applying a contingent valuation type question } \\
\text { included within the travel cost framework to elicit } \\
\text { the opportunity cost of time }\end{array}$ \\
\hline & $\begin{array}{l}\text { McKean et al. } \\
(1995)\end{array}$ & $\begin{array}{l}\text { Concluding that increased survey information is } \\
\text { necessary to apply an appropriate model to each } \\
\text { individual by testing a pooled model }\end{array}$ \\
\hline & Wilman (1980) & $\begin{array}{l}\text { Arguing that on-site time costs could be omitted } \\
\text { under some circumstances but should not be } \\
\text { valued at the same rate as travel time if it is } \\
\text { included }\end{array}$ \\
\hline & Smith et al. (1983) & $\begin{array}{l}\text { Considering on-site time as part of the cost of } \\
\text { visiting a site }\end{array}$ \\
\hline & Ward (1984) & $\begin{array}{l}\text { Proposing that discretionary trip-related time } \\
\text { spent on-site is an endogenous demand } \\
\text { determinant }\end{array}$ \\
\hline $\begin{array}{l}\text { Value of on- } \\
\text { site time }\end{array}$ & $\begin{array}{l}\text { Kealy and Bishop } \\
\text { (1986) }\end{array}$ & $\begin{array}{l}\text { Hypothesizing that individuals choose the total } \\
\text { number of recreation days and take these in their } \\
\text { trip plan most suited to them by assuming on-site } \\
\text { time is exogenous but needs not be constant } \\
\text { across recreationists }\end{array}$ \\
\hline & Wilman (1987) & $\begin{array}{l}\text { Deriving a constant length expected visit demand } \\
\text { curve by excluding the cost of on-site time }\end{array}$ \\
\hline & McConnell (1992) & $\begin{array}{l}\text { Discussing the dual role of on-site time - not only } \\
\text { a determinant of the utility and but a source of } \\
\text { cost of the trip, and showing that the standard } \\
\text { travel cost demand function would take a } \\
\text { particularly simple form when on-site time were } \\
\text { endogenously chosen }\end{array}$ \\
\hline & Larson (1993) & $\begin{array}{l}\text { Concluding that on-site time is chosen } \\
\text { simultaneously with trip length by assuming that } \\
\text { individuals choose both the number of trips and } \\
\text { total time at site }\end{array}$ \\
\hline
\end{tabular}




\begin{tabular}{|c|c|c|}
\hline \multirow[b]{2}{*}{$\begin{array}{l}\text { Demographic } \\
\text { characteristics }\end{array}$} & $\begin{array}{l}\text { Brown and Nawas } \\
\text { (1973); Gum and } \\
\text { Martin (1975) }\end{array}$ & $\begin{array}{l}\text { Introducing the idea of using observations on } \\
\text { individual recreationists rather than averaging } \\
\text { individual observations within distance zones, } \\
\text { known as individual TCM }\end{array}$ \\
\hline & Brown et al. (1983) & $\begin{array}{l}\text { Proposing a combination of zonal TCM and } \\
\text { individual TCM where the number of trips by } \\
\text { each individual in a sample is scaled up to } \\
\text { represent the zonal total use and then divided by } \\
\text { the zonal population adjusted to individual shares }\end{array}$ \\
\hline \multirow{4}{*}{$\begin{array}{l}\text { Multi-site or } \\
\text { multi-purpose } \\
\text { trips }\end{array}$} & $\begin{array}{l}\text { Haspel and } \\
\text { Johnson (1982) }\end{array}$ & $\begin{array}{l}\text { Assigning fractions of total travel costs to each } \\
\text { site and then estimating separate site demand } \\
\text { curves based on itinerary data }\end{array}$ \\
\hline & $\begin{array}{l}\text { Clough and Meister } \\
\text { (1991) }\end{array}$ & $\begin{array}{l}\text { Adjusting directly the consumer surplus estimate } \\
\text { by using a trip index which relates the site visit to } \\
\text { the total time on a trip rather than adjusting the } \\
\text { travel cost variable }\end{array}$ \\
\hline & $\begin{array}{l}\text { Mendelsohn et al. } \\
\text { (1992) }\end{array}$ & $\begin{array}{l}\text { Proposing a solution of combining a set of } \\
\text { recreation sites as a single joint site }\end{array}$ \\
\hline & $\begin{array}{l}\text { Parsons and Wilson } \\
\text { (1997) }\end{array}$ & $\begin{array}{l}\text { Incorporating incidental consumption into a single } \\
\text { site demand model by treating incidental } \\
\text { consumption as a complementary good }\end{array}$ \\
\hline \multirow{6}{*}{$\begin{array}{l}\text { Effect of } \\
\text { substitutes }\end{array}$} & $\begin{array}{l}\text { Burt and Brewer } \\
\text { (1971); Cicchetti et } \\
\text { al. (1976) }\end{array}$ & $\begin{array}{l}\text { Valuating a new site introduced in a situation } \\
\text { where substitute sites already exist by deriving a } \\
\text { system of demand functions for the set of } \\
\text { alternative recreation sites and then determining } \\
\text { the single price change that the new site induce } \\
\text { for the closest substitute }\end{array}$ \\
\hline & $\begin{array}{l}\text { Hof and King } \\
(1982)\end{array}$ & $\begin{array}{l}\text { Discussing the possibility of capturing substitute } \\
\text { effects with a single demand function }\end{array}$ \\
\hline & $\begin{array}{l}\text { Caulkins et al. } \\
\text { (1985) }\end{array}$ & $\begin{array}{l}\text { Pointing out that the omission of the substitute } \\
\text { prices may not necessarily lead to an overestimate } \\
\text { of the site's value and that the sign of the } \\
\text { omission bias depended on the relationship } \\
\text { between the sites and the correlation between } \\
\text { their corresponding travel costs }\end{array}$ \\
\hline & Rosenthal (1987) & $\begin{array}{l}\text { Finding that the omission of substitute prices } \\
\text { from the TCM leads to higher overestimate of } \\
\text { individual consumer surplus and the degree of } \\
\text { overestimate depends on the spatial distribution } \\
\text { and characteristics of the substitute sites }\end{array}$ \\
\hline & Kling (1989) & $\begin{array}{l}\text { Showing that there is no bias to the welfare } \\
\text { estimate of a single site price change if the } \\
\text { omitted substitute price is uncorrelated with the } \\
\text { included own price }\end{array}$ \\
\hline & Freeman (1993) & $\begin{array}{l}\text { Suggesting researchers ask visitors what other site } \\
\text { they visit most frequently and include only that } \\
\text { site's price as the relevant substitute price }\end{array}$ \\
\hline
\end{tabular}




\begin{tabular}{|c|c|c|}
\hline \multirow{7}{*}{ Site qualities } & Wetzel (1977) & $\begin{array}{l}\text { Regarding congestion is an attribute of site quality } \\
\text { and concluding that failure to account for } \\
\text { congestion in TCM would always underestimate } \\
\text { recreation benefits at a site }\end{array}$ \\
\hline & Freeman (1979) & $\begin{array}{l}\text { Incorporating water quality effects on recreation } \\
\text { demand and benefits into the conventional TCM }\end{array}$ \\
\hline & McConnell (1980) & $\begin{array}{l}\text { Arguing that recreation benefits should be } \\
\text { measured with congestion held constant }\end{array}$ \\
\hline & Smith (1981) & $\begin{array}{l}\text { Suggesting that individual anticipation of } \\
\text { congestion should be reflected in TCM }\end{array}$ \\
\hline & $\begin{array}{l}\text { Vaughan and } \\
\text { Russell (1982); } \\
\text { Smith et al. (1983) }\end{array}$ & $\begin{array}{l}\text { Proposing the varying parameter travel cost } \\
\text { model which assumes visitation to a site is a } \\
\text { function of site characteristics from a pooled } \\
\text { sample of all available observations }\end{array}$ \\
\hline & $\begin{array}{l}\text { Brown and } \\
\text { Mendelsohn (1984) }\end{array}$ & $\begin{array}{l}\text { Providing the hedonic travel cost model which } \\
\text { treats heterogeneous sites as a bundle of } \\
\text { characteristics and decomposes the site price into } \\
\text { a set of implicit prices for each characteristic }\end{array}$ \\
\hline & $\begin{array}{l}\text { Ribaudo and Epp } \\
\text { (1984) }\end{array}$ & $\begin{array}{l}\text { Using sample discrimination to construct an } \\
\text { individual travel cost demand function for the site } \\
\text { in its current condition by surveying those } \\
\text { entering a given recreation site and a demand } \\
\text { function for the site contingent on the higher } \\
\text { quality through a hypothetical description of the } \\
\text { site in a better condition in the survey }\end{array}$ \\
\hline
\end{tabular}

Currently, random utility model (RUM) in the framework of discrete choice methods has become the dominant approach for valuing recreation. If the traditional TCM can be said to focus on the question of "how many trips to a particular site", the purpose of RUM is instead to answer the question of "where to visit on a particular trip". The traditional TCM is based on a conventional demand function, while the basis of RUMs is a preference function. The idea of RUM was originally introduced by McFadden (1974) and first applied to recreation by Hanemann (1978). Since then RUM has exhibited the powerful capability to deal with the most difficulties discussed above and the perfect appropriateness with Hicksian welfare measures. To describe the extensive development of RUM is beyond the scope of this paper. The limitation of RUM for estimating seasonal benefits motivated research on Kuhn-Tucker model (KTM) which allows for incorporating the frequency of visits to each of the defined 
alternatives (Phaneuf and Smith, 2005; Adamowicz et al., 2011). Both of RUM and KTM represent the state of the art in recreation valuation.

\section{The further development of contingent valuation method}

Along with the substantial evolution of travel cost method, contingent valuation method has also progressed rapidly during the same period. The first formal CVM study was conducted by Davis in his 1963 Harvard dissertation about the value of outdoor recreation. He established the comprehensive technique of $\mathrm{CVM}$ in terms of its treatment of theoretical economic issues, sampling issues, survey design, and statistical analysis and interpretation of the data collected. Later, Davis worked with Knetsch for comparing a CVM estimate to a corresponding estimate resulted from TCM and found that the two methods produced similar estimates (Knetsch and Davis, 1966). This was the first study to compare the results from the two dominant valuation methods.

Influenced by Davis, Ridker (1967) included some open-ended questions to ask people's willingness-to-pay (WTP) for air pollution control in Philadelphia and Syracuse, Brown and Hammack (1972) used brief questionnaire to survey hunters in seven western states to elicit their maximum WTP for the right to hunt waterfowl and their minimum willingness-to-accept (WTA) to give up this right, Cicchetti and Smith (1973) asked the actual users of the Spanish Peaks Primitive Area in Montana about their WTP for reducing congestion in this area from other users, and Darling (1973) used personal interviews to ask the WTP for three urban water parks in California. The study of Randall et al. (1974), which built directly on the bidding games technique suggested by Davis, played an important role in the early development of CVM. Their effort was remarkable for the theoretical rigor, the measure of aesthetic 
environmental improvements which could not be valued by alternative methods, the use of photographs to depict visibility levels of environmental damage, and the creative design of different bidding games formats based on appropriate payment vehicles.

Most studies during the period from the late 1970s through the late 1980s were exploratory. Practically CVM has been applied to value a wide variety of goods, including recreation (McConnell, 1977), hunting (Cocheba and Langford, 1978), skiing (Walsh et al., 1983), improvements in water quality (Greenley et al., 1981) and air quality (Brookshire et al., 1976). Another focus lied in the refinement of the methodology by identifying and testing for the potential biases that arose in the empirical applications (Randall et al., 1978; Schulze et al., 1981). Parallel theoretical work recognized that CVM data are generated in forms consistent with the theory of welfare change measurement (Freeman, 1979; Just et al., 1982).

In 1984 Hanemann developed a unified framework for formulating discrete and continuous consumer choices, which implied that both CVM and TCM shared the same underlying random utility theory. Based on this finding, an important innovation in the early 1990s was to combine stated and revealed preference data for the valuation of nonmarket goods. The idea originated in the transportation research by Ben-Akiva and Morikawa (1990). But the first application in environmental economics was made by Cameron (1992) to combine contingent valuation method and travel cost method in a recreational fishing study.

In contrary to travel cost method, the landmark work in the history of contingent valuation method emerged until 1989 when Mitchell and Carson published their book "Using Surveys to Value Public Goods: The Contingent Valuation Method". This book established a solid coherent theoretical and methodological framework - welfare economics and survey research 
- for this method, and replied effectively to the skeptics whether respondents in surveys could answer honestly and meaningfully. It also offered a systematic comprehensive typology of the different types of biases and misspecifications for understanding and obtaining reliable and valid estimates, and showed how most of these could be minimized or avoided by careful survey design. Since the publication of this book CVM has no longer been an experimental methodology and the number of CVM studies has rapidly increased. We list the long-running debates in the history of CVM in Table 2, including the divergence between WTP and WTA, the reason of this divergence, and the choice of the elicitation format in a survey.

Table 2: The debates in the history of CVM

\begin{tabular}{|c|c|c|}
\hline Debate & Study & Argument \\
\hline \multirow{5}{*}{$\begin{array}{l}\text { The } \\
\text { divergence } \\
\text { between WTP } \\
\text { and WTA }\end{array}$} & $\begin{array}{l}\text { Hammack and } \\
\text { Brown (1974) }\end{array}$ & $\begin{array}{l}\text { Respondents' WTA were about four times larger than } \\
\text { the same respondents' WTP for the same good. }\end{array}$ \\
\hline & Willig (1976) & $\begin{array}{l}\text { WTP and WTA should be fairly close for price change } \\
\text { and the Marshallian consumer's surplus lay between } \\
\text { them. }\end{array}$ \\
\hline & $\begin{array}{l}\text { Randall and Stoll } \\
\text { (1980) }\end{array}$ & $\begin{array}{l}\text { Bounds on the difference between WTP and WTA can } \\
\text { be rigorously calculated and this difference should not } \\
\text { be great. }\end{array}$ \\
\hline & $\begin{array}{l}\text { Knetsch and } \\
\text { Sinden (1984); } \\
\text { Gregory (1986); } \\
\text { Coursey et al. } \\
(1987)\end{array}$ & WTA is usually considerably higher than WTP. \\
\hline & Knetsch (1990) & $\begin{array}{l}\text { Implications of this disparity can be linked to the } \\
\text { economic analysis of environmental problems and the } \\
\text { design of environmental policies. }\end{array}$ \\
\hline \multirow{4}{*}{$\begin{array}{l}\text { The reason of } \\
\text { this } \\
\text { divergence }\end{array}$} & $\begin{array}{l}\text { Kahneman and } \\
\text { Tversky (1979) }\end{array}$ & $\begin{array}{l}\text { The value function is steeper for losses than for gains } \\
\text { based on prospect theory. }\end{array}$ \\
\hline & Bishop et al. (1983) & $\begin{array}{l}\text { People tend to reject the property rights implied by } \\
\text { WTA question. }\end{array}$ \\
\hline & $\begin{array}{l}\text { Hoehn and Randall } \\
\text { (1987) }\end{array}$ & People are cautious in contingent valuation surveys. \\
\hline & Hanemann (1991) & $\begin{array}{l}\text { There is no presumption that WTP and WTA must be } \\
\text { close in value for quantity change because the } \\
\text { difference between WTP and WTA depends on an } \\
\text { income effect as well as a substitution effect. Holding } \\
\text { income effect constant, the smaller is the substitution } \\
\text { effect, i.e. for nonmarket goods, the greater the } \\
\text { disparity between WTP and WTA. }\end{array}$ \\
\hline
\end{tabular}




\begin{tabular}{|c|c|c|}
\hline & $\begin{array}{l}\text { Horowitz and } \\
\text { McConnell (2002) }\end{array}$ & $\begin{array}{l}\text { The WTA/WTP ratio is higher for nonmarket goods, } \\
\text { and the divergence exists robustly in various } \\
\text { experimental markets and widespread in actual } \\
\text { markets, regardless of whether stated preference or } \\
\text { revealed preference data are used. }\end{array}$ \\
\hline \multirow{7}{*}{$\begin{array}{l}\text { The choice of } \\
\text { the elicitation } \\
\text { format in a } \\
\text { survey }\end{array}$} & Davis (1963) & The bidding game. \\
\hline & $\begin{array}{l}\text { Cicchetti and Smith } \\
\text { (1973) }\end{array}$ & The open-ended direct question. \\
\hline & $\begin{array}{l}\text { Bishop and } \\
\text { Heberlein (1979) }\end{array}$ & $\begin{array}{l}\text { The single binary choice format, which simplifies the } \\
\text { task of respondents by asking respondents to make a } \\
\text { judgement about only one given price but therefore } \\
\text { requires a larger sample to attain a given level of } \\
\text { precision. }\end{array}$ \\
\hline & $\begin{array}{l}\text { Mitchell and } \\
\text { Carson (1981) }\end{array}$ & $\begin{array}{l}\text { To overcome the shortcomings of the bidding game } \\
\text { and the open-ended direct question, the payment card } \\
\text { format was proposed by asking respondents to pick } \\
\text { one of an array of numbers or any number in between } \\
\text { as their WTP. }\end{array}$ \\
\hline & $\begin{array}{l}\text { Carson (1985); } \\
\text { Hanemann (1985) }\end{array}$ & $\begin{array}{l}\text { To increase the statistical efficiency of the single } \\
\text { binary choice format, the double-bounded } \\
\text { dichotomous choice format was proposed by adding a } \\
\text { second round response with a yes or no answer. }\end{array}$ \\
\hline & $\begin{array}{l}\text { Kealy and Turner } \\
\text { (1993) }\end{array}$ & $\begin{array}{l}\text { Different formats often yielded significantly dissimilar } \\
\text { estimation results for public good. }\end{array}$ \\
\hline & Boyle et al. (1996) & $\begin{array}{l}\text { Discrete format like single binary choice produced } \\
\text { higher WTP estimates than did continuous format like } \\
\text { open-ended response. }\end{array}$ \\
\hline
\end{tabular}

Recently, the elicitation format has been extended to build a method family known as choice modelling, which includes contingent rating (Westbrook, 1980; Roe et al., 1996), contingent ranking (Beggs et al., 1981; Garrod and Willis, 1997), paired comparison (Huber and McCann, 1982; Loomis et al., 1998), and choice experiment (Louviere and Woodworth, 1983; Carson et al., 1990). These methods share three common points. First, they originated in the marketing research in the 1980s with a general name of conjoint analysis and have recently been applied to environmental valuation in the 1990s as an alternative to CVM. Second, they are based on the idea that a product can be treated as a bundle of attributes or characteristics and the levels they take. Third, in comparison to CVM, the major difference of 
choice modelling is that a series of options are evaluated by respondents rather than only one or two. Currently, the choice experiment method (CEM) has become increasingly popular in the environmental valuation applications, because only this method within the choice modelling family is soundly consistent with the random utility theory as well as the theory of welfare economics (Morrison et al., 1996; Bateman et al., 2002). Adamowicz et al. (1994) presented the first application of joint estimation with choice experiment method and random utility model.

\section{The concept of total economic value}

Along with the dramatic evolution of environmental valuation methods, new concepts of value were introduced to serve as the foundations of these methods and have expanded greatly the possible applications of cost-benefit analysis. The first contribution was made by Weisbrod (1964), who raised the concept of option value. Option value was recognized as the amount some people will be willing to pay for the option of visiting a national park in the future and thus should be regarded as an additional form of benefit that must be accounted for in cost-benefit analysis. Long (1967) objected this concept by arguing that Weisbrod's option value was nothing more than the expected consumers' surplus. Lindsay (1969) presented a rebuttal emphasizing uncertainty as the source of option value. Byerlee (1971) agreed with Long and suggested generalizing the definition of consumers' surplus to include explicitly uncertainty. Following Lindsay's insights, Cicchetti and Freeman (1971) rested option value on the concept of risk aversion premium which is consistent with consumer theory and showed that omission of the option value would result in a significant underestimate of benefits. Their conclusion was unfortunately based on an unacceptable method of comparing utilities. Correcting this fundamental flaw, Schmalensee (1972) proved that option value 
could be positive, negative or zero for a risk-averse individual under plausible conditions and therefore suggested assuming option value to be zero in empirical studies.

It is worth mentioning here the concept of quasi-option value which was introduced and developed by Arrow and Fisher (1974) and Henry (1974). They were concerned primarily with the effect of irreversibility on decisions about preservation versus development of a natural environment and used this term to indicate the value of information secured by delaying a decision to commit to some irreversible action. However, as Bishop (1982) and Pearce et al. (2006) pointed out, their concept has little common with the concept of option value discussed above.

From the experience in applying cost-benefit analysis to water resource projects, Krutilla (1967) introduced the concept of non-use value, more specific, existence value, as another significant value component of environmental resources by recognizing that some people place a value on the mere existence of biological and geomorphological variety and its widespread distribution. Krutilla and Fisher (1975) offered a bequest motive as possible explanation for this pure existence value. Randall and Stoll (1983) summarized, followed by Bishop et al. (1987), that altruism is the primary motivation for non-use value. Such altruism could be towards future generations (bequest value), might extend to other users (altruist value), and could also be focused upon nature itself (existence value). Employing an empirical model to analyse motives, Madariaga and McConnell (1987) found that the motives underlying existence value matter the role of existence value in cost-benefit analysis. Non-use values can be deemed the echo of intangibles at the very beginning of cost-benefit analysis in 
the 1930s, and there is already the consensus among economists that they can only be measured by the contingent valuation method.

Furthermore, in considering the value of a wildlife species, Boyle and Bishop (1987) identified three categories of use values. The first category is consumptive use value which arises from the consumptive use of a wildlife resource, e.g. hunting and fishing. The second is non-consumptive use value which arises when people come in contact with wildlife in its natural habitat but do not take them from the wild, e.g. wildlife viewing and bird watching. Consumptive and non-consumptive use values together are referred to as direct use value. In contrast, the third category is referred to as indirect use value which includes reading about wildlife, viewing pictures of wildlife and watching television programs about wildlife.

Randall and Stoll (1983) mentioned a concept of total value that consisted of use value and existence value. Later, Randall (1987) modified this concept to total economic value (TEV). Strangely, he published his paper "total economic value as a basis for policy" in a noneconomic journal, which leads to few acknowledgement and quotation among economists and cost-benefit analysts. In his initial view, total economic value consisted of use value (past and current use values and expected value of future use), option value, quasi-option value as well as existence value. It was not until 1990s that the framework of TEV obtained its current form (Pearce, 1993; Figure 1). 


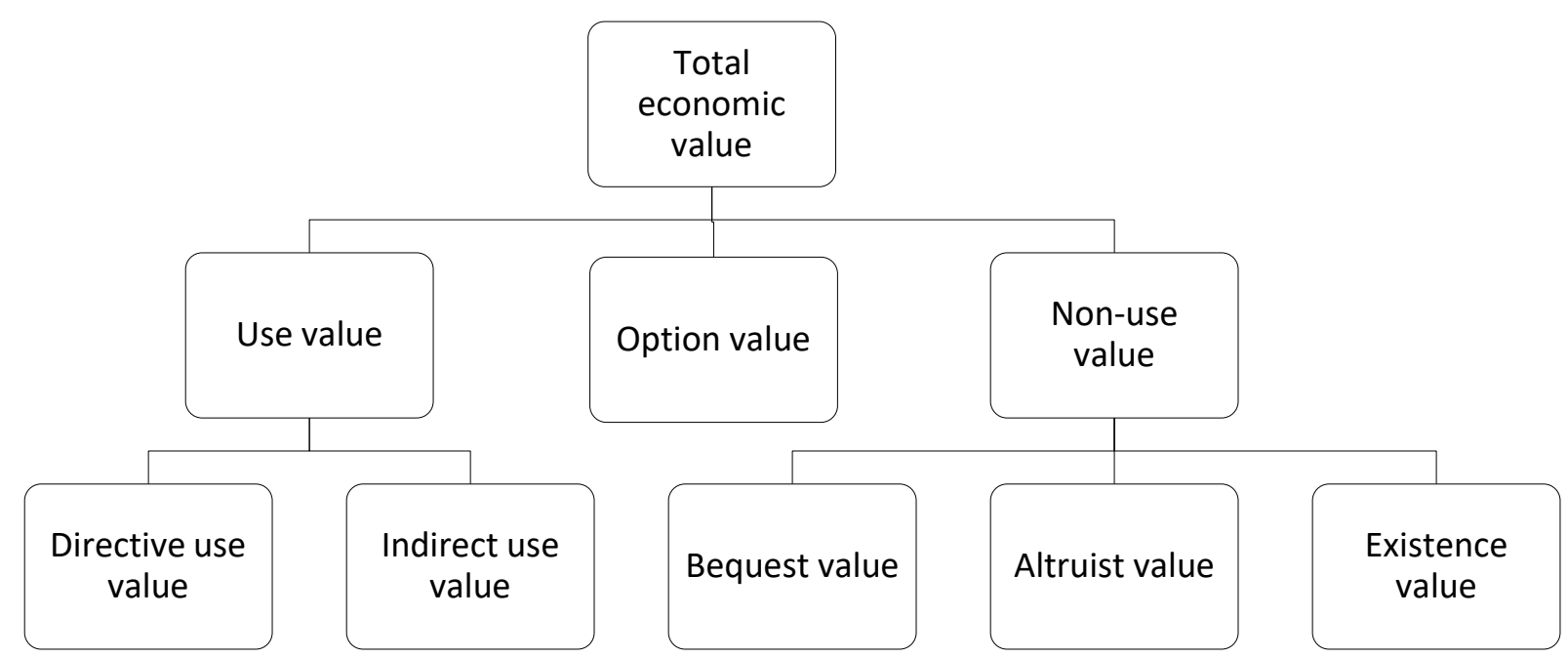

Figure 1: The framework of total economic value

\section{Conclusion}

Environmental valuation methods, as supplements of cost-based valuation methods developed in the history of cost-benefit analysis, were put forward to meet the demand for valuating recreational benefits. This paper showed the historical development of the most important methods, TCM and CVM, which were proposed accidentally in the same year, of the revealed preference and stated preference approaches, and discussed the difficulties and debates in their histories. The current development of RUM and CEM, the successors of TCM and CVM respectively, were also mentioned. The combined approaches and the comparison of the both approaches are the comprehensible results in a logical way. In addition, we are the first to trace out the history of the concept of total economic value, although this concept has been widely used as a framework for evaluating our environment or ecosystem services. The concepts of option value and non-use value were raised in the context of environmental valuation. The further refinement and classification of economic values represents not only the practical need of cost-benefit analysis but also the advanced understanding of our environment. 


\section{References}

Adamowicz, W.; Louviere, J.; Williams, M. (1994): Combining revealed and stated preference methods for valuing environmental amenities. In Journal of Environmental Economics and Management 26 (3), pp. 271-292.

Adamowicz, W. L.; Naidoo, R.; Nelson, E.; Polasky, S.; Zhang, J. (2011): Nature-based tourism and recreation. In Peter Kareiva, Heather Tallis, Taylor H. Ricketts, Gretchen C. Daily, Stephen Polasky (Eds.): Natural capital. Theory and practice of mapping ecosystem services. Oxford [England], New York: Oxford University Press (Oxford biology).

Arrow, K. J.; Fisher, A. C. (1974): Environmental preservation, uncertainty, and irreversibility. In Quarterly Journal of Economics 88 (2), pp. 312-319.

Audience Research (1958): A study of outdoor recreational activities and preferences of the population living in the region of the Delaware River Basin. Princeton, N.J.: Audience Research, Inc.

Banzhaf, H. S. (2010): Consumer surplus with apology: a historical perspective on nonmarket valuation and recreation demand. In Annual review of Resource Economics.

Bateman, I. J.; Carson, R. T.; Day, B.; Hanemann, W. M.; Hanley, N.; Hett, T. et al. (2002): Economic valuation with stated preference techniques. A manual: Edward Elgar.

Becker, G. S. (1965): A theory of the allocation of time. In Economic Journal 75 (299), pp. 493-517.

Beggs, S.; Cardell, S.; Hausman, J. (1981): Assessing the potential demand for electric cars. In Journal of econometrics 17 (1), pp. 1-19.

Ben-Akiva, M.; Morikawa, T. (1990): Estimation of switching models from revealed preferences and stated intentions. In Transportation Research Part A: General 24 (6), pp. 485-495.

Bennett, J. (Ed.) (2011): The international handbook on non-market environmental valuation. Cheltenham, U.K., Northampton, Mass.: Edward Elgar.

Bennett, J. (2011): The rise and rise of non-market environmental valuation. In Jeff Bennett (Ed.): The international handbook on non-market environmental valuation. Cheltenham, U.K., Northampton, Mass.: Edward Elgar, pp. 1-13.

Bishop, R. C.; Boyle, K. J.; Welsh, M. P. (1987): Toward total economic valuation of Great Lakes fishery resources. In Transactions of the American Fisheries Society 116 (3), pp. 339345.

Bishop, R. C.; Heberlein, T. A. (1979): Measuring values of extra-market goods - are indirect measures biased. In American Journal of Agricultural Economics 61 (5), pp. 926-930. 
Bishop, R. C.; Heberlein, T. A.; Kealy, M. J. (1983): Hypothetical bias in contingent valuation: results from a simulated market. In Natural Resources Journal 23 (3), pp. 619-633.

Bishop, R. C. (1982): Option value: an exposition and extension. In Land Economics 58 (1), pp. 1-15.

Bockstael, N. E.; Strand, I. E.; Hanemann, W. M. (1987): Time and the recreational demand model. In American Journal of Agricultural Economics 69 (2), pp. 293-302.

Boyle, K. J.; Bishop, R. C. (1987): Valuing wildlife in benefit-cost analyses - a case-study involving endangered species. In Water Resources Research 23 (5), pp. 943-950.

Boyle, K. J.; Johnson, F. R.; McCollum, D. W.; Desvousges, W. H.; Dunford, R. W.; Hudson, S. P. (1996): Valuing public goods: Discrete versus continuous contingent valuation responses. In Land Economics 72 (3), pp. 381-396.

Brookshire, D. S.; Ives, B. C.; Schulze, W. D. (1976): The valuation of aesthetic preferences. In Journal of Environmental Economics and Management 3 (4), pp. 325-346.

Brown, W. G.; Sorhus, C.; Chouyang, B.; Richards, J. A. (1983): Using individual observations to estimate recreation demand-functions - a caution. In American Journal of Agricultural Economics 65 (1), pp. 154-157.

Brown, W. G.; Nawas, F. (1973): Impact of aggregation on the estimation of outdoor recreation demand functions. In American Journal of Agricultural Economics 55 (2), pp. 246249.

Brown Jr, G.; Mendelsohn, R. (1984): The hedonic travel cost method. In The Review of Economics and Statistics, pp. 427-433.

Brown Jr, G. M.; Hammack, J. (1972): A preliminary investigation of the economics of migratory waterfowl. In Natural Environments: Studies in Theoretical and Applied Analysis, p. 171.

Burt, O. R.; Brewer, D. (1971): Estimation of net social benefits from outdoor recreation. In Econometrica 39 (5).

Byerlee, D. R. (1971): Option demand and consumer surplus - comment. In Quarterly Journal of Economics 85 (3), pp. 523-527.

Cameron, T. A. (1992): Combining contingent valuation and travel cost data for the valuation of nonmarket goods. In Land Economics 68 (3), pp. 302-317.

Carson, R.; Hanemann, M.; Steinberg, D. (1990): A discrete choice contingent valuation estimate of the value of Kenai king salmon. In Journal of Behavioral Economics 19 (1), pp. 53-68.

Carson, R. T. (2011): Contingent valuation. A comprehensive bibliography and history. Cheltenham, UK: Edward Elgar. 
Carson, R. T. (1985): Three essays on contingent valuation.

Casey, J. F.; Vukina, T.; Danielson, L. E. (1995): The economic value of hiking: further considerations of opportunity cost of time in recreational demand models. In Journal of Agricultural and Applied Economics 27 (2), pp. 658-668.

Caulkins, P. P.; Bishop, R. C.; Bouwes, N. W. (1985): Omitted cross-price variable biases in the linear travel cost model - correcting common misperceptions. In Land Economics 61 (2), pp. 182-187.

Cesario, F. J. (1976): Value of time in recreation benefit studies. In Land Economics 52 (1), pp. 32-41.

Cesario, F. J.; Knetsch, J. L. (1970): Time bias in recreation benefit estimates. In Water Resources Research 6 (3), pp. 700-704.

Cheshire, P. C.; Stabler, M. J. (1976): Joint consumption benefits in recreational site surplus empirical estimate. In Regional Studies 10 (3), pp. 343-351.

Cicchetti, C. J.; Fisher, A. C.; Smith, V. K. (1976): An econometric evaluation of a generalized consumer surplus measure: the mineral king controversy. In Econometrica, pp. 1259-1276.

Cicchetti, C. J.; Freeman III, A. M. (1971): Option demand and consumer surplus: further comment. In The Quarterly Journal of Economics, pp. 528-539.

Cicchetti, C. J.; Smith, V. K. (1973): Congestion, quality deterioration, and optimal use: Wilderness recreation in the Spanish peaks primitive area. In Social Science Research 2 (1), pp. 15-30.

Ciriacy-Wantrup, S. V. (1947): Capital returns from soil conservation practices. In Journal of Farm Economics 29 (4), pp. 1181-1202.

Ciriacy-Wantrup, S. V. (1952): Resource conservation: economics and policies. Berkeley: University of California Press.

Clawson, M. (1959): Methods of measuring the demand for and value of outdoor recreation. Washington, D.C.: Resources for the Future, Inc.

Clawson, M.; Knetsch, J. L. (1966): Economics of outdoor recreation. Baltimore: Published for Resources for the Future by Johns Hopkins Press.

Clough, P. W.; Meister, A. D. (1991): Allowing for multiple-site visitors in travel cost analysis. In Journal of Environmental Management 32 (2), pp. 115-125.

Cocheba, D. J.; Langford, W. A. (1978): Wildlife valuation: the collective good aspect of hunting. In Land Economics, pp. 490-504. 
Coursey, D. L.; Hovis, J. L.; Schulze, W. D. (1987): The disparity between willingness to accept and willingness to pay measures of value. In Quarterly Journal of Economics 102 (3), pp. 679-690.

Darling, A. H. (1973): Measuring benefits generated by urban water parks. In Land Economics 49 (1), pp. 22-34.

Davis, R. K. (1963): The value of outdoor recreation. An economic study of the Maine woods.

Freeman, A. M. (1979): The benefits of environmental improvement. Theory and practice. Baltimore, Md.: Hopkins Univ. Press.

Freeman, A. M. (1993): The measurement of environmental and resource values. Theory and methods. Washington, DC: Resources for the Future.

Garrod, G. D.; Willis, K. G. (1997): The non-use benefits of enhancing forest biodiversity: a contingent ranking study. In Ecological Economics 21 (1), pp. 45-61.

Greenley, D. A.; Walsh, R. G.; Young, R. A. (1981): Option value: empirical evidence from a case study of recreation and water quality. In The Quarterly Journal of Economics, pp. 657673.

Gregory, R. (1986): Interpreting measures of economic loss - evidence from contingent valuation and experimental studies. In Journal of Environmental Economics and Management 13 (4), pp. 325-337.

Gum, R. L.; Martin, W. E. (1975): Problems and solutions in estimating the demand for and value of rural outdoor recreation. In American Journal of Agricultural Economics 57 (4), pp. 558-566.

Hammack, J.; Brown, G. M. (1974): Waterfowl and wetlands: toward bioeconomic analysis. Washington D.C.: Resources for the Future; distributed by the Johns Hopkins University Press, Baltimore.

Hanemann, W. M. (1984): Discrete continuous models of consumer demand. In Econometrica 52 (3), pp. 541-561.

Hanemann, W. M. (1978): A methodological and empirical study of the recreation benefits from water quality improvement. Berkeley, Calif.: Dept. of Agricultural and Resource Economics, University of California.

Hanemann, W. M. (1985): Some issues in continuous and discrete response contingent valuation studies. In Northeastern Journal of Agricultural Economics 14 (1), pp. 5-13.

Hanemann, W. M. (1991): Willingness to pay and willingness to accept - how much can they differ. In American Economic Review 81 (3), pp. 635-647. 
Hanemann, W. M. (1992): Preface. In Ståle Navrud (Ed.): Pricing the European environment. Oslo, New York: Scandinavian University Press; Oxford University Press, pp. 9-35.

Hanemann, W. M. (2005): The economic conception of water. University of California, Berkeley.

Hanley, N.; Shaw, W. D.; Wright, R. E. (2003): Introduction. In Nick Hanley, W. Douglass Shaw, Robert E. Wright (Eds.): The new economics of outdoor recreation. Cheltenham, Glos., UK, Northhampton, Mass.: E. Elgar.

Hanley, N.; Shaw, W. D.; Wright, R. E. (Eds.) (2003): The new economics of outdoor recreation. Cheltenham, Glos., UK, Northhampton, Mass.: E. Elgar.

Haspel, A. E.; Johnson, F. R. (1982): Multiple destination trip bias in recreation benefit estimation. In Land Economics 58 (3), pp. 364-372.

Henry, C. (1974): Option values in the economics of irreplaceable assets. In The Review of Economic Studies, pp. 89-104.

Hoehn, J. P.; Randall, A. (1987): A satisfactory benefit cost indicator from contingent valuation. In Journal of Environmental Economics and Management 14 (3), pp. 226-247.

Hof, J. G.; King, D. A. (1982): On the necessity of simultaneous recreation demand equation estimation. In Land Economics 58 (4), pp. 547-552.

Horowitz, J. K.; McConnell, K. E. (2002): A review of WTA/WTP studies. In Journal of Environmental Economics and Management 44 (3), pp.426-447. DOI: 10.1006/jeem.2001.1215.

Huber, J.; McCann, J. (1982): The impact of inferential beliefs on product evaluations. In Journal of Marketing Research, pp. 324-333.

Johnson, M. B. (1966): Travel time and the price of leisure. In Economic Inquiry 4 (2), pp. 135-145.

Just, R. E.; Hueth, D. L.; Schmitz, A. (1982): Applied welfare economics and public policy. Englewood Cliffs, N.J.: Prentice-Hall.

Kahneman, D.; Tversky, A. (1979): Prospect theory: an analysis of decision under risk. In Econometrica, pp. 263-291.

Kareiva, P.; Tallis, H.; Ricketts, T. H.; Daily, G. C.; Polasky, S. (Eds.) (2011): Natural capital. Theory and practice of mapping ecosystem services. Oxford [England], New York: Oxford University Press (Oxford biology).

Kealy, M. J.; Bishop, R. C. (1986): Theoretical and empirical specifications issues in travel cost demand studies. In American Journal of Agricultural Economics 68 (3), pp. 660-667. 
Kealy, M. J.; Turner, R. W. (1993): A test of the equality of closed-ended and open-ended contingent valuations. In American Journal of Agricultural Economics 75 (2), pp. 321-331.

Kling, C. L. (1989): A note on the welfare effects of omitting substitute prices and qualities from travel cost models. In Land Economics 65 (3), pp. 290-296.

Kneese, A. V.; Smith, S. C. (Eds.) (1966): Water research. Economic analysis, water management, evaluation problems, water reallocation, political and administrative problems, hydrology and engineering, research programs and needs. [Baltimore]: Published for Resources for the Future by the Johns Hopkins Press.

Knetsch, J. L. (1963): Outdoor recreation demands and benefits. In Land Economics 39 (4), pp. 387-396.

Knetsch, J. L.; Davis, R. K. (1966): Comparisons of methods for resource evaluation. In Allen V. Kneese, Stephen C. Smith (Eds.): Water research. Economic analysis, water management, evaluation problems, water reallocation, political and administrative problems, hydrology and engineering, research programs and needs. [Baltimore]: Published for Resources for the Future by the Johns Hopkins Press.

Knetsch, J. L. (1990): Environmental-policy implications of disparities between willingness to pay and compensation demanded measures of values. In Journal of Environmental Economics and Management 18 (3), pp. 227-237.

Knetsch, J. L.; Sinden, J. A. (1984): Willingness to pay and compensation demanded experimental-evidence of an unexpected disparity in measures of value. In Quarterly Journal of Economics 99 (3), pp. 507-521.

Krutilla, J. V. (1967): Conservation reconsidered. In American Economic Review 57 (4), pp. $777-786$.

Krutilla, J. V.; Fisher, A. C. (1975): The economics of natural environments. Studies in the valuation of commodity and amenity resources. Baltimore: Published for Resources for the Future, Inc. by the Johns Hopkins University Press.

Larson, D. M. (1993): Joint recreation choices and implied values of time. In Land Economics, pp. 270-286.

Lindsay, C. M. (1969): Option demand and consumer's surplus. In The Quarterly Journal of Economics, pp. 344-346.

Long, M. F. (1967): Collective-consumption services of individual-consumption goods comment. In Quarterly Journal of Economics 81 (2), pp. 351-352.

Loomis, J.; Peterson, G.; Champ, P.; Brown, T.; Lucero, B. (1998): Paired comparison estimates of willingness to accept versus contingent valuation estimates of willingness to pay. In Journal of Economic Behavior and Organization 35 (4), pp. 501-515. 
Louviere, J. J.; Woodworth, G. (1983): Design and analysis of simulated consumer choice or allocation experiments: an approach based on aggregate data. In Journal of Marketing Research, pp. 350-367.

Madariaga, B.; McConnell, K. E. (1987): Exploring existence value. In Water Resources Research 23 (5), pp. 936-942.

Mäler, K.-G.; Vincent, J. R. (Eds.) (2005): Handbook of environmental economics. Volume 2: Valuing environmental changes. Burlington: Elsevier.

McConnell, K. E. (1980): Valuing congested recreation sites. In Journal of Environmental Economics and Management 7 (4), pp. 389-394.

McConnell, K. E. (1992): On-site time in the demand for recreation. In American Journal of Agricultural Economics 74 (4), pp. 918-925.

McConnell, K. E.; Strand, I. E. (1981): Measuring the cost of time in recreation demand analysis - an application to sportfishing. In American Journal of Agricultural Economics 63 (1), pp. 153-156.

McConnell, K. E. (1977): Congestion and willingness to pay: a study of beach use. In Land Economics, pp. 185-195.

McFadden, D. (1974): Conditional logit analysis of qualitative choice behavior. In Paul Zarembka (Ed.): Frontiers in econometrics. New York: Academic Press.

McKean, J. R.; Johnson, D. M.; Walsh, R. G. (1995): Valuing time in travel cost demand analysis: An empirical investigation. In Land Economics, pp. 96-105.

Mendelsohn, R.; Hof, J.; Peterson, G.; Johnson, R. (1992): Measuring recreation values with multiple destination trips. In American Journal of Agricultural Economics 74 (4), pp. 926933.

Mitchell, R. C.; Carson, R. T. (1981): An experiment in determining willingness to pay for national water quality improvements. In Draft Report to the US Environmental Protection Agency, Washington, DC.

Mitchell, R. C.; Carson, R. T. (1989): Using surveys to value public goods. The contingent valuation method. Washington, D.C., [Baltimore]: Resources for the Future; Distributed worldwide by the Johns Hopkins University Press.

Morrison, M. (1996): A comparison of stated preference techniques for estimating environmental values. [Canberra]: [School of Economics and Management, University College, University of New South Wales].

National Park Service, Land and Recreational Planning Division (1949): The economics of public recreation. An economic study of the monetary evaluation of recreation in the national parks. Washington. 
Navrud, S. (Ed.) (1992): Pricing the European environment. Oslo, New York: Scandinavian University Press; Oxford University Press.

Parsons, G. R.; Wilson, A. J. (1997): Incidental and joint consumption in recreation demand. In Agricultural and Resource Economics Review 26, pp. 1-6.

Pearce, D.; Atkinson, G.; Mourato, S. (2006): Cost-benefit analysis and the environment. Recent developments. Paris: OECD.

Pearce, D. W. (1993): Economic values and the natural world. 1st MIT press ed. Cambridge, Mass.: MIT Press.

Phaneuf, D. J.; Smith, V. K. (2005): Recreation demand models. In Karl-Göran Mäler, Jeffrey R. Vincent (Eds.): Handbook of environmental economics. Volume 2: Valuing environmental changes. Burlington: Elsevier, pp. 671-761.

Randall, A. (1987): Total economic value as a basis for policy. In Transactions of the American Fisheries Society 116 (3), pp. 325-335.

Randall, A.; Grunewald, O.; Johnson, S.; Ausness, R.; Pagoulatos, A. (1978): Reclaiming coal surface mines in central Appalachia: a case study of the benefits and costs. In Land Economics, pp. 472-489.

Randall, A.; Stoll, J. R. (1980): Consumer's surplus in commodity space. In The American Economic Review, pp. 449-455.

Randall, A.; Ives, B.; Eastman, C. (1974): Bidding games for valuation of aesthetic environmental improvements. In Journal of Environmental Economics and Management 1 (2), pp. 132-149.

Randall, A.; Stoll, J. R. (1983): Existence value in a total valuation framework. In Robert D. Rowe, Lauraine G. Chestnut (Eds.): Managing air quality and scenic resources at national parks and wilderness areas. Boulder, Colo.: Westview Press.

Ribaudo, M. O.; Epp, D. J. (1984): The importance of sample discrimination in using the travel cost method to estimate the benefits of improved water-quality. In Land Economics 60 (4), pp. 397-403.

Ridker, R. G. (1967): Economic costs of air pollution. Studies in measurement. New York, NY: Praeger.

Roe, B.; Boyle, K. J.; Teisl, M. F. (1996): Using conjoint analysis to derive estimates of compensating variation. In Journal of Environmental Economics and Management 31 (2), pp. $145-159$.

Rosenthal, D. H. (1987): The necessity for substitute prices in recreation demand analyses. In American Journal of Agricultural Economics 69 (4), pp. 828-837. 
Rowe, R. D.; Chestnut, L. G. (Eds.) (1983): Managing air quality and scenic resources at national parks and wilderness areas. Boulder, Colo.: Westview Press.

Russell, C. S.; Baumann, D. D. (Eds.) (2009): The evolution of water resource planning and decision making. Institute for Water Resources. Cheltenham: Elgar.

Schmalensee, R. (1972): Option demand and consumer's surplus: valuing price changes under uncertainty. In The American Economic Review 62 (5), pp. 813-824.

Schulze, W. D.; d'Arge, R. C.; Brookshire, D. S. (1981): Valuing environmental commodities: some recent experiments. In Land Economics, pp. 151-172.

Shaw, W. D. (1992): Searching for the opportunity cost of an individual's time. In Land Economics, pp. 107-115.

Smith, V. K. (1981): Congestion, travel cost recreational demand models, and benefit evaluation. In Journal of Environmental Economics and Management 8 (1), pp. 92-96.

Smith, V. K.; Desvousges, W. H.; McGivney, M. P. (1983): Estimating water-quality benefits - an econometric analysis. In Southern Economic Journal 50 (2), pp. 422-437.

Smith, V. K.; Desvousges, W. H.; McGivney, M. P. (1983): The opportunity cost of travel time in recreation demand models. In Land Economics 59 (3), pp. 259-278.

State of California (1957): Investigation of Upper Feather River Basin development. Interim report on engineering, economic, and financial feasibility of initial units. Sacramento.

The President's Water Resources Council (1962): Policies, standards, and procedures in the formulation, evaluation, and review of plans for use and development of water and related land resources. Senate Document 97. Washington D.C.

Trice, A. H.; Wood, S. E. (1958): Measurement of recreation benefits. In Land Economics XXXIV (8).

Vaughan, W. J.; Russell, C. S. (1982): Valuing a fishing day - an application of a systematic varying parameter model. In Land Economics 58 (4), pp. 450-461.

Viessman, Warren, Jr. (2009): A history of the United States water resources planning and development. In Clifford S. Russell, Duane D. Baumann (Eds.): The evolution of water resource planning and decision making. Cheltenham: Elgar, pp. 14-61.

Walsh, R. G.; Miller, N. P.; Gilliam, L. O. (1983): Congestion and willingness to pay for expansion of skiing capacity. In Land Economics, pp. 195-210.

Walsh, R. G.; Sanders, L. D.; McKean, J. R. (1990): The consumptive value of travel time on recreation trips. In Journal of Travel Research 29 (1), pp. 17-24.

Ward, F. A. (1984): Specification considerations for the price variable in travel cost demand models. In Land Economics 60 (3), pp. 301-305. 
Ward, F. A.; Beal, D. J. (2000): Valuing nature with travel cost models. A manual. Cheltenham, UK, Northhampton, Mass., USA: Edward Elgar.

Weisbrod, B. A. (1964): Collective-consumption services of individual-consumption goods. In Quarterly Journal of Economics 78 (3), pp. 471-477.

Westbrook, R. A. (1980): A rating-scale for measuring product-service satisfaction. In Journal of Marketing 44 (4), pp. 68-72.

Wetzel, J. N. (1977): Estimating the benefits of recreation under conditions of congestion. In Journal of Environmental Economics and Management 4 (3), pp. 239-246.

Willig, R. D. (1976): Consumer's surplus without apology. In The American Economic Review, pp. 589-597.

Wilman, E. A. (1987): A simple repackaging model of recreational choices. In American Journal of Agricultural Economics 69 (3), pp. 603-612.

Wilman, E. A. (1980): The value of time in recreation benefit studies. In Journal of Environmental Economics and Management 7 (3), pp. 272-286.

Zarembka, P. (Ed.) (1974): Frontiers in econometrics. New York: Academic Press. 


\section{Paper 3: Ermittlung geeigneter Flächen für die Auenwaldetablierung in Niedersachsen anhand eines ökologisch-ökonomischen Auswahlkriteriums}

\section{Einleitung}

Auen sind die (potenziell) natürlichen flussbegleitenden Gebiete, die mehr oder weniger regelmäßig von wiederkehrenden Hochwässern überflutet werden. Sie bilden mit den Fließgewässern eine untrennbare Einheit. Morphologisch und hydrologisch sind Flussauen von sehr unterschiedlichen Eigenschaften und Rahmenbedingungen ausgeprägt. Die unbehindert durch Deiche noch überflutbaren Bereiche der Aue werden als rezente Aue (oder Deichvorland), die vom Überflutungsregime abgeschnittene Bereiche als Altaue (oder Deichhinterland) bezeichnet (Abb. 1; Koenzen, 2005; Brunotte et al., 2009).

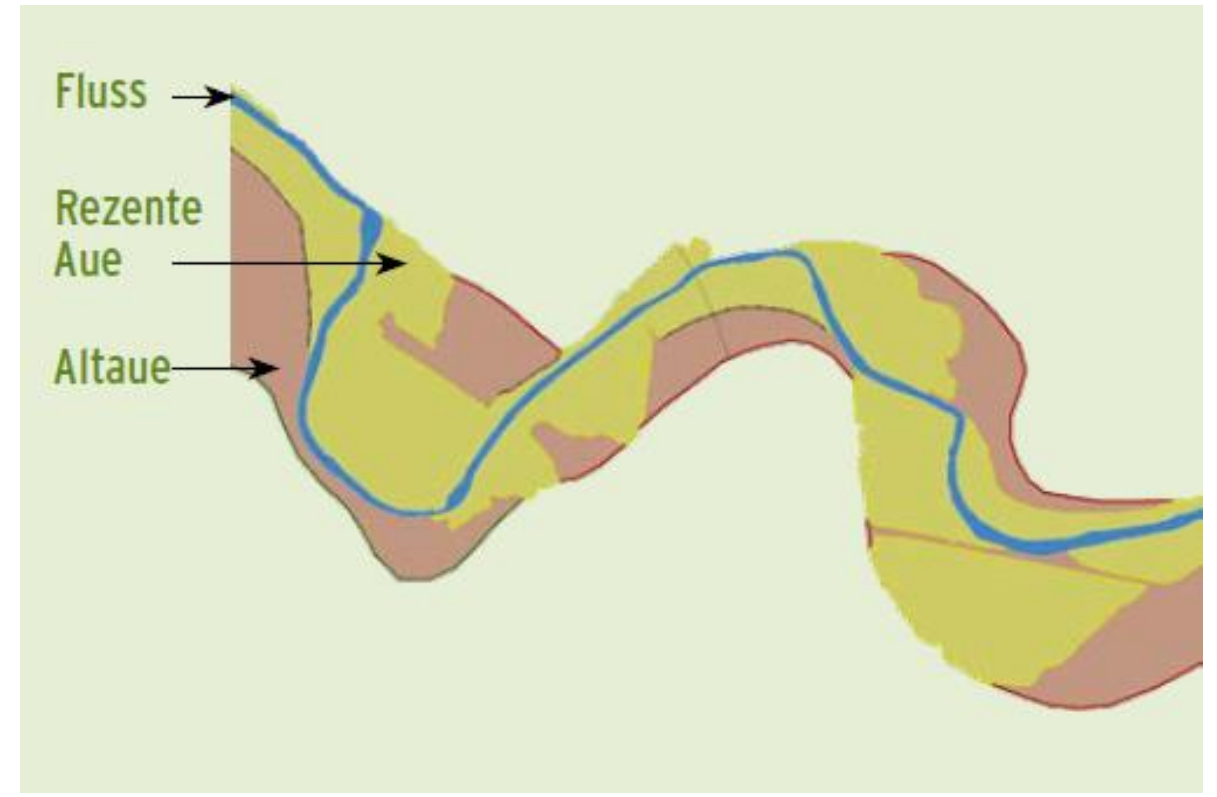

Abb. 1: Flussaue mit ihren Teileinheiten Fluss, rezente Aue und Altaue (Brunotte et al., 2009)

Die Pflanzengesellschaft der Flussauen wird häufig als azonale Vegetation bezeichnet, die insbesondere von der Wasserführung des Flusses abhängt. Die Auenwälder zählen zu den Waldtypen mit der höchsten Baumartenvielfalt. Einst waren sie in der ursprünglichen Naturlandschaft Mitteleuropas weit verbreitet, aber heutzutage gehören zu den seltenen 
Waldtypen. Die typische Gliederung der Vegetation wird in Abbildung 2 schematisch am Beispiel des Querprofils eines Flusses im Alpenvorland vom Gewässerufer bis zum Rand der Aue dargestellt (Ellenberg et al., 2010).

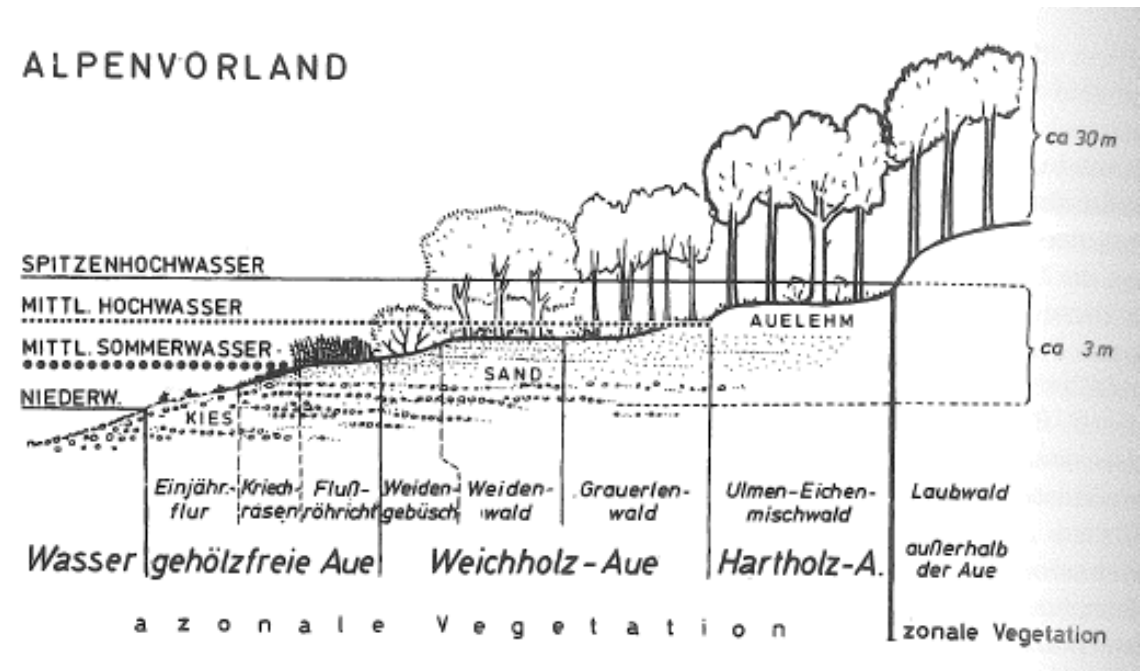

Abb. 2: Auenvegetation am Mittellauf eines Flusses im Alpenvorland (Ellenberg et al., 2010)

Für die Erfassung und Bewertung des Auenzustandes gibt es einen bundesweiten Überblick. Insgesamt beträgt die Länge der 79 Flüsse Deutschlands $10.276 \mathrm{~km}$ und die Fläche der Auenkulisse $15.533 \mathrm{~km}^{2}$, wobei nur Flüsse mit einem Einzugsgebiet ab $1.000 \mathrm{~km}^{2}$ aufgenommen, quellnähere Bereiche und Tidebereiche der Flüsse nicht untersucht wurden. Bei der Mehrzahl der Flüsse haben die intensive Nutzung der Auen, der Deichbau, der Gewässerausbau und die Stauregulierungen $\mathrm{zu}$ erheblichen Verlusten an natürlichem Überschwemmungsgebiete und zu beträchtlichen Veränderungen des Auenzustandes geführt. Aktuell können nur noch rund ein Drittel bei großen Hochwasserereignissen überflutet werden. Die rezenten Auen an den untersuchten Flüssen werden zu einem Drittel intensiv als Acker-, Siedlungs-, Verkehrs- und Gewerbeflächen genutzt, 46\% als Grünland bewirtschaftet, nur 13\% sind Wälder. Die Nutzungsverhältnisse der Altauen weisen mit knapp $50 \%$ einen deutlich höheren Anteil an Ackerflächen auf, der auf die aus landwirtschaftlicher Sicht 
günstigeren Bewirtschaftungsverhältnisse zurückgeführt werden kann. Der Anteil an Siedlungsflächen in den Altauen beträgt rund 16\% (Brunotte et al., 2009).

Die Bewertung des Auenzustandes wird in fünf Klassen vorgenommen. Für jede Auenzustandsklasse werden mögliche Ausprägungen beschrieben, die Angaben zu den Überflutungsverhältnissen, zum Ausbaugrad des Gewässers und zur Intensität der Flächennutzung umfassen (Abb.3; Brunotte et al., 2009).

\begin{tabular}{|c|c|c|}
\hline \multicolumn{2}{|c|}{ Klasse } & Ausprägungen \\
\hline 1 & sehr gering verändert & $\begin{array}{l}\text { Auen von Überflutung durch Gewăsserausbau und/oder Hochwasserschutzmaßnahmen nicht oder nur in } \\
\text { sehr geringem Maße abgekoppelt } \\
\text { Gewăsser in der Regel mit sehr geringem Ausbaugrad, selten regelprofilliert, mit sehr hohem Über- } \\
\text { flutungspotenzial } \\
\text { Vorherrschend keine oder sehr extensive Flăchennutzung, zumeist Wald, Feuchtgebiete und vereinzelt } \\
\text { Grünland }\end{array}$ \\
\hline 2 & gering verändert & $\begin{array}{l}\text { Auen von Überflutung durch Gewăsserausbau und/oder Hochwasserschutzmaßnahmen in geringem } \\
\text { Maße abgekoppelt } \\
\text { Ausbaugrad unterschiedlich, z. T. regelprofiliert, aber in der Regel mit hohem Überflutungspotenzial } \\
\text { Vorherrschend extensive Flăchennutzung, zumeist Wald, Feuchtgebiete und Grünland }\end{array}$ \\
\hline 3 & deutlich verăndert & $\begin{array}{l}\text { Auen von Überflutung durch Gewăsserausbau und/oder Hochwasserschutzmaßnahmen teilweise } \\
\text { abgekoppelt } \\
\text { Gewăsser in der Regel ausgebaut, jedoch mit Überflutungspotenzial } \\
\text { Wechselnde Flăchennutzungsintensităten }\end{array}$ \\
\hline 4 & stark verăndert & $\begin{array}{l}\text { Auen von Überflutung durch Gewăsserausbau und/oder Hochwasserschutzmaßnahmen weitgehend } \\
\text { abgekoppelt } \\
\text { Gewăsser in der Regel ausgebaut, teilweise gestaut } \\
\text { Intensive Flächennutzung, vorherrschend intensive Landwirtschaft und Siedlungen }\end{array}$ \\
\hline 5 & sehr stark verändert & $\begin{array}{l}\text { Auen von Überflutung durch Gewăsserausbau und/oder Hochwasserschutzmaßnahmen abgekoppelt } \\
\text { Gewăsser in der Regel stark ausgebaut, hăufig gestaut } \\
\text { Intensive Flăchennutzung, zumeist mit höheren Siedlungsanteilen }\end{array}$ \\
\hline
\end{tabular}

Abb. 3: Auenzustandsklassen (Brunotte et al., 2009)

Von den bewerteten Auenabschnitten werden weniger als $1 \%$ der rezenten Auen in der Klasse 1 (sehr gering verändert) und $9 \%$ in der Klasse 2 (gering verändert) eingestuft. 36\% der rezenten Auen werden der Klasse 3 (deutlich verändert) zugeordnet, besitzen aber gleichermaßen noch „Auencharakter“. Über die Hälfte der rezenten Auen befinden sich dennoch in den Zustandsklassen 4 (stark verändert) und 5 (sehr stark verändert). Im Vergleich 
dazu überwiegen bei Altauen mit rund $80 \%$ die Klassen 4 und 5 (Abb. 4; Brunotte et al., 2009).

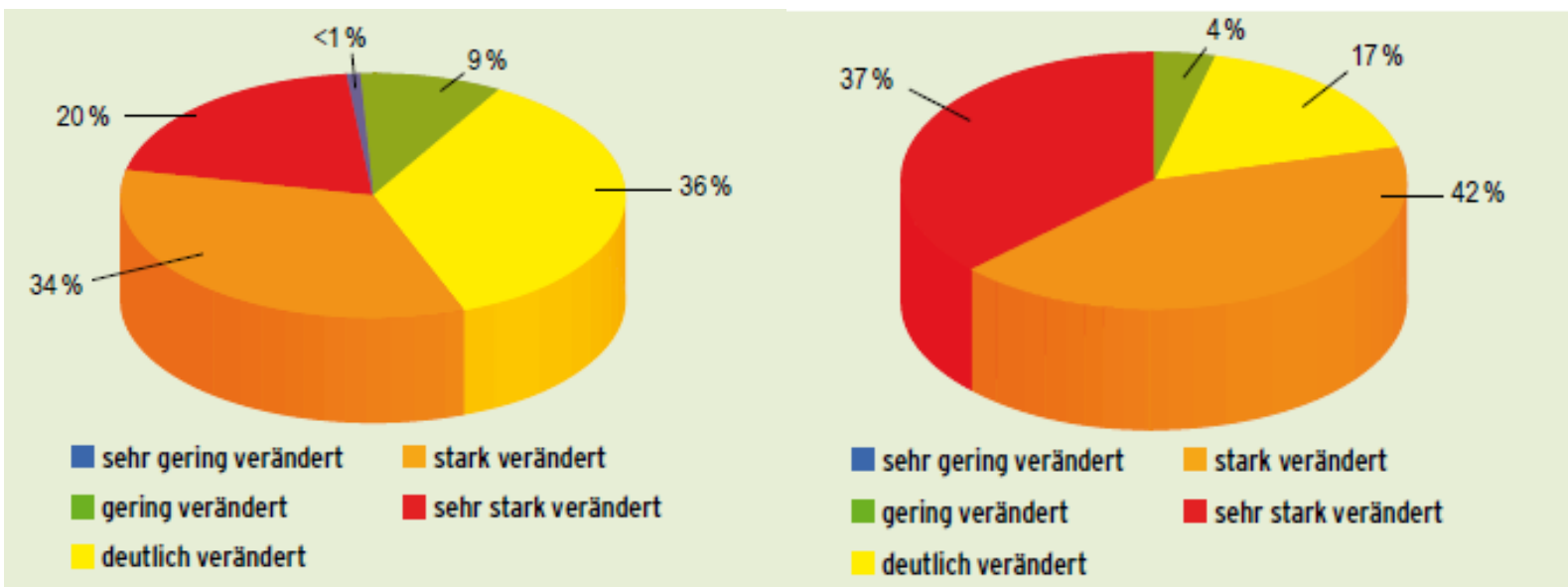

Abb. 4: Verteilung der Bewertungsklassen für die rezenten Auen und Altauen (Brunotte et al., 2009)

Durch die Erläuterung der ursprünglichen Vegetation und des Auenzustandes wird deutlich, dass Flussauen in drei Aspekten renaturiert werden können. Im hydrologischen Sinne sollten die ausgebauten und gestauten Gewässer in einen naturnäheren Zustand versetzt werden. Im morphologischen Sinne sollte eine Überflutung der Aue durch eine Wiederanbindung ermöglicht werden. Das bedeutet, dass die künstlichen Hochwasserschutzmaßnahmen, Deiche in den meisten Fällen, zurückverlegt oder sogar gänzlich abgerissen werden sollen, damit die Altaue wieder überflutet werden kann und mehr natürliche Überschwemmungsflächen zurück gewonnen werden (Grossmann et al., 2010). Im biologischen Sinne sollte die Vegetation der Auen in ihre ursprünglichen Formen, insbesondere Weichholz- und Hartholzauwälder, umgewandelt werden (Mosner et al., 2010). Der Fokus dieser Arbeit liegt auf der dritten Art der Auenrenaturierung, und zwar die Auenwaldetablierung.

Auenwälder tragen nicht nur zum Hochwasserschutz, zur Nährstoffretention, Kohlenstoffspeicherung bei, sondern sind auch Lebensräume und Wanderungskorridore für 
Pflanzen und Tiere (Biodiversität). Allerdings besitzt ein Großteil der ca. 61.000 ha umfassenden Waldflächen in rezenten Auen keinen Auenwaldcharakter mehr; lediglich ca. 5.700 ha naturnahe Hartholzauenwälder sind heute noch erhalten geblieben, was weniger als $1 \%$ des ursprünglichen Bestandes entspricht (Brunotte et al., 2009). Die Lebensraumtypen „Weichholzauenwälder“ und „Hartholzauenwälder“, die im Anhang I der Fauna-FloraHabitat-Richtlinie aufgelistet sind, befinden sich in einem ungünstigen oder sogar schlechten Zustand (BMU, 2011). Die Wiederherstellung und Etablierung von Auenwäldern wird durch die nationale Strategie zur biologischen Vielfalt und die deutsche Anpassungsstrategie an den Klimawandel angestrebt und in Anpassungsmaßnahmen „Renaturierung von Auenlandschaften“ umgesetzt (BMU, 2007; BMU, 2008; Tröltzsch et al., 2012). Außerdem verfolgt das niedersächsische Auenprogramm das Ziel, dass die Fließgewässer unter besonderer Berücksichtigung der Auwälder renaturiert und entwickelt werden sollen (NMUEK, 2012).

Vor diesem Hintergrund stellt sich die Frage, wo mit den knappen öffentlichen Geldern der größte Nettonutzen einer Auenwaldetablierung erzielt werden kann. Das Ziel der Arbeit ist es daher, geeignete Flächen der Flussgebiete Niedersachsens für die Auenwaldetablierung zu ermitteln, die Effizienz potentieller Flächen anhand des ökologisch-ökonomischen Auswahlkriteriums zu vergleichen und der Politik bzw. der Verwaltung die durch Geoinformationssystem (GIS) veranschaulichten Informationen darüber bereitzustellen.

\section{Methodik und Datengrundlage}

Die Ermittlung geeigneter Flächen zur Auenwaldetablierung wird durch ein ökologischökonomisches Auswahlkriterium realisiert, das aus ökonomischer Effizienz und vielfältigen 
ökologischen Faktoren besteht. Für die Ermittlung der ökonomischen Effizienz wird die Relation des Gegenwartswertes des gebietsweise variierenden volkswirtschaftlichen Nettonutzens der Auenwaldetablierung pro ha (GGW) multipliziert mit der zu etablierenden Flächengröße des Auenwalds (F) zu den beantragten Beihilfen (B) berechnet, und zwar Effizienz $=\mathrm{GGW} * \mathrm{~F} / \mathrm{B}$. Der Gegenwartswert ergibt sich aus Diskontierung, bei der die Laufzeit und die Diskontrate jeweils auf 20 Jahre und drei Prozent (UBA, 2012a) festgelegt werden.

Um den volkswirtschaftlichen Nettonutzen zu berechnen, werden folgenden Kosten- und Nutzenkomponenten betrachtet: Kosten für Flächenankauf und Anpflanzung der Waldbestände, Nutzen des Hochwasserschutzes, der Nährstoffretention, der Kohlenstoffspeicherung und der Biodiversität. Es wird davon ausgegangen, dass die Gesamtkosten zu Beginn des Projektes anfallen und die jährlichen Gesamtnutzen aus dem Auenwald ab dem elften Jahr auftreten, da der Auenwald sich erst in zehn Jahren nach der Anpflanzung etablieren und somit seine ökologischen Funktionen ausüben kann. In Niedersachsen steht keine volle Finanzierung zur Verfügung, sondern es wird eine bestimmte Beihilfe beantragt. Im vereinfachten Fall, in dem die zu etablierende Flächengröße extern festgelegt wird und die beantragten Beihilfen als gleich unterstellt sind, ist der Gegenwartswert des volkswirtschaftlichen Nettonutzens einer bestimmten Fläche zu berïcksichtigen.

Außer der ökonomischen Perspektive wird die ökologische Perspektive berücksichtigt. Hier sind der Landnutzungstyp, der Bereich der Flussaue, der Auenzustand und die Flächengröße die notwendigen ökologischen Faktoren und der prioritäre Bereich, die Hochwassergefahr und 
die Habitatqualität optionale Faktoren. Abschließend werden die Ergebnisse durch ein Geoinformationssystem (GIS) veranschaulicht.

Folgende Daten dienen als Grundlage für diese Arbeit:

- Verwaltungsgebiete 1:250.000 (BKG, 2013)

- Digitales Landbedeckungsmodell für Deutschland (BKG, 2011)

- Flussauen und Auenzustandsbewertung (BfN, 2011)

- Ökosystemfunktionen von Flussauen (BfN, 2012)

- Gebietskulisse niedersächsisches Auenprogramms (NLWKN, 2012)

- Hochwassergefahrengebiete bei $\mathrm{HQ}_{100}$ (NLWKN, 2013)

- Kaufwerte für landwirtschaftliche Grundstücke (LSN, 2015)

\section{Vorgehensweise und Ergebnis}

\section{1 Ökologische Faktoren}

(1) Landnutzung: Ackerland oder Grünland (nötig)

Aufgrund der Datenverfügbarkeit und praktischen Durchführbarkeit werden nur die aktuell als Ackerland oder Grünland genutzten Flächen in Betracht gezogen (Koenzen 2013; Abb. 5). 


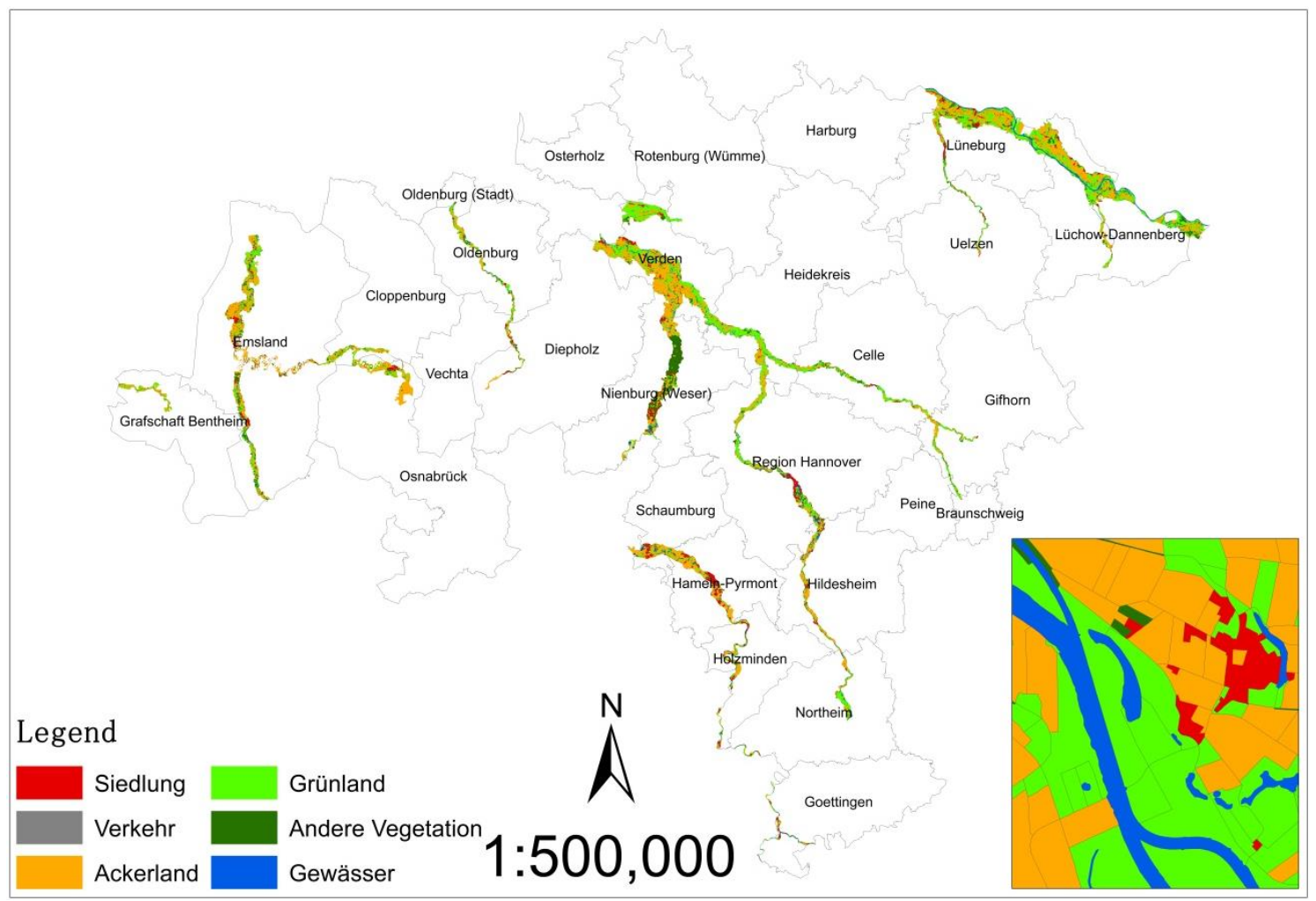

Abb. 5: Karte der Landnutzungen in den Flussauen

(2) Teil der Flussaue: rezente Aue (nötig)

Dabei ist die Überlegung, dass die Etablierung des Auenwalds nur in den rezenten Auen, die noch vom Hochwasser erreichbar sind, möglich und sinnvoll ist (Abb. 6). 


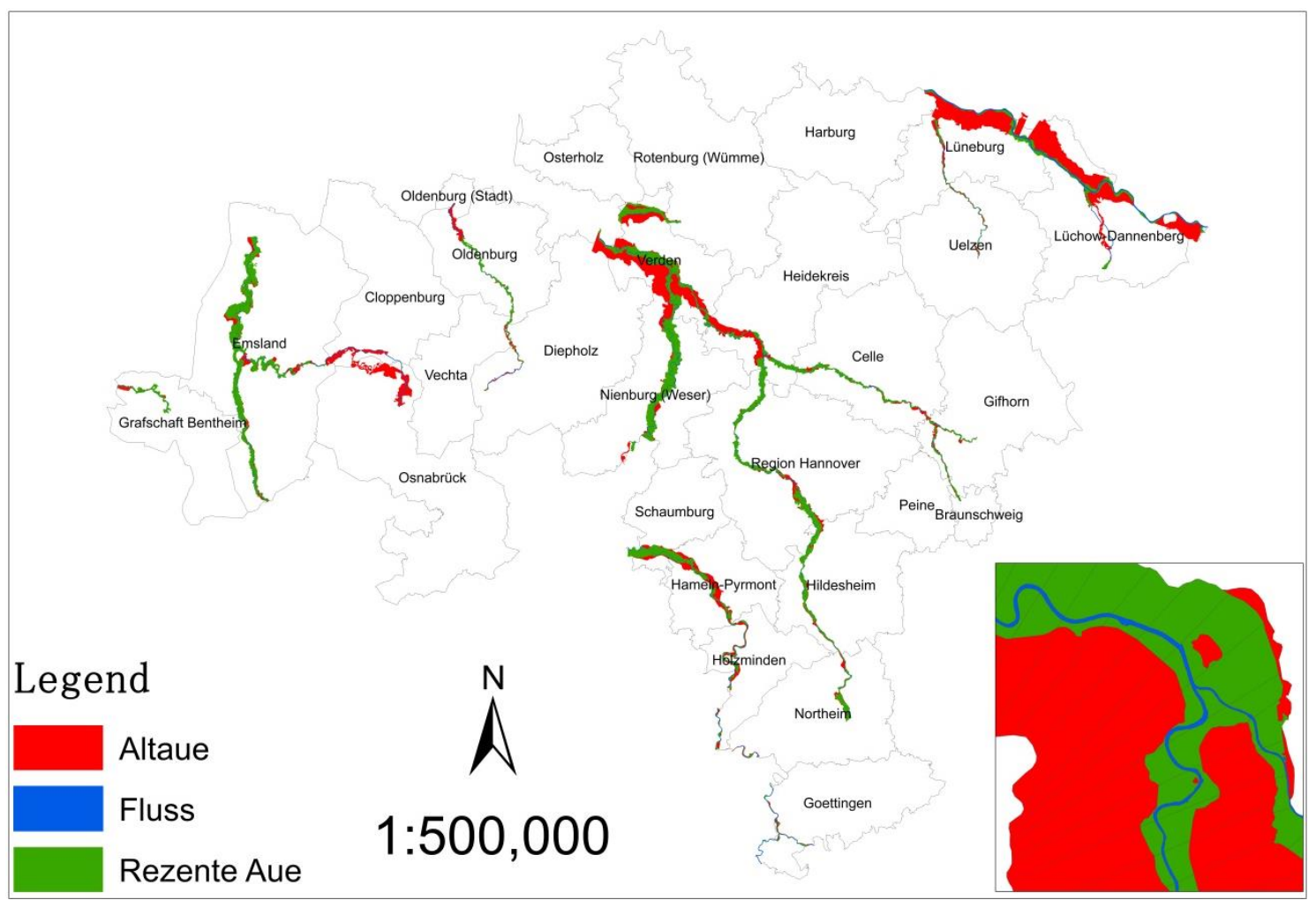

Abb. 6: Karte der Flussauen in Niedersachsen

(3) Zustand rezenter Auen: Klasse 1, 2 und 3 (nötig)

Das Bewertungsverfahren für den Auenzustand bezieht sich auf drei funktionale Einheiten, und zwar (a) Morphodynamik, Auenrelief und Auengewässer, (b) Hydrodynamik, Abfluss und Überflutung, und (c) Vegetation und Flächennutzung. Die Bewertung erfolgt auf Basis von 1-km-Auensegmenten jeweils für die rechte und linke Aue. Die Gesamtbewertung des jeweiligen Segmentes entsteht durch Verrechnung der drei funktionalen Einheiten. Die „Konnektivität“ als Bonus berücksichtigt den Anteil von Flächen mit extensiver Flächennutzung bzw. auentypischen Biotoptypen, deren Flächengröße sowie die Lage naturnäherer Auensegmente zueinander Rückstaubeeinträchtigte Segmente werden wegen der starken Veränderungen der Standortbedingungen in Auen, die zu weitreichenden Wandlungen 
der hydromorphologischen Prozesse sowie der Abfluss- und Grundwasserverhältnisse führen, mit einem Malus versehen (Brunotte et al., 2009).

Betrachtet werden die Auen mit den Zustandsklassen 1, 2 und 3, weil sie noch überflutet werden können und somit die Wiederherstellung eines typischen Auenwalds möglich ist. Es wird davon ausgegangen, dass die Auenwaldetablierung zur weiteren Verbesserung des Auenzustands beitragen kann (Abb. 7).

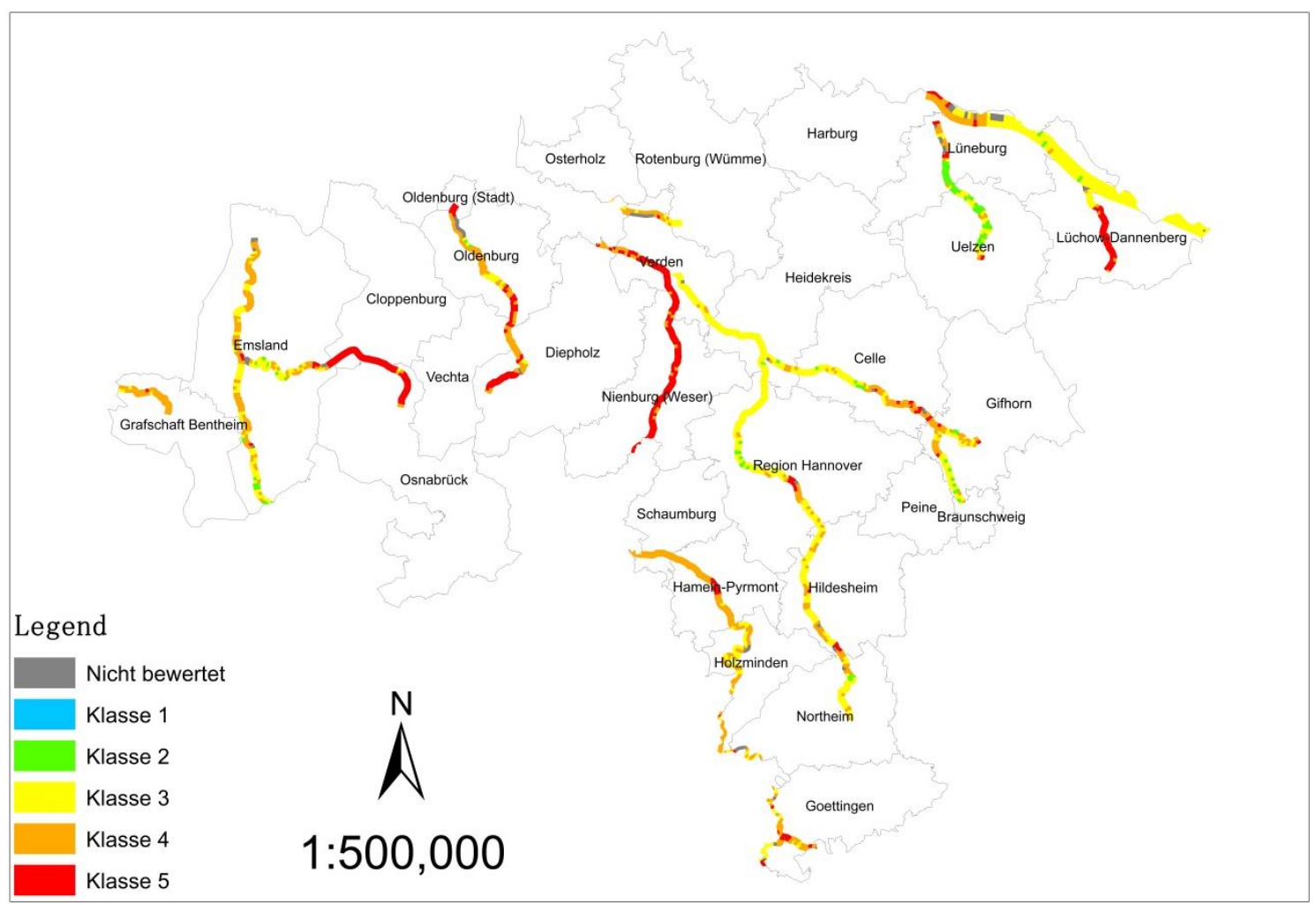

Abb. 7: Karte des Zustands von rezenten Auen

(4) Flächengröße: mindestens 1,5 ha (nötig)

Die Mindestgröße für Pflanzflächen wird auf 1,5 ha festgelegt, um zumindest einige ökologische Funktionen von Auwäldern zu gewährleisten (Mosner et al., 2010).

(5) Prioritäre Bereiche niedersächsischen Auenprogramms (optional) 
Die prioritären Bereiche stellen auentypische Flächen dar, die Bestandteil von Natura 2000Gebieten, und/oder gleichzeitig die vom Bundesnaturschutzgesetz geschützten Gebiete sind (Storm, 2011; NMUEK, 2012). Dabei ist es die Überlegung, dass die Wiederherstellung von Auwäldern in solchen Gebieten zum Erhalt der biologischen Vielfalt, zur Verbesserung der Leistungs- und Funktionsfähigkeit des Naturhaushalts beitragen kann (Abb. 8).

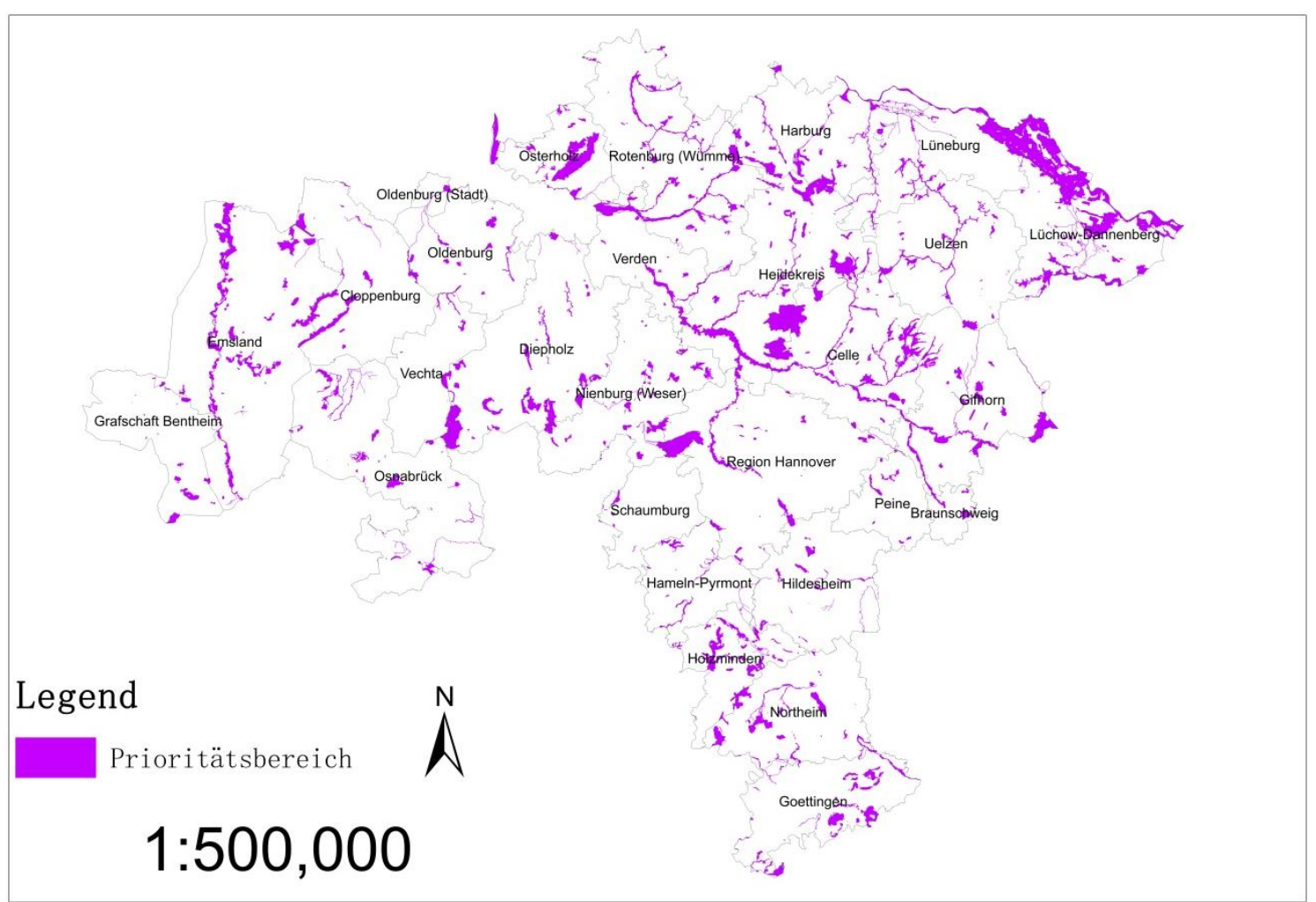

Abb. 8: Prioritäre Bereiche niedersächsischen Auenprogramms

(6) Wassertiefe bei $\mathrm{HQ}_{100}$ : > 1m (optional)

Mit der Verabschiedung der Europäischen Hochwasserrisikomanagement-Richtlinie im Jahr 2007 ist für die Mitgliedsstaaten der EU ein gesetzlicher Rahmen geschaffen (Jüpner, 2013; Brombach, 2013). Im Zuge deren Umsetzung hat der Niedersächsische Landesbetrieb für Wasserwirtschaft, Küsten- und Naturschutz (NLWKN) Hochwassergefahrenkarten und Hochwasserrisikokarten für das Küstengebiet und die 29 Flüsse in Niedersachsen erstellt. Die 
Hochwassergefahrenkarten stellen die mögliche Ausdehnung und Wassertiefe der Überflutung für jeweils ein Hochwasser mit hoher $\left(\mathrm{HQ}_{\text {häufig }}\right)$, mittlerer $\left(\mathrm{HQ}_{100}\right)$ und niedriger $\left(\mathrm{HQ}_{\text {extrem}}\right)$ Wahrscheinlichkeit dar. Das $\mathrm{HQ}_{100}$ ist der Hochwasserabfluss, der statistisch

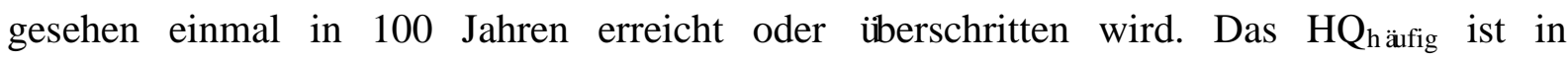
Niedersachsen in der Regel das $\mathrm{HQ}_{20}$ bzw. $\mathrm{HQ}_{25}$, also der Hochwasserabfluss, der statistisch gesehen einmal in 20 bzw. 25 Jahren erreicht oder überschritten wird. Das HQextrem wird in Niedersachsen durch das Multiplizieren vom $\mathrm{HQ}_{100}$ mit dem Faktor 1,3 ermittelt, und ist in der Regel größer als ein $\mathrm{HQ}_{200}(\mathrm{NLWKN})$. Hier wird die Wassertiefe im $\mathrm{HQ}_{100}$ als optionaler Faktor angewendet. Die Wassertiefen sind in fünf Klassen unterteilt: $0-0,5 \mathrm{~m},>0,5-1 \mathrm{~m},>$ $1-2 \mathrm{~m},>2-4 \mathrm{~m}$ und $>4 \mathrm{~m}$. Es wird davon ausgegangen, dass die Flächen mit höherer Wassertiefe beim Hochwasser unter größerem Risiko stehen und die Auenwaldetablierung auf diese Flächen sinnvoller ist (Abb. 9).

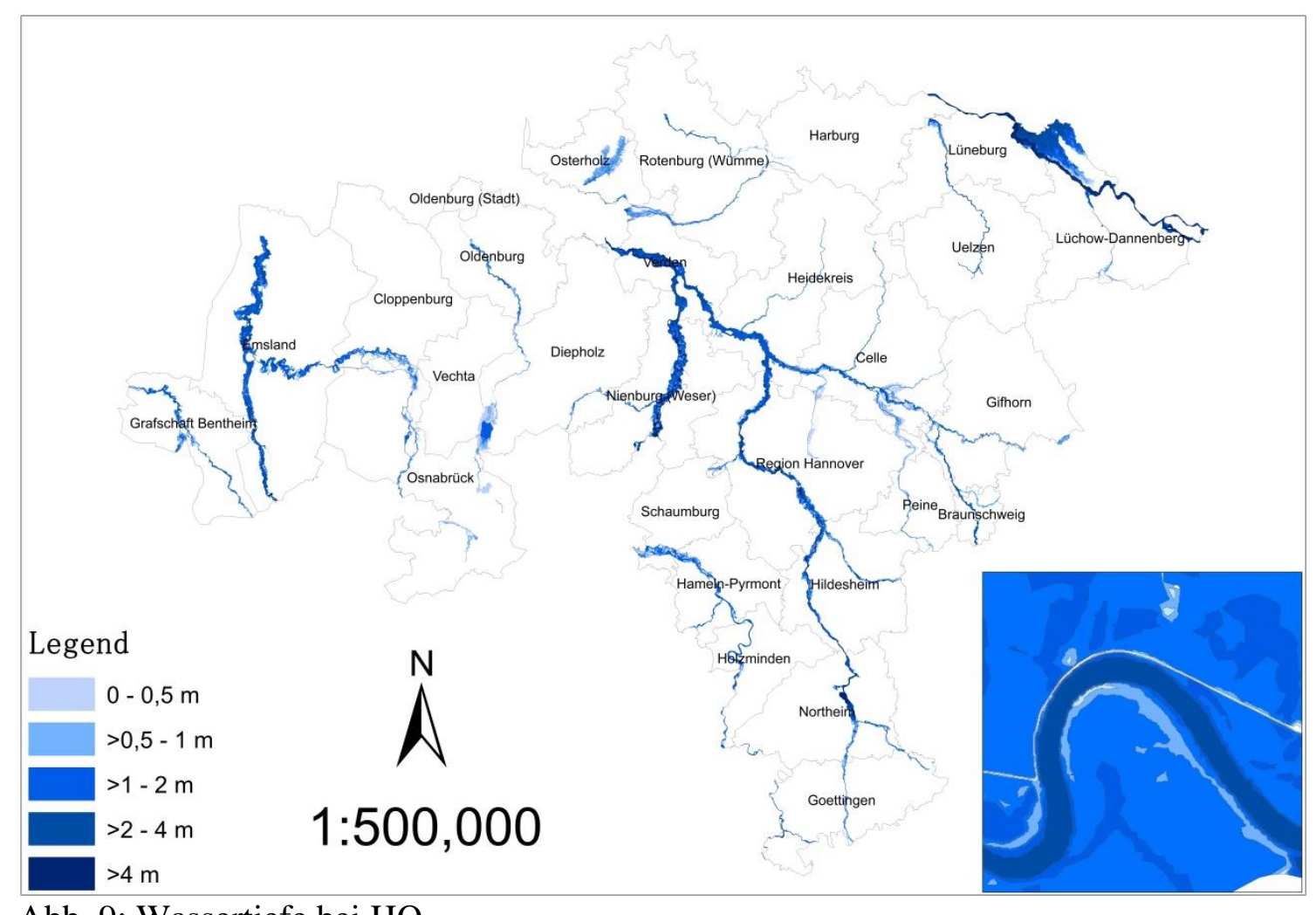

Abb. 9: Wassertiefe bei $\mathrm{HQ}_{100}$ 
(7) Habitatindex: 1, 2 und 3 (optional)

Einen weiteren Faktor bildet der von Scholz et al. (2012) entwickelte Habitatindex. Unter der Habitatfunktion wird die Bedeutung einer Aue für die naturraumtypische Vielfalt der Arten und Lebensräume der Natur- und Kulturlandschaft verstanden. Für diesen Zweck werden vier Merkmale ausgewählt, die mehr oder weniger flächendeckend für eine bundesweite Auswertung zur Verfügung stehen und sich jeweils für die 1-km-Auensegmente der rezenten Auen darstellen lassen.

- Flächenanteil an Natura 2000-Gebieten.

Die Natura 2000-Gebiete sind als Schutzgebiete nach der Fauna-Flora-Habitat-Richtlinie und der Vogelschutzrichtlinie bundesweit nach einheitlichen Kriterien ausgewiesen. Es wird angenommen, dass größere Populationen auentypischer Arten und mehr Lebensraumtypen in Natura 2000-Gebieten in den rezenten Auen anzutreffen sind als in denen ohne diesen Schutzstatus. Daher kann der Flächenanteil an Natura 2000-Gebieten als eine Maßzahl für die auentypische Vielfalt gelten.

- Landnutzungsintensität.

Bei der Klassifizierung der Landnutzungsintensität ist davon auszugehen, dass die Landnutzungen Wald, Gewässer und Feuchtgebiet die geringste Nutzungsintensität aufweisen, Grünland eine mittlere sowie Ackerland und Siedlung eine hohe Intensität.

- Flächenanteil an Feuchtlebensräumen und geschützten Biotopen.

Dieses Merkmal gibt Auskunft über das quantitative und qualitative Vorkommen von auentypischen Biotopen.

- Rückstau. 
Die durch Rückstau beeinflussten Flussabschnitte und Auen weisen eine Vielzahl an Natura 2000-Gebieten mit naturschutzfachlich bedeutsamen, auenähnlichen Lebensräumen auf. Allerdings besitzen sie wegen der fehlenden bzw. eingeschränkten Auendynamik nicht den gleichen ökologischen und naturschutzfachlichen Wert wie auentypische Lebensräume an frei fließenden Flussabschnitten. Es ist davon auszugehen, dass durch Stauwerke beeinträchtigte Flussauen in der Regel eine eingeschränkte auentypische Vielfalt aufweisen.

Auf Basis dieser Merkmale, die jeweils in fünf Klassen in den 1-km-Auensegmenten eingeteilt werden, ist ein integrierender Index für die Habitatfunktion zu berechnen. Wie in Abbildung 7 dargestellt, wird bei der Berechnung des Habitatindexes so vorgegangen: Die Werte der ersten drei Merkmale werden gemittelt und auf eine ganze Zahl gerundet. Wenn dieser Wert zwischen 1 und 4 liegt und das Merkmal „Rückstau“ im 1-km-Segment vorhanden ist, wird der Indexwert um 1 Stufe abgewertet, um die Beeinträchtigungen des Rückstaus auf die Lebensraumqualität zu berücksichtigen (Scholz et al., 2012).

Die Bewertung der Habitatfunktion ergänzt den Auenzustand und wird als konkretere Darstellung der dritten funktionalen Einheit des Auenzustands angesehen. Entsprechend ist die Annahme, dass es für günstiger gehalten wird, einen Auenwald auf der Fläche mit besserer Habitatfunktion (kleinerer Habitatindex) zu etablieren (Abb. 10). 


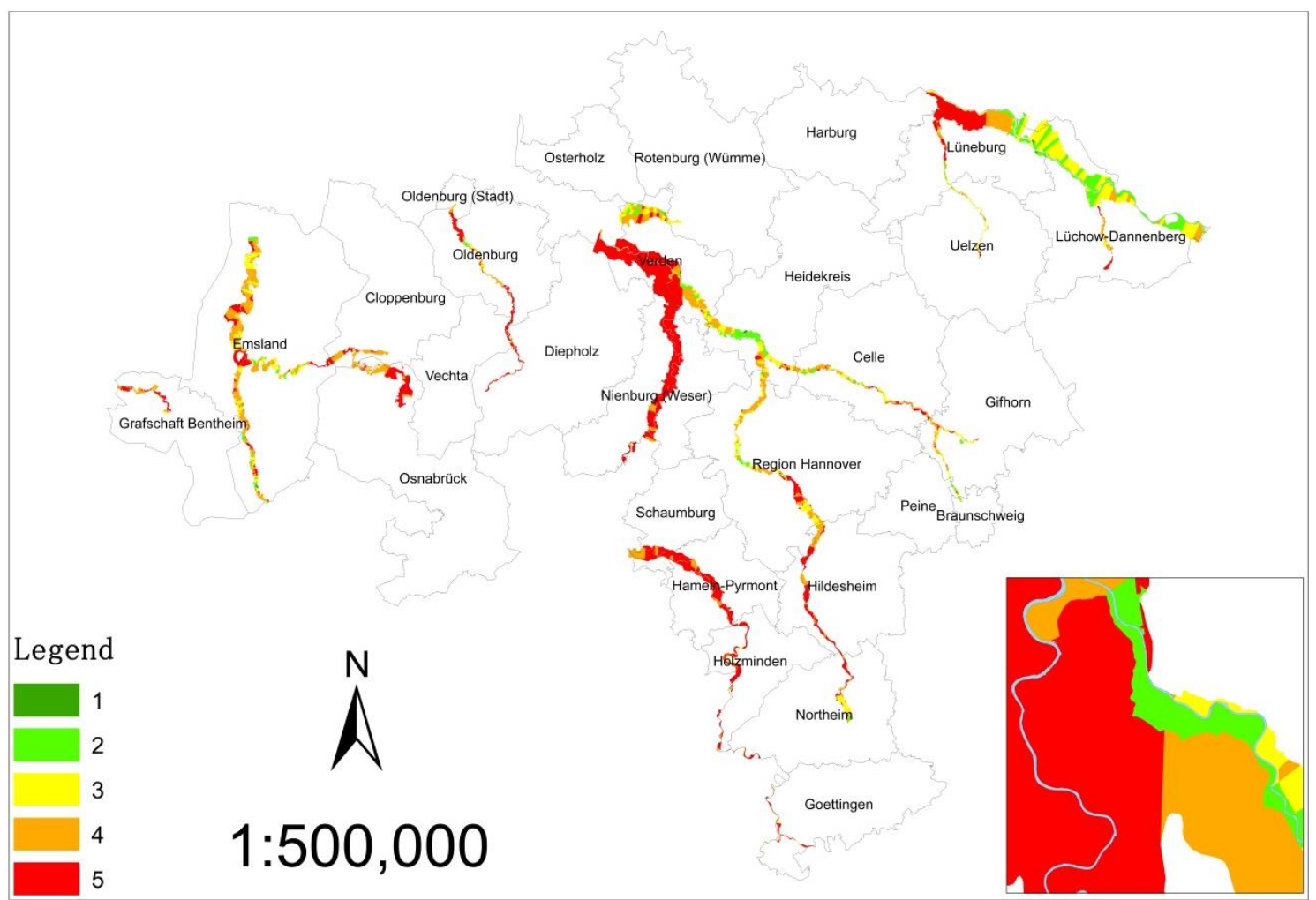

Abb. 10: Habitatindex der Flussauen

\subsection{Kosten I: Ankauf von Flächen}

Aufgrund der Datenverfügbarkeit und praktischen Durchführbarkeit werden nur die aktuell als Ackerland oder Grünland genutzten Flächen in Betracht gezogen (Koenzen, 2013). Die Hauptkosten sind die Entschädigungszahlungen für die bisherigen Nutzer bzw. der Kauf von Flächen. Dabei wird davon ausgegangen, dass sich die Flächen zum Großteil in privatem Besitz befinden. Für Niedersachsen liegen Kaufwerte für landwirtschaftliche Grundstücke mit Unterteilung von Ackerland und Grünland auf die Landkreisebene aus dem Jahr 2015 vor (Tab. 1; LSN, 2015). Dazu muss noch angenommen werden, dass diese Kaufwerte die Opportunitätskosten der landwirtschaftlichen Flächen abdecken.

Tab. 1: Kaufwerte des Acker- und Grünlandes in den Landkreisen Niedersachsens im Jahr 2015 (eigene Darstellung nach LSN, 2015)

\begin{tabular}{|l|l|l|}
\hline Landkreis & Ackerland (€/ha) & Grünland (€/ha) \\
\hline
\end{tabular}




\begin{tabular}{|l|l|l|}
\hline Braunschweig & 36812 & 17682 \\
\hline Celle & 20368 & 13522 \\
\hline Cloppenburg & 78624 & 32254 \\
\hline Diepholz & 47358 & 26168 \\
\hline Emsland & 61723 & 27839 \\
\hline Gifhorn & 25178 & 10722 \\
\hline Göttingen & 19755 & 8554 \\
\hline Grafschaft Bentheim & 60882 & 44830 \\
\hline Hameln-Pyrmont & 29186 & 13134 \\
\hline Harburg & 29186 & 13134 \\
\hline Heidekreis & 26226 & 14935 \\
\hline Hildesheim & 34562 & 12134 \\
\hline Holzminden & 29186 & 13134 \\
\hline Lüchow-Dannenberg & 17805 & 10775 \\
\hline Lüneburg & 20927 & 15386 \\
\hline Nienburg (Weser) & 31244 & 18032 \\
\hline Northeim & 22104 & 8244 \\
\hline Oldenburg & 55620 & 25142 \\
\hline Oldenburg (Stadt) & $30654 *$ & 21258 \\
\hline Osnabrück & 62291 & 25567 \\
\hline Osterholz & 21528 & 14515 \\
\hline Peine & 41094 & 15991 \\
\hline Region Hannover & 41094 & 15991 \\
\hline Rotenburg (Wümme) & 32216 & 16469 \\
\hline Schaumburg & 31979 & 14480 \\
\hline Uelzen & 19474 & 16666 \\
\hline Vechta & 91623 & 36142 \\
\hline Verden & 31318 & 17147 \\
\hline
\end{tabular}

* Daten aus dem Jahr 2013

\subsection{Kosten II: Anpflanzung von Auenwaldbestand}

Weiterhin sind Kosten für die Pflanzung von Auenwaldbeständen einzurechnen. Da die Vegetation sich sukzessiv auf angrenzende Flächen ausbreiten kann, ist es nicht nötig, die Fläche vollständig zu bepflanzen, um einen Auenwald zu entwickeln. Es wird eingeschätzt, dass die Kosten $200 € /$ ha betragen (Tröltzsch et al., 2012). 


\subsection{Nutzen I: Hochwasserschutz}

Hochwasser ist eine Komponente des natürlichen Wasserkreislaufs und daher nicht zu vermeiden. In erster Linie wird Hochwasser durch Niederschlagsereignisse verursacht. Ein Teil des Niederschlags wird zu Beginn auf Pflanzen und auf der Bodenoberfläche zurückgehalten. Größere Teile entweder laufen direkt oberflächig ab, versickern und werden im Boden zwischen gespeichert, oder fließen dem Grundwasserleiter zu. Die Erhöhung des Oberflächen- und Grundwasserabflusses führt in den Fließgewässern zu steigenden Wasserständen (Patt und Jüpner, 2013). Wie Abb. 5 darstellt, besteht die Hochwasserentstehung aus drei Prozessen: Abflussbildungs-, Abflusskonzentrations- und Fließprozess im offenen Gerinne. Für den Abflussbildungsprozess relevant sind die Niederschlagsintensität, die Bodeneigenschaften und die Erdoberfläche bzw. die Landnutzung (Disse, 2013).

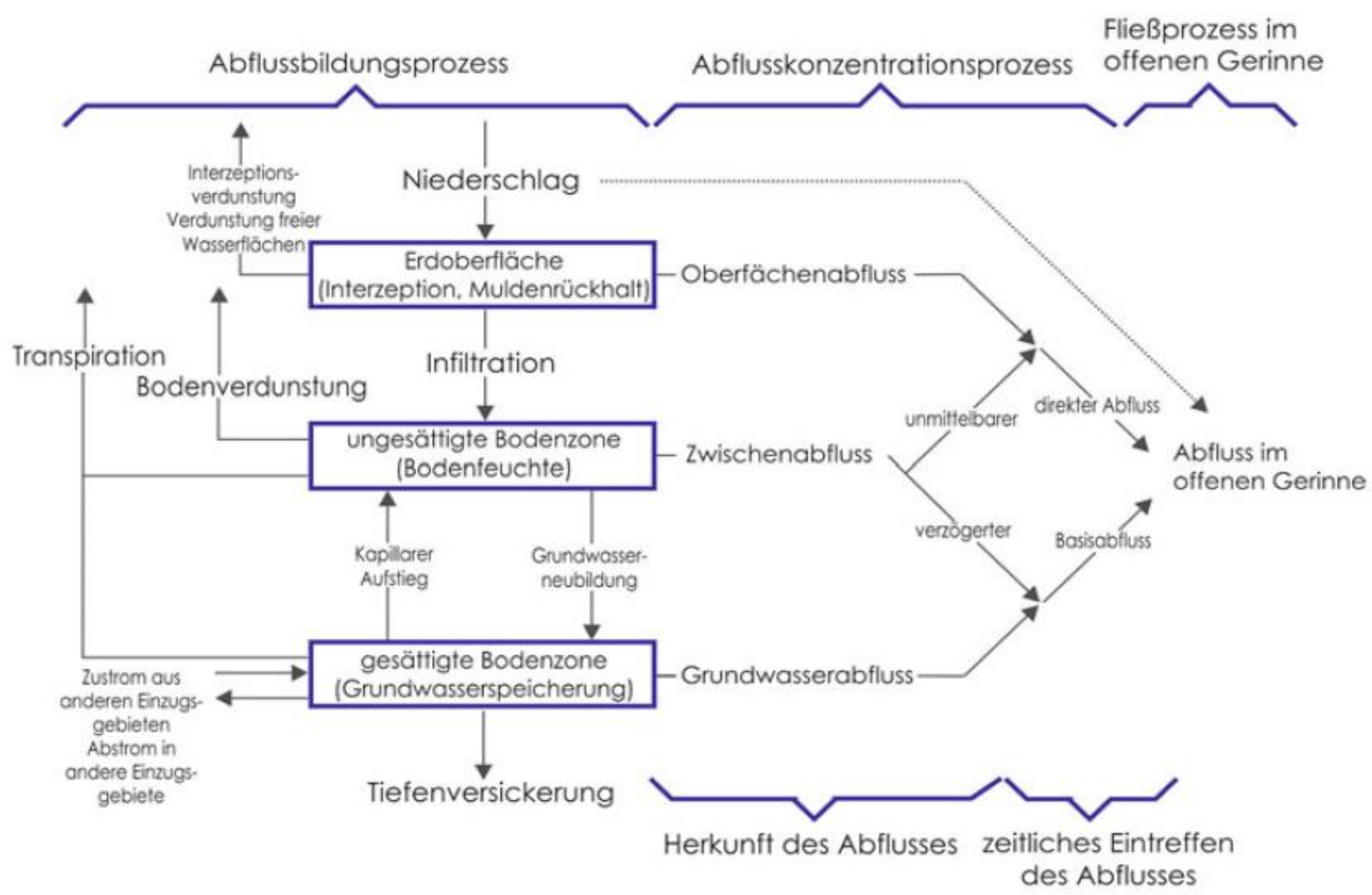

Abb. 5: Abflussprozesse bei der Hochwasserentstehung (Disse, 2013) 
Die von Hochwasserereignissen ausgehende Gefahr lässt sich durch Abflussstatistiken oder Niederschlag-Abfluss-Modelle und hydraulische Modellen zur Berechnung des Wasserstandes und der Überschwemmungsflächen quantifizieren. Im einfachsten Fall wird ein Bemessungsabfluss $\mathrm{HQ}_{\mathrm{T}}$ aus Statistiken für ein bestimmtes Wiederkehrintervall $\mathrm{T}$ ermittelt, dann der resultierende Wasserstand stationär berechnet und daraus werden die betroffenen Überschwemmungsflächen abgeleitet. Je höher der Abflussscheitel ist, desto tiefer sind der Wasserstand und größer die Überschwemmungsflächen und umso erheblicher sind die zu erwartenden Schäden (Niekamp und Piroth, 2013). Hochwasserschäden sind nach drei Kriterien direkt/indirekt, tangibel/intangibel, und primär/sekundär zu kategorisieren. Direkte Schäden entstehen durch die physische Einwirkung des Wassers, tangible Schäden lassen sich monetär beziffern, und primäre Schäden entstehen unmittelbar während des Hochwassers (Meyer, 2005).

Eine zukunftsweisende Hochwasserschutzstrategie umfasst dabei drei Handlungsbereiche: natürlicher Wasserrückhalt, technischer Hochwasserschutz und Hochwasservorsorge (Göttle, 2006; Jüpner, 2013; Brombach, 2013). Die Auen mit ihren Fließgewässern stellen als natürliche Retentionsräume nicht nur naturschutzfachlich wertvolle Gebiete dar, sondern sind für den natürlichen Wasserrückhalt von enormer Bedeutung. Das führt dazu, dass die Ökosystemleistung „Hochwasserschutz“ der Auen für den im allgemeinen Bewusstsein stärker wahrgenommen und durchaus anerkannt wird (Scholz et al., 2012; Brombach, 2013).

Bei der Diskussion über die Wirkung des Auenwaldes auf Hochwasser steht in der Regel sein Einfluss auf die Abflussbildung im Vordergrund. Konold (2006) behauptet, dass Wald ganz generell und pauschal puffernd auf die Abflussbildung wirkt, nicht nur wegen der Interzeption 
der Pflanzen und der guten Infiltration des Waldbodens, sondern auch durch die abflussverzögernde Oberflächenrauheit im Wald, die die Wurzeln, die Streudecke, der Bewuchs, die Ernterückstände und das liegen gebliebene Totholz bilden. Göttle (2006) und Hegg (2006) betonen, dass der Wald die Abflussbildung beeinflusst, nicht durch die Bäume, wie häufig vermutet, sondern durch die zusätzliche Speicherung von Wasser in gut strukturierten Waldböden. Verglichen mit Acker- oder Grünlandböden weisen Waldböden in der Regel eine größere Wasseraufnahmefähigkeit auf. Dies liegt daran, dass Waldböden meist eine höhere Infiltrations- und Speicherkapazität besitzen (organische Auflage, natürlich gelagerter Bodenaufbau, weniger Verdichtung), die Waldvegetation mehr Wasser verdunstet, und die tiefreichenden Wurzeln den Böden rascher und bis in größere Tiefen Wasser entziehen. Die Eigenschaften der Waldböden resultieren wiederum aus der Art und der Struktur des Waldes. Stufig aufgebaute Mischwälder weisen in der Regel aufgrund der hohen biologischen Aktivität einen günstigeren Humuszustand als Nadelholzbestände auf. Der Untergrund, auf dem sich ein Boden entwickelt, beeinflusst auch die Wirkung des Waldes auf die Speicherkapazität.

Schwaller und Tölle (2005) weisen am Beispiel der Glonn im Einzugsgebiet der Amper mit Hilfe der zweidimensionalen instationären hydrodynamisch-numerischen Abflussmodellierung quantitativ nach, dass eine großflächige Bewaldung im Vorland eine dämpfende und verzögernde Wirkungen auf den Hochwasserscheitel hat. Die Ergebnisse zeigen, dass Laufzeitverzögerungen bis zu 8,5 Stunden und Scheitelsenkungen bis zu ca. $9 \%$ erreicht werden können. Je höher der Waldanteil, umso größer fallen Verzögerung und Dämpfung des Scheitelabflusses aus. Die Retentionswirkung des Waldes wird durch eine Verminderung der Fließgeschwindigkeit erzielt, geht aber mit einer Erhöhung des 
Wasserstandes einher, die wiederum größere Überschwemmungsflächen bewirkt. Hellberg (2006) untersuchte ebenfalls den Einfluss der Wiederansiedlung von Gehölzen auf den Hochwasserabfluss im Einzugsgebiet der Weser unter Nutzung des eindimensionalen Wasserspiegellagenmodells. Mit einem kleinen Unterschied wird nachgewiesen, dass Erhöhungen des Wasserstandes und der Fließgeschwindigkeit durch dichten Auenwaldbewuchs zur Erhöhung der Retentionsvolumen führen, die wiederum den Spitzenabfluss um $0,5 \%$ bis 7,2 \% reduzieren können. Durch einen kombinierten Modellansatz aus dem physikalisch basierten Wasserhaushaltsmodell und dem zweidimensionalen hydrodynamisch-numerischen Modell bestätigt Rieger (2012) die Wirksamkeit des dichten Auenbewuchses für den Hochwasserschutz. Die Modellierungsergebnisse zeigen, dass die Auenwaldaufforstung beim $\mathrm{HQ}_{100}$-Ereignis das Scheitelsenkungspotential verfünffachen kann, und beim $\mathrm{HQ}_{50}$-Ereignis die Hochwasserspitzen um rund $10 \%$ reduzieren kann, beim $\mathrm{HQ}_{10}$-Ereignis jedoch eine geringe Wirkung hat.

Der klassische Ansatz für die ökonomische Bewertung der Hochwasserschutzmaßnahme erfolgt durch die Schadenspotenzialanalyse und die Methode des vermiedenen Schadens. Hochwasserschadenspotenziale ergeben sich aus der Hochwassergefahr und den möglicherweise auftretenden Schäden. Für die Ermittlung der Schadenspotenziale sind hydrologische und hydraulische Informationen wie Überflutungswahrscheinlichkeiten, Wasserstände in den Überschwemmungsflächen, die meistens durch Simulationen ermöglicht werden, sowie Informationen zu möglichen Schäden in Abhängigkeit von Wasserständen und Landnutzungen (sogenannte Wasserstand-Schadens-Funktionen) notwendig. Bei den Wasserstand-Schadens-Funktionen können zwei Ansätze unterschieden werden. In den 
absoluten Wasserstand-Schadens-Funktionen ergeben sich die monetären Schäden direkt aus dem Wasserstand, und bei den relativen werden zuerst Vermögenswerte auf den vom Hochwasser betroffenen Flächen abgeschätzt, dann werden die monetären Schäden in Bezug zu Vermögenswerten in Abhängigkeit vom Wasserstand berechnet (Meyer, 2005; Thieken et al., 2010; Niekamp und Piroth, 2013).

Die Masterarbeit von Barth (2014) ist die einzige Studie in Deutschland, die die Ökosystemleistung Hochwasserschutz eines Auenwalds monetär bewertet. Dabei wird der Beitrag des etwa 604 Hektar großen Auenwalds, der Bulau, im Einzugsgebiet der Kinzig in Hessen, zum Schutz der flussabwärts gelegenen Stadt Hanau untersucht. Zuerst werden die Retentionsvolumen der Bulau, sowohl oberirdisch als auch unterirdisch, und die Regulierung des Direktabflusses in der Bulau, bestehend aus Grundwasserneubildungsrate und Evapotranspiration, quantifiziert. Um die vermiedenen Schäden durch den Auenwald zu berechnen, wird das Abflussgeschehen eines bestimmten Hochwassers im Ist-Zustand mit Wirkung des Auenwalds und für ein alternatives Szenario ohne Auenwald modelliert. Die Differenz der beiden potenziellen Vermögensschäden drückt den Nutzen des Hochwasserschutzes aus. Dieser Betrag wird pro Jahr und in Bezug auf die Flächengrößen des Auenwalds angegeben. Aufgrund der begrenzten Datenverfügbarkeit wird in dieser Studie nur ein statistisches $\mathrm{HQ}_{10}$-Hochwasser ohne eine Modellierung, aber mit den bereits vorhandenen Daten aus den Hochwassergefahrenkarten betrachtet. Ferner werden nur die direkten tangiblen primären Hochwasserschäden für den schadensempfindlichen Landnutzungskategorien Siedlung, Industrie, Verkehr, Acker und Forst mithilfe von relativen Wasserstands-Schadens-Funktionen ermittelt. Aus diesem Verfahren ergibt sich das Ergebnis, dass der Auenwald bei einem 10-jährlichen Hochwasser potenziellen Vermögensschäden von 
mindestens 26 Mio. Euro, und zwar $4.279 € /$ ha/a, vermeidet. In diesem konkreten Fall liegen alle benötigen Daten vor. Allerdings sind Daten in diesem Detaillierungsgrad für die Flüsse in ganzen Niedersachsen nicht vorhanden, deshalb kann dasselbe Verfahren in der vorliegenden Arbeit nicht angewendet werden. Da der Vermögensschaden sehr stark in Abhängigkeit von Landnutzungstypen flussabwärts der Aue variiert, ist es kaum möglich, der Wert auf ein großes Untersuchungsgebiet zu übertragen.

Eine alternative Methode für die monetäre Bewertung des Hochwasserschutzes ist die Ersatzkostenmethode. Dabei werden die Kosten eines alternativen Verfahrens, zumeist einer technischen Lösungen, die dieselbe Leistung erbringt, ermittelt. Drei Voraussetzungen müssen für die Anwendung der Ersatzkostenmethode erfüllt werden: (1) Die betrachteten Alternativen entsprechen exakt der zu ersetzenden Leistung; (2) Die Variante wird bevorzugt, die die Leistungen zu den geringsten Kosten erbringt; (3) Es bestehen eindeutige Hinweise, dass die Leistung auch tatsächlich von der Gesellschaft nachgefragt wird (Grossmann et al., 2010). Im Fall des Hochwasserschutzes wären die technischen Lösungen z. B. Hochwasserrückhaltebecken, Deiche oder Dämme.

Barth (2014) führt auch eine Berechnung der Ersatzkosten durch. Aus den Kosten von geplanten Hochwasserrückhaltebecken im Einzugsgebiet der Kinzig und den Kosten der fertig gestellten Kinzigtalsperre sowie dem Retentionsvolumen jeder Anlage berechnen sich die mittleren Kosten in Höhe von $11,49 € / \mathrm{m}^{3}$. Die Ersatzkosten für die verschiedenen statistischen Hochwasser ergeben sich aus dem Produkt der jeweiligen oberirdischen Retentionsvolumen und der mittleren Kosten. Um die Ersatzkosten auf eine jährliche Basis und in Bezug auf die Größe des Auenwaldes in €/ha/Jahr umzurechnen, wird eine mittlere 
Nutzungsdauer der Anlagen von 60 Jahren angenommen. Im Rahmen dieser Arbeit wird von $1458 € /$ ha/Jahr bei $\mathrm{HQ}_{100}$ ausgegangen (Tab. 2).

Tab. 2: Ersatzkosten des Hochwasserschutzes des Auenwaldes in Bulau (Barth, 2014)

\begin{tabular}{|l|l|l|l|}
\hline Hochwasser & Retentionsvolumen $\left(\mathrm{m}^{3}\right)$ & Ersatzkosten $(€)$ & Ersatzkosten $(€ / \mathrm{ha} / \mathrm{Jahr})$ \\
\hline $\mathrm{HQ}_{10}$ & 2.674 .582 & 30.730 .947 & 848 \\
\hline $\mathrm{HQ}_{100}$ & 4.597 .853 & 52.829 .331 & 1.458 \\
\hline $\mathrm{HQ}_{\mathrm{ex}}$ & 5.928 .655 & 68.120 .246 & 1.880 \\
\hline
\end{tabular}

\subsection{Nutzen II: Nährstoffretention}

Die Retention von Nährstoffen in Auen ist eine der wichtigsten Ökosystemleitungen des Auenökosystems. Der Erhalt und die Renaturierung des Auenökosystems werden als wichtige Maßnahme zur Verbesserung der Wasserqualität von Flüssen anerkannt und können einen Beitrag zur Zielerreichung der WRRL leisten. Der tatsächliche Nährstoffrückhalt in Auen hängt von der Hydro-Geomorphologie der Auen sowie von der Nährstoffkonzentration selbst ab und wird durch verschiedene Prozesse reguliert: (1) Transport, (2) Transformation und Speicherung (Sedimentation, Adsorption, Aufnahme in Pflanzen), (3) Retention (Denitrifikation, Ernteentzug), (4) Remobilisierung (Erosion, Mineralisation, Desorption). Für den Stickstoffrückhalt gilt der Denitrifikationsprozess in Böden und die Aufnahme in Pflanzen als wichtigster Prozess, während die Prozesse der Sedimentation, neben der Bodenadsorption und der Pflanzenaufnahme für den Phosphorrückhalt entscheidend sind. Aus diesem Grund werden die Methoden zur Erfassung und Quantifizierung des Nährstoffrückhalts in Flussauen separat für Stickstoff und Phosphor dargestellt (SchulzZunkel et al., 2012).

Nach dem von Schulz-Zunkel et al. (2012) verwendeten Verfahren zur Abschätzung der Stickstoffretention wird ausschließlich der Denitrifikationsprozess der Böden berücksichtigt, 
bei dem nicht die Landnutzung, sondern die Bodentypen die Hauptrolle spielt. Das bedeutet, dass der Landnutzungsänderung keine Änderung der Retentionsleistung zukommt, was in unserem Projekt nicht geeignet ist. Deswegen werden hier die aus dokumentierten Fallstudien abgeleiteten Faustzahlen angesetzt.

Bei der Landnutzung „Ackerland“ wird die von Schmidt et al. (2007) entwickelte Methode zur Berechnung der Stickstoffbilanz, die als das Maß für die landwirtschaftliche N-Emission dient, herangezogen. Diese Berechnung beschränkt sich auf die Stoffflüsse innerhalb des Agrarsektors und berücksichtigt nicht den Einfluss der Deposition (die nachher noch hinzugefügt wird) und der Denitrifikation (die wie erwähnt nur von den Bodentypen abhängt). Ermittelt wird die N-Bilanz durch:

$\mathrm{N}$-Bilanz $=$ Wirtschaftsdüngereinsatz (tierische N-Ausscheidungen) abzüglich Ammoniakverluste

+/- die Summe des im- und exportierten Wirtschaftsdünger abzüglich Ammoniakverluste

+ Sekundärrohstoffdünger

+ Mineraldünger

+ legume N-Bindung abzüglich Ammoniakverluste

- Abfuhr von Marktfruchtprodukten und Grundfutter

Für die Berechnung der tierischen Stickstoffausscheidungen werden die von der Landwirtschaftskammer vorgelegten Koeffizienten verwendet. Die N-Ausscheidungen pro Tier bzw. Stallplatz und Jahr hängen von dem Alter der Tiere und der Rasse sowie der Haltungs- und Fütterungsart ab (Schmidt et al., 2007). Ammoniak $\left(\mathrm{NH}_{3}\right)$ - Verluste entstehen im Stallbereich, bei der Lagerung oder bei der Ausbringung auf dem Feld. Weidetiere 
emittieren zusätzlich Ammoniak während des Weidegangs. Die Höhe der Ammoniakverluste ist abhängig von der Tierart, dem Fütterungs- und Stallhaltungssystem und der Lager- und Ausbringtechnik (Schmidt et al., 2007; Wienhaus, 2008).

Wenn das Aufkommen an Wirtschaftsdünger in einer Gemeinde die zulässige Höchstmenge nach Düngeverordnung (170 kg N pro ha beim Ackerland, $210 \mathrm{~kg} \mathrm{~N}$ pro ha beim Grünland) überschreitet, wird der Überschuss an Wirtschaftsdünger exportiert und auf jene Gemeinden verteilt, die nicht zwingend exportieren müssen und in denen importierende Betriebe gemeldet sind. Die Ammoniakverluste werden davon auch abgezogen werden. Ein Mittelwert aller Ausbringungstechniken ist der Studie von Schmidt et al. (2007) zu entnehmen.

Die Sekundärrohstoffdünger umfassen Klärschlamm, Kompost und grenzüberschreitende organische Düngermittel. Bezogen auf die Ackerfläche Niedersachsens entspricht die landwirtschaftliche Klärschlammverwertung einer durchschnittlichen Menge von ca. $5 \mathrm{~kg} \mathrm{~N}$ pro ha und Jahr, und die Kompostverwertung ca. $2 \mathrm{~kg} \mathrm{~N}$ pro ha und Jahr. Bei den grenzüberschreitenden Düngermitteln spielt nur der Import von Hühnertrockenkot aus den Niederlanden eine Rolle. Dessen Bedeutung dürfte im grenznahen Bereich zu den Niederlanden besonders hoch liegen, aber die regionale Verteilung konnte nicht berücksichtigt werden, weil hierzu keine Datenauswertungen zur Verfügung stehen (Schmidt et al., 2007).

Für die einzelbetrieblichen und regionalen N-Mineraldüngereinsatzmengen liegen keine statistischen Daten vor. Deshalb wird ein Modell in Abhängigkeit von der N-Abfuhr und des Wirtschaftsdüngeranfalls aus Betriebsdaten abgeleitet und auf die Ackerfläche Niedersachsens angewendet (Schmidt et al., 2007). Die Ammoniakverluste davon waren, laut 
dem nationalen Inventarreport für das Jahr 2003, mit 5,5\% des Mineraldüngereinsatzes ausgewiesen, aber in der Studie von Schmidt et al. (2007) ist diese Größe nicht berücksichtigt. Dieses geschieht hingegen in der vorliegenden Arbeit.

Eine pauschale Mengenangabe für die legume $\mathrm{N}$-Bindung (symbiontische $\mathrm{N}_{2}$-Fixierung) für die Anbauflächen von Futtererbsen, Ackerbohnen und sonstige Hülsenfrüchte wird aus der Musterverwaltungsvorschrift entnommen (Schmidt et al., 2007). Laut Annahme der European Environment Agency beträgt der Ammoniakverlust 1\% der legumen N-Bindung.

Bei der Ermittlung der N-Abfuhr wird zwischen Marktfruchtprodukten und Grundfutter unterschieden. Die Abfuhrmenge der Marktfrüchte berechnet sich aus der Summe aller Entzüge über die geerntete Biomasse (Erträge und Flächengröße), multipliziert mit dem jeweiligen Nährstoffgehalt. Im Unterschied zu den Marktfrüchten wird die N-Abfuhr von Grundfutter durch ein Modell geschätzt, das die Bedarfswerte auf Gemeindeebene in Abhängigkeit von der gegebenen Agrarstruktur (Tierzahlen, Leistung und Kraftfuttereinsatz) und aus Buchführungsdaten abgeleiteten Koeffizienten errechnet (Schmidt et al., 2007). Tab. 3 gibt einen Überblick über alle N-Bilanzglieder und weist die absoluten Werte (Aggregat aus Gemeindebilanzen) für Niedersachsen aus.

Tab. 3: N-Bilanz für Niedersachsen (modifiziert nach Schmidt et al., 2007)

\begin{tabular}{|l|l|l|l|l|l|l|}
\hline \multicolumn{2}{|l|}{ Gegenstand } & & \multicolumn{2}{l}{1999} & \multicolumn{2}{l|}{2003} \\
\cline { 3 - 7 } & & $\mathrm{t}$ & $\mathrm{kg} / \mathrm{ha}$ & $\mathrm{t}$ & $\mathrm{kg} / \mathrm{ha}$ \\
\hline 1 & tierische Ausscheidungen & + & 267.704 & 107 & 265.435 & 107 \\
\hline 1.1 & $\begin{array}{l}\text { davon Ammoniak-Verluste aus Stall, } \\
\text { Weide und Lagerung }\end{array}$ & - & 48.422 & 19 & 49.117 & 20 \\
\hline 1.2 & $\begin{array}{l}\text { davon Ammoniak-Ausbringungsverluste } \\
\text { aus eigenem Wirtschaftsdünger }\end{array}$ & - & 24.763 & 10 & 24.504 & 10 \\
\hline 2 & Im- und Exportierte Wirtschaftsdünger & & 5.34 & 2 & 6.252 & 3 \\
\hline 2.1 & davon Ammoniak-Ausbringungsverluste & - & 274 & 0 & 392 & 0 \\
\hline 3 & Sekundärrohstoffdünger & & & & & \\
\hline
\end{tabular}




\begin{tabular}{|l|l|l|l|l|l|l|}
\hline 3.1 & Klärschlamm & + & 8.536 & 3 & 8.3 & 3 \\
\hline 3.2 & Kompost & + & 1.91 & 1 & 1.963 & 1 \\
\hline 3.3 & Grenzüberschreitende Abfallverbringung & + & 248 & 0 & 310 & 0 \\
\hline 4 & Mineraldünger & + & 329.275 & 131 & 317.726 & 128 \\
\hline 5 & legume N-Bindung & + & 27.068 & 11 & 25.468 & 10 \\
\hline 5.1 & davon Ammoniakverluste & - & 271 & 0 & 255 & 0 \\
\hline 6 & Abfuhr insgesamt & - & 325.55 & 130 & 304.795 & 123 \\
\hline 6.1 & Abfuhr Marktfrüchte & & 171.831 & 125 & 157.654 & 112 \\
\hline 6.2 & Abfuhr Raufutter & & 153.719 & 138 & 147.141 & 139 \\
\hline & Saldo & $=$ & 235.461 & 94 & 240.139 & 96 \\
\hline
\end{tabular}

Die N-Bilanzen für Niedersachsen in den Jahren 1999 und 2003 fallen positiv aus, was eine N-Emission vom Ackerland bedeutet. Die N-Salden sind in den beiden Vergleichsjahren etwa gleich hoch. In dieser Arbeit wird von 96 kg/ha/a N-Emission des Agrarsektors ausgegangen. Darüber hinaus werden noch $15 \mathrm{~kg}$ N/ha/a als eine Größe der N-Zufuhr durch atmosphärische Stickstoffdeposition mit einbezogen (Wienhaus, 2008). Infolgedessen beträgt die N-Emission beim Ackerland $111 \mathrm{~kg} / \mathrm{ha} / \mathrm{a}$.

Bei der Landnutzung „Wald“ ist die Hauptquelle der Stickstoffeinträge die Deposition von atmosphärischem Stickstoff, welcher die Stickstoffaufnahme durch den Waldbestand gegenüberzustellen ist. Nach einem vereinfachten Ansatz ist die N-Emission bei Forstflächen pauschal mit einem Netto-Betrag von $30 \mathrm{~kg} / \mathrm{ha} / \mathrm{a}$ anzusetzen (Wienhaus, 2008). Bei der Landnutzung „Grünland“ kann wegen dem Fehlen geeigneter Studien nur angenommen werden, dass der Netto-Betrag von N-Emissionen beim Grünland gleich dem des Walds ist.

Für die Abschätzung der Phosphorretention wird das von Scholz et al. (2012) verwendete Verfahren verfolgt. Für jede der sieben Landnutzungsklassen des Digitalen Landschaftsmodells wird ein Strickler-Beiwert $\left(\mathrm{k}_{\mathrm{st}}\right)$ berechnet, der weiter in Rauheitsklassen (1 = sehr hohe Rauheit bis $5=$ sehr geringe Rauheit $)$ überführt wird und dem 
Phosphorretentionsraten (Stufe 1 bis Stufe 5) zugeordnet werden. Der Strickler-Beiwert spiegelt den Effekt der Boden bedeckenden Vegetation auf das Retentionsverhalten wider. Die Vegetation agiert als Filter für transportiertes gelöstes Material. Ihre Filterfunktion steigt mit dem Anstieg der Oberflächenrauheit und der sich daraus ableitenden Abnahme der Fließgeschwindigkeit und des Wasservolumens (Scholz et al., 2012).

Die potenziellen Phosphorretentionsraten für die verschiedenen Rauheitswerte lassen sich aus veröffentlichten Fallbeispielen ermitteln (Tab. 4). Bei der Festlegung der Faustzahlen für die P-Retention wird der als konservativ einzuschätzende Wert von $1 \mathrm{~kg} P$ pro ha und Jahr als "Ankerpunkt" für eine mittlere Rauheit angenommen. Ausgehend vom Ankerwert $1 \mathrm{~kg}$ P pro ha und Jahr (Stufe 3 der potenziellen P-Retentionsrate) erfolgt die weitere Zuordnung der Stufen 1 und 2 in Schritten von $+1,5$ bzw. $+2,5$ und die Zuordnung der Stufen 4 und 5 in Schritten von jeweils -0,25. Hier werden eher konservative Annahmen für die Festlegung der P-Retention für die Stufen 1 und 2 getroffen, um diesen Effekt in Auen nicht zu überschätzen (Scholz et al., 2012).

Tab. 4: Rauheitsklassen und Phosphorretentionsraten für sieben Landnutzungskategorien (eigene Darstellung nach Scholz et al., 2012)

\begin{tabular}{|l|l|l|l|}
\hline Landnutzungskategorien & $\mathrm{k}_{\mathrm{st}}$ & Rauheitsklassen & $\begin{array}{l}\text { Potenzielle P- } \\
\text { Retentionsraten }\end{array}$ \\
\hline Wald & 7 & 1 (sehr hohe Rauheit) & Stufe $1: 5 \mathrm{~kg} / \mathrm{ha} / \mathrm{a}$ \\
\hline Feuchtgebiet & 11 & 2 (hohe Rauheit) & Stufe $2: 2,5 \mathrm{~kg} / \mathrm{ha} / \mathrm{a}$ \\
\hline Ackerland & 15 & 3 (mittlere Rauheit) & Stufe $3: 1 \mathrm{~kg} / \mathrm{ha} / \mathrm{a}$ \\
\hline Grünland & 20 & 4 (geringe Rauheit) & Stufe $4: 0,75 \mathrm{~kg} / \mathrm{ha} / \mathrm{a}$ \\
\hline Siedlung & 20 & 4 (geringe Rauheit) & Stufe $4: 0,75 \mathrm{~kg} / \mathrm{ha} / \mathrm{a}$ \\
\hline Gewässer & 40 & 5 (sehr geringe Rauheit) & Stufe $5: 0,5 \mathrm{~kg} / \mathrm{ha} / \mathrm{a}$ \\
\hline Vegetationslos & 50 & 5 (sehr geringe Rauheit) & Stufe $5: 0,5 \mathrm{~kg} / \mathrm{ha} / \mathrm{a}$ \\
\hline
\end{tabular}

Bei der ökonomischen Bewertung der Nährstoffretention wird in der Regel auch die Ersatzkostenmethode herangezogen. Bei der Wahl eines geeigneten Substituts für die Ökosystemleistung Nährstoffretention wird darauf geachtet, diese auf die Prozessanalogie, 
wie sie in der Aue stattfindet und auf die Art des Eintrags (diffus oder punktuell) zu prüfen. Meistens wird dafür mit Szenarien gearbeitet, die technische und politische Alternativen beinhalten. Hierzu werden drei Szenarien „Kläranlage“, „landwirtschaftliche Strategien“ und „Trinkwasseraufbereitung“ examiniert. Das Szenarium „Kläranlage“ bezieht sich auf einmalig anfallende Investitions- und fortlaufende Betriebskosten für die Klärverfahren zur Abwasserreinigung mit Punktquellcharakter. Bei dem Szenarium „landwirtschaftliche Strategien“ handelt es um die Maßnahmen zur Verminderung diffuser Nährstoffeinträge aus der landwirtschaftlichen Produktion. Im Vergleich mit der Abwasserreinigung (Kläranlage) bedarf das Szenarium „Trinkwasseraufbereitung“ zusätzlicher Reinigungsstufen und entspricht einem höheren Qualitätsniveau (Scholz et al., 2012). Tab. 5 fasst diese Szenarien entsprechend ihrer Prozessanalogie und der Art der Eintragsquelle (Quellenkonformität) zusammen. Die Zeichen + und - verdeutlichen jeweils die gute oder schlechte Eignung des Szenariums hinsichtlich des Kriteriums.

Tab. 5: Alternative Szenarien zur Nährstoffreduktion (modifiziert nach Scholz et al., 2012)

\begin{tabular}{|l|l|l|l|}
\hline \multirow{2}{*}{ Kriterium } & \multicolumn{3}{|c|}{ Szenarien } \\
\cline { 2 - 4 } & Kläranlage & $\begin{array}{l}\text { Landwirtschaftliche } \\
\text { Strategien }\end{array}$ & Trinkwasseraufbereitung \\
\hline Prozessanalogie & + & - & + \\
\hline Quellenkonformität & punktuell - & diffus + & punktuell und diffus + \\
\hline
\end{tabular}

Ausgehend von verschiedenen Literaturquellen werden in Tab. 6 die Werte der Grenzvermeidungskosten, die als Ersatzkosten verwendet werden, für diese Szenarien angesetzt. Aus zwei Gründen werden die Werte aus dem Szenarium „landwirtschaftliche Strategien “ $(6 € / \mathrm{kg} \mathrm{N}$ und $60 € / \mathrm{kg} \quad \mathrm{P})$ endgültig gewählt. Erstens, weil die Ersatzkostenmethode entsprechend der zweiten Voraussetzung die geringsten Grenzkosten verwendet, daher wird das Szenarium „Trinkwasseraufbereitung“ vernachlässigt. Zweitens, 
$60 \%$ der Nährstoffeinträge haben diffusen Charakter und landwirtschaftliche Strategien wie geringerer Düngemitteleinsatz beeinflussen diese Art des Eintrags (Scholz et al., 2012).

Tab. 6: Ersatzkosten für die Szenarien zur Nährstoffreduktion (Scholz et al., 2012)

\begin{tabular}{|c|c|c|c|}
\hline & \multicolumn{3}{|l|}{ Maßnahme } \\
\hline & Kläranlage & $\begin{array}{l}\text { Landwirtschaftliche } \\
\text { Strategien }\end{array}$ & Trinkwasseraufbereitung \\
\hline \multirow[t]{3}{*}{$\begin{array}{l}\text { Grenzvermeidungskosten } \\
\mathrm{N}(€ / \mathrm{kg})\end{array}$} & $\begin{array}{l}3,9-35,1 \\
(\text { Gren } \\
1995)^{*}\end{array}$ & $\begin{array}{l}0-43,0 \\
(\text { Gren } 2008) *\end{array}$ & $\begin{array}{l}56,2 \\
\text { (Bütow und Homann } \\
1992) *\end{array}$ \\
\hline & $\begin{array}{l}5,0-62,0 \\
(\text { Siewert } \\
2010) *\end{array}$ & $\begin{array}{l}6,0 \\
(\text { Mies 2006) } *\end{array}$ & \\
\hline & & $\begin{array}{l}7,2-10,8 \\
(\text { Helin et al. 2006) * }\end{array}$ & \\
\hline $\begin{array}{l}\text { Grenzvermeidungskosten } \\
\mathrm{P}(€ / \mathrm{kg})\end{array}$ & $\begin{array}{l}6,6-80,0 \\
\text { (Siewert } \\
2010) *\end{array}$ & $\begin{array}{l}60,0-95,0 \\
(\text { Mies 2006) } *\end{array}$ & \\
\hline
\end{tabular}

*Alle Daten sind aus Scholz et al. (2012) zitiert.

Abschließend werden die oben ermittelten Retentionspotenziale mit den Grenzkosten multipliziert. Das Produkt hieraus ist der monetäre Nutzen der Nährstoffretentionsleistung Zusammenfassend lassen sich die Ergebnisse des Nutzens von Nährstoffretention durch die Landnutzungsänderung in Tab. 7 darstellen.

Tab. 7: Nutzen der Nährstoffretention durch die Landnutzungsänderung (eigene Darstellung)

\begin{tabular}{|c|c|c|c|c|c|c|c|}
\hline \multirow[t]{2}{*}{$\begin{array}{l}\text { Landnutzungsä } \\
\text { nderung }\end{array}$} & \multirow{2}{*}{$\begin{array}{l}\text { N-Emissions- } \\
\text { senkung } \\
(\mathrm{kg} / \mathrm{ha} / \mathrm{a})\end{array}$} & \multirow{2}{*}{$\begin{array}{l}\text { P-Retentions- } \\
\text { erhöhung } \\
\text { (kg/ha/a) }\end{array}$} & \multicolumn{2}{|c|}{$\begin{array}{l}\text { Ersatzkosten } \\
(€ / \mathrm{kg})\end{array}$} & \multicolumn{3}{|c|}{ Nutzen $(€ / \mathrm{ha} / \mathrm{a})$} \\
\hline & & & $\mathrm{N}$ & $\mathrm{P}$ & $\mathrm{N}$ & $\mathrm{P}$ & Summe \\
\hline $\begin{array}{l}\text { Ackerland zu } \\
\text { Wald }\end{array}$ & 81 & 4 & 6 & 60 & 486 & 240 & 726 \\
\hline $\begin{array}{l}\text { Grünland zu } \\
\text { Wald }\end{array}$ & 0 & 4.25 & & & 0 & 255 & 255 \\
\hline
\end{tabular}

\subsection{Nutzen III: Kohlenstoffspeicherung}

Flussauen werden in ihrer doppelten Funktion als Kohlenstoffquellen und -senken noch nicht genügend verstanden. Sie besitzen dann eine Senkenfunktion, wenn mehr Kohlenstoff über einen bestimmten Zeitraum akkumuliert als durch andere Umsetzungsprozesse freigesetzt 
wird. Ist die freigesetzte Kohlenstoffmenge größer, spielen Auen die Rolle der Kohlenstoffquelle. Jedoch weisen unterschiedliche Untersuchungen darauf hin, dass die in Auen sowohl in Böden als auch in der Vegetation gespeicherten Kohlenstoffvorräte deutlich höher liegen als in terrestrischen Ökosystemen (Scholz et al., 2012).

Die Kohlenstoffvorratsänderungen in Mineralböden aufgrund der Landnutzungsänderung werden als Differenz des Kohlenstoffvorrates der Zielnutzungskategorie und des Kohlenstoffvorrates der Ursprungskategorie berechnet. Die Gesamtänderung wird auf einen Zeitraum von 20 Jahren linear verteilt. Durch die Umwandlung von Ackerland in Wald werden 0,10 t $\mathrm{C}$ pro ha und pro Jahr in Böden gespeichert, aber 0,77 t C pro ha und Jahr emittieren infolge der Landnutzungsänderung von Grünland zu Wald. Die Abschätzung der Kohlenstoffvorratsänderungen in der ober- und unterirdischen Biomasse erfolgt durch Subtraktion des Biomassekohlenstoffvorrats vor der Nutzungsänderung vom Vorrat nach der Nutzungsänderung. Es werden jeweils 3,8 t C pro ha pro Jahr in der Biomasse durch die Umwandlung von Acker- bzw. Grünland in Wald eingebunden (UBA, 2012c). Die Kohlenstoffvorratsänderung wird für die Umrechnung in $\mathrm{CO}_{2}$ mit dem Faktor von 3,67 multipliziert, der sich aus dem Verhältnis der Molekülmasse von $\mathrm{CO}_{2} \mathrm{zu}$ dem von $\mathrm{C}$ ergibt.

Bei der ökonomischen Bewertung der Kohlenstoffspeicherung stehen zwei Ansätze zur Verfügung. Zum einen basieren die Schätzungen auf dem Marktpreis des Emissionsrechts, der tagesaktuell von der Europäischen Energie-Börse in Leipzig zu entnehmen ist. Der Marktpreis spiegelt zwar genau den Wert wider, den ein Marktteilnehmer zu zahlen bereit ist, um eine Tonne $\mathrm{CO}_{2}$ auszustoßen zu dürfen, aber er unterliegt aus politischen Gründen starken Schwankungen. Zum Beispiel beschlossen die EU-Staaten im Januar 2014 die Verknappung 
von $\mathrm{CO}_{2}$-Zertifikaten, um den Markt zu stabilisieren, was zu den am Jahresanfang beobachteten starken Preisschwankungen führt (EEX, 2014). Zum anderen werden Schadenskosten herangezogen. Bei der Schadenskostenmethode wird zunächst die Wirkungskette von der Umwelteinwirkung über den Transport und möglicherweise auftretende chemische Umwandlungsprozesse bis hin zur Wirkung auf verschiedene Rezeptoren erfasst und die so quantifizierten physischen Schäden werden monetär bewertet (UBA, 2012a).

Der Marktpreis für Emissionszertifikate beträgt 6,93 €/ t CO $\mathrm{CO}_{2}$ zum Jahresende 2014 (EEX, 2014), während das UBA (2012b) empfiehlt, den Wert $80 € / t \mathrm{CO}_{2}$ als Schadenskosten zu verwenden. Die große Abweichung der Schadenskosten vom Marktpreis ergibt sich durch die externen Umweltkosten, die beim Marktpreis gänzlich vernachlässigt werden. Wüstemann et al. (2014) verwenden die Schadenskosten für die Berechnung des Nutzens der Vermeidung der Treibhausgasemissionen in einer deutschlandweiten Kosten-Nutzen-Studie. Deshalb wird im Rahmen dieser Arbeit auch auf die Schadenskosten zurückgegriffen, wobei der Nutzen von der Kohlenstoffspeicherung für die Umwandlung von Ackerland und Grünland zu Wald jeweils 1.145 und $890 € /$ ha/a beträgt (Tab. 8).

Tab. 8: Nutzen der $\mathrm{CO}_{2}$-Speicherung durch Landnutzungsänderung (eigene Darstellung)

\begin{tabular}{|c|c|c|c|c|c|}
\hline \multirow{2}{*}{$\begin{array}{l}\text { Landnutzungs- } \\
\text { änderung }\end{array}$} & \multicolumn{3}{|c|}{ Kohlenstoffvorratsänderung (t/ha/a) } & \multirow{2}{*}{$\begin{array}{l}\text { Schadens- } \\
\text { kosten } \\
(€ / \mathrm{t})\end{array}$} & \multirow{2}{*}{$\begin{array}{l}\text { Nutzen der } \mathrm{CO}_{2-} \\
\text { Speicherung } \\
(€ / \text { ha/a) }\end{array}$} \\
\hline & Böden & Biomasse & Gesamt & & \\
\hline $\begin{array}{l}\text { Ackerland zu } \\
\text { Wald }\end{array}$ & $0,10 \mathrm{C}$ & $3,8 \mathrm{C}$ & $\begin{array}{l}3,9 \mathrm{C}(14,31 \\
\left.\mathrm{CO}_{2}\right)\end{array}$ & \multirow[t]{2}{*}{80} & 1145 \\
\hline $\begin{array}{l}\text { Grünland zu } \\
\text { Wald }\end{array}$ & $-0,77 \mathrm{C}$ & $3,8 \mathrm{C}$ & $\begin{array}{l}3,03 \mathrm{C}(11,12 \\
\left.\mathrm{CO}_{2}\right)\end{array}$ & & 890 \\
\hline
\end{tabular}




\subsection{Nutzen IV: Biodiversität}

Es besteht Einigkeit in der Literatur, dass Auenwälder nicht nur die ursprüngliche Vegetation der Flussauen sind, sondern auch zu den artenreichsten Ökosystemen Mitteleuropas gehören. Grundlage dieser biologischen Vielfalt sind die Hydrodynamik zwischen hohen und niedrigen Abflüssen, die geomorphologisch verändernde Kraft des fließenden Wassers, die überflutungsbedingte Nährstoffverfügbarkeit und Wasserversorgung für das Pflanzenwachstum, sowie eine gute Nahrungsmöglichkeit für die Tierwelt. Auf engstem Raum werden kleinräumig wechselnde Standortbedingungen geschaffen, an die sich Pflanzen- und Tierarten mit speziellen Strategien anpassen müssen, um überleben zu können (Scholz et al., 2012).

Im Rahmen der nationalen Strategie zur biologischen Vielfalt (BMU, 2007) wird eine bundesweite Kontingente-Bewertungsstudie für die Biodiversitätsschutzprogramme durchgeführt. Dabei werden sechs verschiedene Ökosysteme berücksichtigt, unter anderem sind ca. 500.000 ha Flussauen. Maßnahmen für den Biodiversitätsschutz der Flussauen umfassen Konservierung und Neuetablierung der artenreichen Feuchtwiesen und Auenwälder, naturnahe Entwicklung der bestehenden Auenwälder, jährliches Mähen und Verzicht auf Düngung der Feuchtwiesen, Wiederherstellung der Überschwemmungsdynamik, sowie Umwandlung von Ackerland in angepasste Nutzungen. Die Ergebnisse einer InternetBefragung ergaben, dass die aggregierte jährliche Zahlungsbereitschaft der deutschen Haushalte für die Schutzmaßnahme der Flussauen 1,18 Milliarden Euro beträgt. Umgerechnet auf die betrachtete Fläche von 500.000 ha ergibt sich ein Betrag von $2.360 € / \mathrm{ha} / \mathrm{Jahr}$ (Meyerhoff et al., 2012). Von diesem Wert wird in der vorliegenden Arbeit für den Nutzen der Biodiversität ausgehen. 


\subsection{Ergebnisse}

Die Ergebnisse bestehen aus einer „shape“-Datei, die die räumliche Lage aller potentiellen Flächen darstellt, und einer Tabelle, die als Datenbank alle Attribute jeder Fläche zeigt. Insgesamt befinden sich 61.231 Flächen, die durch das Landbedeckungsmodell bestimmt werden, in den vom BfN definierten Flussauengebieten Niedersachsens, von denen 27.882 Flächen Ackerland und Grünland sind. Mit Hilfe des Werkzeugs „spatial join“ vom ArcGISProgramm lassen sich die Landnutzungen mit allen oben genannten ökologischen Faktoren verbinden. Durch die notwendigen Faktoren werden 2.455 Flächen ausgewählt, darunter 1.805 Flächen mit positiven Nettonutzen (Abb. 11). $20 \%$ der ausgewählten Flächen sind in Region Hannover zu finden, Heidekreis, Lüneburg, Emsland und Hildesheim haben jeweils über $10 \%$ der Flächen (Tab. 9). Werden alle Faktoren mit einbezogen, beträgt die Flächenanzahl 372.

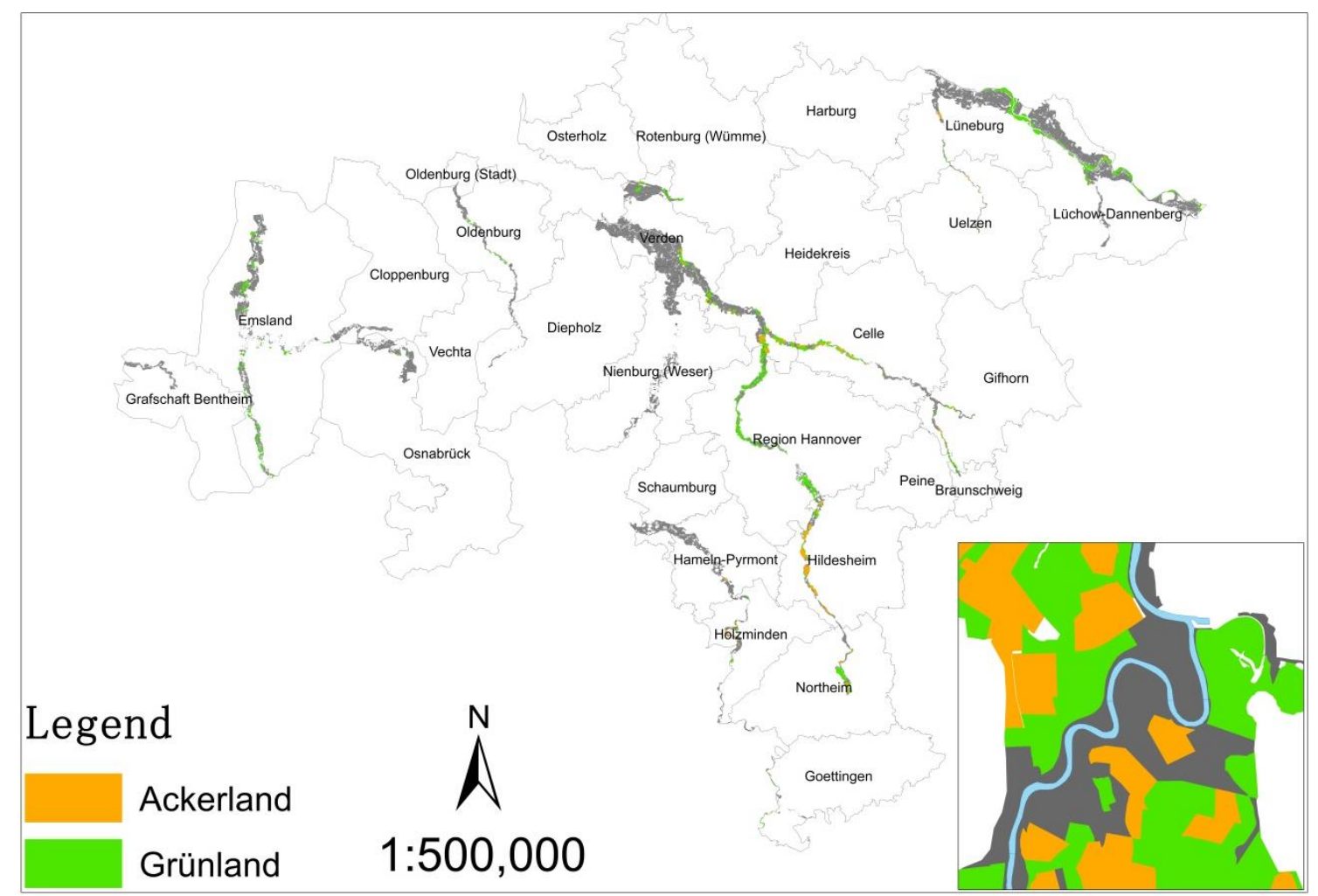

Abb. 11: Karte der ausgewählten Flächen 
Tab. 9: Verteilung der ausgewählten Flächen in Landkreisen

\begin{tabular}{|l|l|l|}
\hline Landkreis & Anzahl & Prozent \\
\hline Celle & 153 & $8.48 \%$ \\
\hline Emsland & 204 & $11.30 \%$ \\
\hline Gifhorn & 47 & $2.60 \%$ \\
\hline Göttingen & 12 & $0.66 \%$ \\
\hline Hameln-Pyrmont & 1 & $0.06 \%$ \\
\hline Heidekreis & 255 & $14.13 \%$ \\
\hline Hildesheim & 185 & $10.25 \%$ \\
\hline Holzminden & 34 & $1.88 \%$ \\
\hline Lüchow-Dannenberg & 85 & $4.71 \%$ \\
\hline Lüneburg & 232 & $12.85 \%$ \\
\hline Northeim & 83 & $4.60 \%$ \\
\hline Oldenburg & 26 & $1.44 \%$ \\
\hline Osterholz & 1 & $0.06 \%$ \\
\hline Peine & 2 & $0.11 \%$ \\
\hline Region Hannover & 361 & $20.00 \%$ \\
\hline Rotenburg (Wümme) & 20 & $1.11 \%$ \\
\hline Uelzen & 10 & $0.55 \%$ \\
\hline Verden & 94 & $5.21 \%$ \\
\hline Summe & 1805 & $100.00 \%$ \\
\hline
\end{tabular}

Beispielhaft wird hier eine Fläche ausgewählt und die Information dafür dargestellt (Abb. 12). Diese Fläche in Lüneburg wird als Grünland genutzt und befindet sich in der rezenten Aue mit der Zustandsklasse 3. Sie ist 2,46 ha groß und in dem Prioritätsbereich des niedersächsischen Auenprogramms. Bei einem $\mathrm{HQ}_{100}$-Hochwasser wird die Fläche mit einer Wassertiefe von 1 bis 2 Meter überflutet. Der Habitatindex ist 2. Der Kaufpreis dieser Fläche beträgt 37.849,56 $€$ und die Anpflanzungskosten für den Auenwald sind 492,00 €. Die Landnutzungsänderung von Ackerland zu Wald erbringen Nutzen für Hochwasserschutz, Nährstoffretention, Kohlenstoffspeicherung und Biodiversität in Höhe von 3.586,68€, $627,30 €, 2189,40 €$ und 5.805,60 € pro Jahr. Hierdurch ergibt sich bei einer Projektlaufzeit von 20 Jahren ein diskontierter Nettonutzen von 39.152,16€. Ausgehend von einer Beihilfe von $50.000 €$ errechnet sich eine ökonomische Effizienz der Auenwaldetablierung von 0,78. 


\begin{tabular}{|c|c|}
\hline Field & Value \\
\hline Landkreis & Lineburg \\
\hline Landnutrung & Griinland \\
\hline Teil & Rezkue \\
\hline Zustand & 3 \\
\hline Grösse & 2.46 \\
\hline Priorität & $\mathrm{Ja}$ \\
\hline Wlassertiefe & $>1-2 m$ \\
\hline Habitatindex & 2 \\
\hline Kosten_I & 37849.56 \\
\hline Kosten_II & 492 \\
\hline Hutzen_I & 3586.68 \\
\hline Hutzen_II & 627.3 \\
\hline Hutzen_III & 2189.4 \\
\hline Hutzen_IV & 5805.6 \\
\hline Hettonutzen & 39152.16 \\
\hline Effizienz & .78 \\
\hline
\end{tabular}

Abb. 12: Information einer einzelnen Fläche

\section{Schlussfolgerung}

Viele Auenflächen sind in Deutschland durch eine Abtrennung vom Gewässer verloren gegangen. Von den verbliebenen rezenten Auen befindet sich ein Großteil nicht in dem naturnahen Zustand, der mit zahlreichen ökosystemaren Funktionen und Leistungen einhergeht (Brunotte et al. 2009; Scholz et al. 2012). Diese Arbeit fokussiert darauf, mögliche kosteneffiziente Alternativen (geeignete Flächen für die Auenwaldetablierung) unter dem politischen Ziel der Renaturierung der Flussauen auszuwählen. Hierfür wird die traditionelle Kosten-Nutzen Analyse dadurch ergänzt, dass der monetäre Nettonutzen und ökologische Faktoren in die Auswahl einbezogen werden. Hierdurch kann eine gezielte Auswahl von Flächen für die Renaturierung erfolgen, z. B. nur von Flächen, die bisher als Ackerland genutzt werden, um eventuelle Zielkonflikte zwischen dem Erhalt von Feuchtgrünland und der Etablierung von Auenwald zu vermeiden.

Die Bewertung der Ökosystemleistungen der Auenwälder besteht dabei aus einem naturwissenschaftlichen Teil für die Abschätzung der tatsächlichen Leistungen und einem 
ökonomischen Teil für die Monetarisierung. Bisher ist die Datenlage auf naturwissenschaftlicher Seite lückenhaft. So sind die Kenntnisse über die Hochwasserschutzleistung von Auenwäldern wegen der Modellierungsschwierigkeit und mangelhaften Datenverfügbarkeit noch unvollständig. Auch sind die bisher verfügbaren Daten nicht ausreichend, um abzuschätzen, wie stark sich Ackerland, Grünland und Wald im Hinblick auf Nährstoffretention und Kohlenstoffspeicherung unter verschiedenen Standortbedingungen unterscheiden. Auf ökonomischer Seite stehen mehrere Methoden wie Marktpreismethode, vermiedene Kosten, Ersatzkosten, Schadenskosten und Kontingente Bewertung für die Monetisierung zur Verfügung. In dieser Arbeit wird dafür ein monetärer Wert aus verschiedenen Studien für jede Nutzenkomponente übertragen (Benefit Transfer), da notwendige Daten für das makroskalige Untersuchungsgebiet (Niedersachsen) nicht vorliegen. Obwohl die Übertragbarkeit und Vergleichbarkeit sehr kritisch betrachtet werden müssen, liefert das Verfahren Ergebnisse, um eine erste Schätzung für die Politik zu ermöglichen.

Ein wesentlicher Vorteil des hier dargestellten Vorgehens besteht darin, dass das Faktorensystem flexibel ist und daher gegebenenfalls verschiedenen politischen Zielen anpasst werden kann. Aus Abb. 11 ist ersichtlich, dass keine Flächen in den Weserauen ausgewählt sind. Dies liegt daran, dass der Auenzustand der Weser schlecht ist. Wenn eine Verbesserung der Weserauen politisch erwünscht ist, kann der derzeit limitierende AuswahlFaktor des Zustands rezenter Auen auf Klasse 4 und 5 erweitert werden, wodurch es zur Auswahl zahlreicher Flächen in den Weserauen kommt. 


\section{Literatur}

Barth, N.-C. (2014): Bewertung der Ökosystemdienstleistung Hochwasserschutz am Beispiel eines Auwalds in Hessen. Masterarbeit. Universität Frankfurt, Frankfurt am Main. Institut für Physische Geographie.

Bayerische Landesanstalt für Wald und Forstwirtschaft (2006): Wald - Schutz vor Hochwasser? Beiträge zum Symposium am 27. April 2006. Freising: LWF.

Brombach, H.; Jüpner, R.; Müller, U.; Patt, H.; Richwien, W.; Vogt, R. (2013): Hochwasserschutzmaßnahmen. In Heinz Patt, Robert Jüpner (Eds.): Hochwasser-Handbuch. Auswirkungen und Schutz. Berlin, Heidelberg: Springer Berlin Heidelberg.

Brunotte, E.; Dister, E.; Günther-Diringer, D.; Koenzen, U.; Mehl, D. (2009): Flussauen in Deutschland. Erfassung und Bewertung des Auenzustandes. Bonn-Bad Godesberg: Bundesamt für Naturschutz (Naturschutz und biologische Vielfalt, 87).

Bundesamt für Kartographie und Geodäsie (BKG) (2011): Digitales Landbedeckungsmodell für Deutschland. LBM-DE2009.

Bundesamt für Kartographie und Geodäsie (BKG) (2013): Verwaltungsgebiete 1 : 250000. VG250 und VG250-EW.

Bundesamt für Naturschutz (BfN) (2011): Fachdaten „Flussauen in Deutschland““

Bundesamt für Naturschutz (BfN) (2012): Geodaten aus dem F+E-Vorhaben „Ökosystemfunktionen von Flussauen“.

Bundesministerium für Umwelt Naturschutz und Reaktorsicherheit (BMU) (2007): Nationale Strategie zur biologischen Vielfalt. Vom Bundeskabinett am 7. November 2007 beschlossen. Berlin: Bundesministerium für Umwelt Naturschutz und Reaktorsicherheit.

Bundesministerium für Umwelt Naturschutz und Reaktorsicherheit (BMU) (2008): Deutsche Anpassungsstrategie an den Klimawandel. vom Bundeskabinett am 17. Dezember 2008 vom Bundeskabinett am 17. Dezember 2008 beschlossen. Berlin: Bundesministerium für Umwelt Naturschutz und Reaktorsicherheit.

Bundesministerium für Umwelt Naturschutz und Reaktorsicherheit (BMU) (2011): Der Zustand der biologischen Vielfalt in Deutschland. Der nationale Bericht zur FFH-Richtlinie. Berlin: Bundesministerium für Umwelt Naturschutz und Reaktorsicherheit Referat Öffentlichkeitsarbeit.

Disse, M. (2013): Hydrologische Grundlagen. In Heinz Patt, Robert Jüpner (Eds.): Hochwasser-Handbuch. Auswirkungen und Schutz. Berlin, Heidelberg: Springer Berlin Heidelberg.

Ellenberg, H.; Leuschner, C.; Dierschke, H. (2010): Vegetation Mitteleuropas mit den Alpen. In ökologischer, dynamischer und historischer Sicht. Stuttgart: Ulmer. 
European Energy Exchange AG (EEX) (2014): Geschäftsbericht.

Göttle, A. (2006): Was erwartet die Wasserwirtschaft von der Forstwirtschaft hinsichtlich der Hochwasservorsorge. In : Wald - Schutz vor Hochwasser? Beiträge zum Symposium am 27. April 2006. Freising: LWF.

Grossmann, M.; Hartje, V.; Meyerhoff, J. (2010): Ökonomische Bewertung naturverträglicher Hochwasservorsorge an der Elbe. Bonn-Bad Godesberg: Bundesamt für Naturschutz (Naturschutz und biologische Vielfalt, 89).

Hegg, C. (2006): Waldwirkung auf Hochwasser. In : Wald - Schutz vor Hochwasser? Beiträge zum Symposium am 27. April 2006. Freising: LWF.

Hellberg, C. (2006): Renaturierung von Fließgewässern unter Beachtung des Hochwasserschutzes. Dissertation. Universität Hannover, Hannover. Fakultät für Bauingenieurwesen und Geodäsie.

Jüpner, R. (2013): Hochwasserschutzstrategien. In Heinz Patt, Robert Jüpner (Eds.): Hochwasser-Handbuch. Auswirkungen und Schutz. Berlin, Heidelberg: Springer Berlin Heidelberg.

Koenzen, U. (2005): Fluss- und Stromauen in Deutschland: Typologie und Leitbilder. Ergebnisse des F+E-Vorhabens "Typologie und Leitbildentwicklung für Flussauen in der Bundesrepublik Deutschland" des Bundesamtes für Naturschutz. Bonn-Bad Godesberg: Bundesamt für Naturschutz.

Koenzen, U. (2013): Entwicklungspotenziale von Auen und Flusslandschaften. BfN. Available online at http://www.bfn.de/fileadmin/MDB/documents/ina/vortraege/2013/2013Auen-03_Koenzen_Entwicklungspotenziale_Auen.pdf, checked on 1/12/2015.

Konold, W. (2006): Inwieweit trägt eine angepasste Landnutzung zum Hochwasserschutz bei? In : Wald - Schutz vor Hochwasser? Beiträge zum Symposium am 27. April 2006. Freising: LWF.

Landesamt für Statistik Niedersachsen (LSN) (2015): Kaufwerte für landwirtschaftliche Grundstücke.

Landesanstalt für Umweltschutz Baden-Württemberg (2003): Hydraulik naturnaher Fließgewässer. Teil 3 - Rauheits- und Widerstandsbeiwerte für Fließgewässer in BadenWürttemberg. Karlsruhe. Available online at https://www.lubw.badenwuerttemberg.de/servlet/is/14421/hydraulik_teil_3.pdf?command=downloadContent\&filenam e=hydraulik_teil_3.pdf, checked on 1/12/2015.

Meyer, V. (2005): Methoden der Sturmflut-Schadenspotenzialanalyse an der deutschen Nordseeküste. UFZ.

Meyerhoff, J.; Angeli, D.; Hartje, V. (2012): Valuing the benefits of implementing a national strategy on biological diversity: the case of Germany. In Environmental Science and Policy 23, pp. 109-119. 
Mosner, E.; Leyer, I.; Schneider, S.; Lehmann, B.; Galonska, H. (2010): Praxisleitfaden zur Weichholzauen-Etablierung an Bundeswasserstraßen. Ein Beitrag zum naturverträglichen Hochwasserschutz. Deutsche Bundesstiftung Umwelt. Available online at http://www.unimarburg.de/fb17/fachgebiete/naturschutz/naturschutzbiologie/praxis/leitfadenkoweb.pdf, checked on 1/12/2015.

Niedersächsischer Landesbetrieb für Wasserwirtschaft, Küsten- und Naturschutz (NLWKN) (2012): Gebietskulisse Niedersächsisches Auenprogramm. Gebiete mit besonderer Bedeutung für die Entwicklung von Auen und wasserabhängigen Lebensräumen in Niedersachsen.

Niedersächsischer Landesbetrieb für Wasserwirtschaft, Küsten- und Naturschutz (NLWKN) (2013): Hochwassergefahrenkarten und Hochwasserrisikokarten. Available online at http://www.nlwkn.niedersachsen.de/wasserwirtschaft/eghochwasserrisikomanagementrichtlini e/gefahren_und_risikokarten/gefahren--und-risikokarten-116763.html, checked on 1/15/2015.

Niedersächsisches Ministerium für Umwelt, Energie und Klimaschutz (NMUEK) (2012): Niedersächsisches Auenprogramm. Programm zum Schutz und zur Entwicklung seltener Lebensräume und Arten sowie zur Wiedervernetzung von Lebensräumen. Hannover. Available online at http://www.umwelt.niedersachsen.de/download/73648, checked on $1 / 12 / 2015$.

Niekamp, O.; Piroth, K. (2013): Hochwasserschäden. In Heinz Patt, Robert Jüpner (Eds.): Hochwasser-Handbuch. Auswirkungen und Schutz. Berlin, Heidelberg: Springer Berlin Heidelberg.

Patt, H.; Jüpner, R. (2013): Einführung in die Thematik. In Heinz Patt, Robert Jüpner (Eds.): Hochwasser-Handbuch. Auswirkungen und Schutz. Berlin, Heidelberg: Springer Berlin Heidelberg.

Patt, H.; Jüpner, R. (Eds.) (2013): Hochwasser-Handbuch. Auswirkungen und Schutz. Berlin, Heidelberg: Springer Berlin Heidelberg.

Rieger, W. (2012): Prozessorientierte Modellierung dezentraler Hochwasserschutzmaßnahmen. Dissertation. Universität der Bundeswehr, München.

Schmidt, T. G.; Osterburg, B.; Laggner, A. (2007): Datenauswertung zur Quantifizierung diffuser Stickstoffemissionen aus der Landwirtschaft im Rahmen des Projekts „Integriertes Monitoring des chemischen Zustandes des Grundwassers“ in Niedersachsen. Top-DownAnsatz mit Daten der Agrarstrukturerhebungen 1999 und 2003 und Analyse des Landnutzungswandels. Braunschweig. Available online at http://www.econstor.eu/bitstream/10419/39417/1/548945284.pdf, checked on 12/2/2016.

Scholz, M.; Cierjacks, A.; Kasperidus, H. D.; Schulz-Zunkel, C.; Rupp, H.; Steinmann, A.; Krüger, F. (2012): Kohlenstoffvorrat in Flussauen. In Mathias Scholz, Dietmar Mehl, Christiane Schulz-Zunkel, Hans Dieter Kasperidus, Wanda Born, Klaus Henle (Eds.): Ökosystemfunktionen von Flussauen. Analyse und Bewertung von Hochwasserretention, Nährstoffrückhalt, Kohlenstoffvorrat, Treibhausgasemissionen und Habitatfunktion : 
Ergebnisse des F+E-Vorhabens. Bonn-Bad Godesberg: Bundesamt für Naturschutz (Naturschutz und biologische Vielfalt, 124), pp. 73-85.

Scholz, M.; Kasperidus, H. D.; Ilg, C.; Henle, K. (2012): Habitatfunktion. In Mathias Scholz, Dietmar Mehl, Christiane Schulz-Zunkel, Hans Dieter Kasperidus, Wanda Born, Klaus Henle (Eds.): Ökosystemfunktionen von Flussauen. Analyse und Bewertung von Hochwasserretention, Nährstoffrückhalt, Kohlenstoffvorrat, Treibhausgasemissionen und Habitatfunktion : Ergebnisse des F+E-Vorhabens. Bonn-Bad Godesberg: Bundesamt für Naturschutz (Naturschutz und biologische Vielfalt, 124), pp. 102-146.

Scholz, M.; Mehl, D.; Schulz-Zunkel, C.; Kasperidus, H. D.; Born, W.; Henle, K. (Eds.) (2012): Ökosystemfunktionen von Flussauen. Analyse und Bewertung von Hochwasserretention, Nährstoffrückhalt, Kohlenstoffvorrat, Treibhausgasemissionen und Habitatfunktion : Ergebnisse des F+E-Vorhabens. Bonn-Bad Godesberg: Bundesamt für Naturschutz (Naturschutz und biologische Vielfalt, 124).

Schulz-Zunkel, C.; Scholz, M.; Kasperidus, H. D.; Krüger, F.; Natho, S.; Venohr, M. (2012): Nährstoffrückhalt. In Mathias Scholz, Dietmar Mehl, Christiane Schulz-Zunkel, Hans Dieter Kasperidus, Wanda Born, Klaus Henle (Eds.): Ökosystemfunktionen von Flussauen. Analyse und Bewertung von Hochwasserretention, Nährstoffrückhalt, Kohlenstoffvorrat, Treibhausgasemissionen und Habitatfunktion : Ergebnisse des F+E-Vorhabens. Bonn-Bad Godesberg: Bundesamt für Naturschutz (Naturschutz und biologische Vielfalt, 124), pp. 4872 .

Schwaller, G.; Tölle, U. (2005): Einfluss von Maßnahmen der Gewässerentwicklung auf den Hochwasserabfluss. Bayerisches Landesamt für Wasserwirtschaft. München.

Sommer, G.; Kröll, R. (2013): Lehrbuch zur Immobilienbewertung. Unter Berücksichtigung der ImmoWertV und der Sachwert-Richtlinie. Köln: Werner.

Storm, P.-C. (2011): Umweltrecht. Wichtige Gesetze und Verordnungen zum Schutz der Umwelt. München: Dt. Taschenbuch-Verl.

Thieken, A. H.; Seifert, I.; Merz, B. (Eds.) (2010): Hochwasserschäden. Erfassung, Abschätzung und Vermeidung. München: Oekom-Verl.

Tröltzsch, J.; Görlach, B.; Lückge, H.; Peter, M.; Sartorius, C. (2012): Kosten und Nutzen von Anpassungsmaßnahmen an den Klimawandel. Analyse von 28 Anpassungsmaßnahmen in Deutschland. Umweltbundesamt (UBA). Dessau-Roßlau. Available online at http://www.bmub.bund.de/fileadmin/bmu-

import/files/pdfs/allgemein/application/pdf/3709_41_121_bf.pdf, checked on 1/12/2015.

Umweltbundesamt (UBA) (2012c): Berichterstattung unter der Klimarahmenkonvention der Vereinten Nationen und dem Kyoto-Protokoll 2012. Nationaler Inventarbericht zum Deutschen Treibhausgasinventar $1990-2010 . \quad$ Available online at http://www.umweltbundesamt.de/sites/default/files/medien/461/publikationen/4292.pdf, checked on 1/12/2015. 
Umweltbundesamt (UBA) (2012b): Best-Practice-Kostensätze für Luftschadstoffe, Verkehr, Strom- und Wärmeerzeugung. Anhang B der „Methodenkonvention 2.0 zur Schätzung von Umweltkosten". Available online

https://www.umweltbundesamt.de/sites/default/files/medien/publikation/long/4485.pdf, checked on 1/12/2015.

Umweltbundesamt (UBA) (2012a): Ökonomische Bewertung von Umweltschäden. Methodenkonvention 2.0 zur Schätzung von Umweltkosten.

Venterink, H. O.; Vermaat, J. E.; Pronk, M.; Wiegman, F.; van der Lee, Guda E. M.; van den Hoorn, Martin W. et al. (2006): Importance of sediment deposition and denitrification for nutrient retention in floodplain wetlands. In Applied Vegetation Science 9 (2), pp. 163-174.

Westermann, G.; Finger, S. (2012): Kosten-Nutzen-Analyse. Einführung und Fallstudien. Berlin: E. Schmidt (ESV basics).

Wienhaus, S. (2008): Nutzung bodenkundlich-hydrogeologischer Informationen zur Ausweisung von Zielgebieten für den Grundwasserschutz. Ergebnisse eines Modellprojektes (NOLIMP) zur Umsetzung der EG-Wasserrahmenrichtlinie. Hannover: Landesamt für Bergbau Energie und Geologie.

Wuestemann, H.; Meyerhoff, J.; Ruehs, M.; Schaefer, A.; Hartje, V. (2014): Financial costs and benefits of a program of measures to implement a National Strategy on Biological Diversity in Germany. In Land Use Policy 36, pp. 307-318. 


\section{Paper 4: Assessing cultural ecosystem services through indicators: A case study of the Weser River in Germany}

\section{Introduction}

The concept of cultural ecosystem services (CES) has been developed with the ecosystem services frameworks (Costanza et al., 1997; Daily, 1997; de Groot et al., 2002; MA, 2003; TEEB, 2010; CICES, 2013), among which MA (2003) becomes the most widely applied framework and serves generally as a starting point for further researches. Over the last decade studies in this field have seen a rapid growth, but compared to other types of ecosystem services, CES still lack of prior research focus and thus remain limited in the empirical assessments with the exception of recreation (Milcu et al., 2013). One of the most important reasons is that CES are often characterized as being subjective, intangible, and difficult to relate to ecosystem structures and functions (Daniel et al., 2012). Based on a survey of local residents, Gee and Burkhard (2010) assessed the current CES of the seascape in the context of offshore wind farming from the west coast of the German North Sea and the intangible values associated with them. Plieninger et al. (2013) performed a spatially explicit participatory study of the complete range of CES perceived by local people living in a cultural landscape in Eastern Germany using a combination of mapping exercises and structured interviews. Bieling (2014) presented a hermeneutical in-depth analysis of short stories written by local residents about their thoughts on life in the Swabian Alb (Germany), showing that these stories reveal rich evidences regarding connections to CES. In these cases CES are built on individual perceptions using qualitative information, however, personal evaluation is not the only way to indicate CES (Hernández-Morcillo et al., 2013; van Reeth, 2014; Church et al., 2014). 
This paper attempts to make an effort in this direction by identifying the concrete indicators for each cultural service of the Weser River in Germany. In order to keep the consistency of terms related to CES prevalent in the literature, we base our study on the definitions and categories of Millennium Ecosystem Assessment. Cultural services are defined as "the nonmaterial benefits people obtain from ecosystems through spiritual enrichment, cognitive development, reflection, recreation and aesthetic experiences", and can be distinguished into following categories (MA, 2003):

- Sense of place. Many people value the "sense of place" that is associated with recognized features of their environment, including aspects of the ecosystem.

- Cultural heritage. Many societies place high value on the maintenance of either historically important landscapes ("cultural landscapes") or culturally significant species.

- Spiritual and religious. Many religions attach spiritual and religious values to ecosystems or their components.

- Inspirational. Ecosystems provide a rich source of inspiration for art, folklore, national symbols, architecture, and advertising.

- Educational. Ecosystems and their components and processes provide the basis for both formal and informal education in many societies.

- Aesthetic. Many people find beauty or aesthetic value in various aspects of ecosystems, as reflected in the support for parks, "scenic drives," and the selection of housing locations.

- Recreation and tourism. People often choose where to spend their leisure time based in part on the characteristics of the natural or cultivated landscapes in a particular area. 


\section{Identifying the indicators}

It is evident that human society and natural environment are intimately interconnected. While humankind has always shaped its surrounding environment, ecological systems have in turn influenced human cultures. Cultural services, like all other ecosystem services, must demonstrate a certain relationship between ecosystems in the biophysical domain and human needs and wants in the social domain, although some cultural services may have little dependence on ecosystems. Cultural services are often characterized as being subjective, but subjectivity relates to all ecosystem services to some extent, because to qualify as a service, the selection of ecological structures and functions as well as their particular characteristics changes with knowledge, technical and social development. Furthermore, all services derived from ecosystems cannot be realized without incorporating social input, although CES may depend on them to a greater degree and in extreme cases (Pilgrim and Pretty, 2010; Daniel et al., 2012; Chan et al., 2012a; Chan et al., 2012b). We recognize the intangible property of CES (Chan et al., 2011) and thus suggest the "tangiblization" of the intangibles. Indicators can best serve this aim, because they are usually selective representations of a phenomenon and imply the use of a certain type of data, knowledge and expertise. In the following, we identify the indicators for each type of CES and give reasons for the selections.

\subsection{Sense of place}

Ecosystems give people a sense of place because their elements make a place special or unique as well as foster a sense of authentic human attachment and belonging (HernándezMorcillo et al., 2013). This is also referred to as cultural identity, which is the current cultural linkage between humans and their environments (MA, 2005). Here we suggest current civic coats of arms that may embody one kind of such linkage as the indicator. 
Coat of arms emerged in the middle of the twelfth century over a wide area of Europe for the practical purpose of identifying the unrecognizable warriors in armor on the battlefield. It became very soon the identification symbol of families, and later extended to the whole nobility and the higher clergy, to all social classes, further to all local authorities. At the beginning of the 13th century in Germany, arms of cities and market towns emerged from the seals. These coats of arms were originally self-assumed but came to be granted and controlled by the emperor, kings or sovereigns. In the course of time granting a coat of arms when a new city was founded or when a village was raised to the status of a city became the rule. In contrast to urban districts, municipalities and (rural) districts began to introduce coats of arms only since $1920 \mathrm{er}$, and used them in a great extent after 1945 with the amalgamation and reconstruction. The acquisition of new civic coats of arms today is no longer being granted officially, rather the local authorities decide on their own responsibilities for the acceptance or change of arms. With few exceptions, civic coats of arms consist only of an escutcheon. In the design of modern civic arms special importance is placed consciously on home awareness (Leonhard, 1976; Woodcock and Robinson, 1989; Hildebrandt, 2007). Against this background, it is reasonable to assume that the current escutcheon of local authority with symbols delineating the surrounding ecosystem is able to represent, at least partly, the sense of place this ecosystem provides to the local people.

\subsection{Cultural heritage}

MA (2005) conceptualizes the heritage values as "memories in the landscape from past cultural ties". A large part of cultural heritage is associated with special features of ecosystems that remind people of their historic roots, both collectively and individually. Daniel et al. (2012) and Tengberg et al. (2012) argue that both tangible aspects such as 
physical artifacts or places and intangible aspects like myths, legends or languages, transmitted from generation to generation, are relevant to cultural heritage as CES. In this paper we follow the definition of the cultural heritage by United Nations Educational, Scientific and Cultural Organization (UNESCO) that cultural heritage includes monuments, groups of buildings and sites (UNESCO, 1972), which means that only visible material objects are to be taken into account here. Intangible aspects are considered by UNESCO as the intangible cultural heritage (UNESCO, 2003), and can be understood as the inspirational services in the framework of MA (2003).

Rivers in the pre-modern times are generally deemed geographical obstacles to be crossed, the most effective natural communication lines to travel or freight before trains, automobiles and airplanes are invented, and potential risks for the nearby settlements owing to the flood. The cultural relationship between rivers and people living around them is accordingly represented by the objects connecting both banks of rivers such as bridges, tunnels and ferries, by the improvements or modifications of waterways for the navigation including canals and harbors, as well as by the constructions of barrages and dikes for altering the water flow and preventing floods. Therefore, bridges, tunnels, ferries, canals, harbors, barrages and dikes are chosen as the indicator for this CES.

\subsection{Spiritual and religious}

People often search for spiritual connections to their environment through personal reflection, organized rituals or traditional taboos. Ecosystems provide an important medium for this orientation in time and space, which is reflected by spiritual values placed on certain 
ecosystems or species (MA, 2005). Logically, a certain part of an ecosystem, an ecosystem as a whole, or certain species living in the ecosystem can be the indicators.

\subsection{Inspirational}

Ecosystems inspire an almost unlimited array of representations in art, writings and so on, which remind us consciously or subconsciously of our ties with nature and shape our views and appreciation of the represented ecosystems. Five types of inspirational services are distinguished: verbal art and writings including legends, poems, fictions etc.; performing arts including music, songs, dance etc.; fine arts including paintings, sculptures, crafts etc.; designs and fashion including home furnishings, clothing etc.; media in general including radios, televisions, films, advertisings, web sites, etc. (MA, 2005). Satterfield and Slovic (2004) provided an example to assess this service through poetry and prose. In this paper we follow their direction and choose legends, poems, proses, novels, songs and paintings as the indicators.

\subsection{Educational}

Generally speaking, ecosystems exist longer than the human race. In the very long period of time ecosystems have recorded the evolutionary traces of the earth and witnessed the human history, from which people can learn the knowledge about their natural environment and obtain the information about their own history. This can be seen as the educational service of ecosystems. Museum is an appropriate indicator of this service because the primary purpose of modern museums is to collect, conserve, research, exhibit, and interpret objects of art, natural history, science and technology, or history for the education of the public (Alexander, 1979). 


\subsection{Aesthetic}

Ecosystems are an important source of aesthetic pleasure for people all over the world. A number of studies about the aesthetic value agree on that people generally show a strong preference for natural over built environments. Most of these studies use photographs or prices of real estate as the indicator for aesthetic service (MA, 2005). But as an indicator, photographs depend on the photographer and can be easily manipulated, while prices of real estate are more limited to provide information about the actual ecosystems, both of them reflect the beauty of nature in an indirect way. Therefore, we suggest here observation platforms as the indicator. Observation platforms are usually constructed for the purpose of better seeing sceneries and getting aesthetic enjoyments. They can be part of a building, a tower for example, or be built in the natural topography, on a hilltop for instance. Compared to photographs and prices of real estate, observation platforms provide the possibility to observe directly the elements and features of an ecosystem, thus they are able to serve as the medium of the aesthetic service.

\subsection{Recreation and tourism}

Ecosystems have important value as a place where people can engage in some form of naturebased recreational activities, such as walking, biking, swimming, boating, and camping, which in turn provide an opportunity for many people to experience the benefits of ecosystem services directly. Thus, recreation and tourism represent a major opportunity and nexus for managing the interaction between ecosystems and people (MA, 2005; Daniel et al., 2012). Noticing that most recreational activities depend on built infrastructure and accessibility, we choose cycle route, swimming areas, landing stages for boating and shipping, and camping sites as the indicator for recreation and tourism service. 


\section{Study area}

The Weser, which is the only large river that lies entirely within German national territory, forms at Hannoversch Münden by the confluence of the rivers Werra and Fulda, flows in northern direction through the Central Upland Ranges and the North German Plain, and empties into the North Sea, having an overall length of 453 kilometers (Braun et al., 1998). In Roman times there were already traces of human activities along the Weser, which is confirmed by the findings in the river bed or on the banks dating from the first four centuries. The Weser region stayed in turmoil because of foreign warriors who fought each other, built and destroyed for a long period of time until Charles the Great conquered this region, ending such a chaotic situation. He fixed existing roads and founded bishoprics as civil administration supports of this region. Since then a number of important settlements, such as Münden, Hameln, Höxter, Minden, Nienburg and Bremen, began to arise by reason of military or ecclesial relevance (Löbe, 1969). Currently, there are around 1.5 million residents living directly along the Weser River, distributing in 66 municipalities or cities in 16 districts of four federal states (BKG, 2014; Figure 1). 


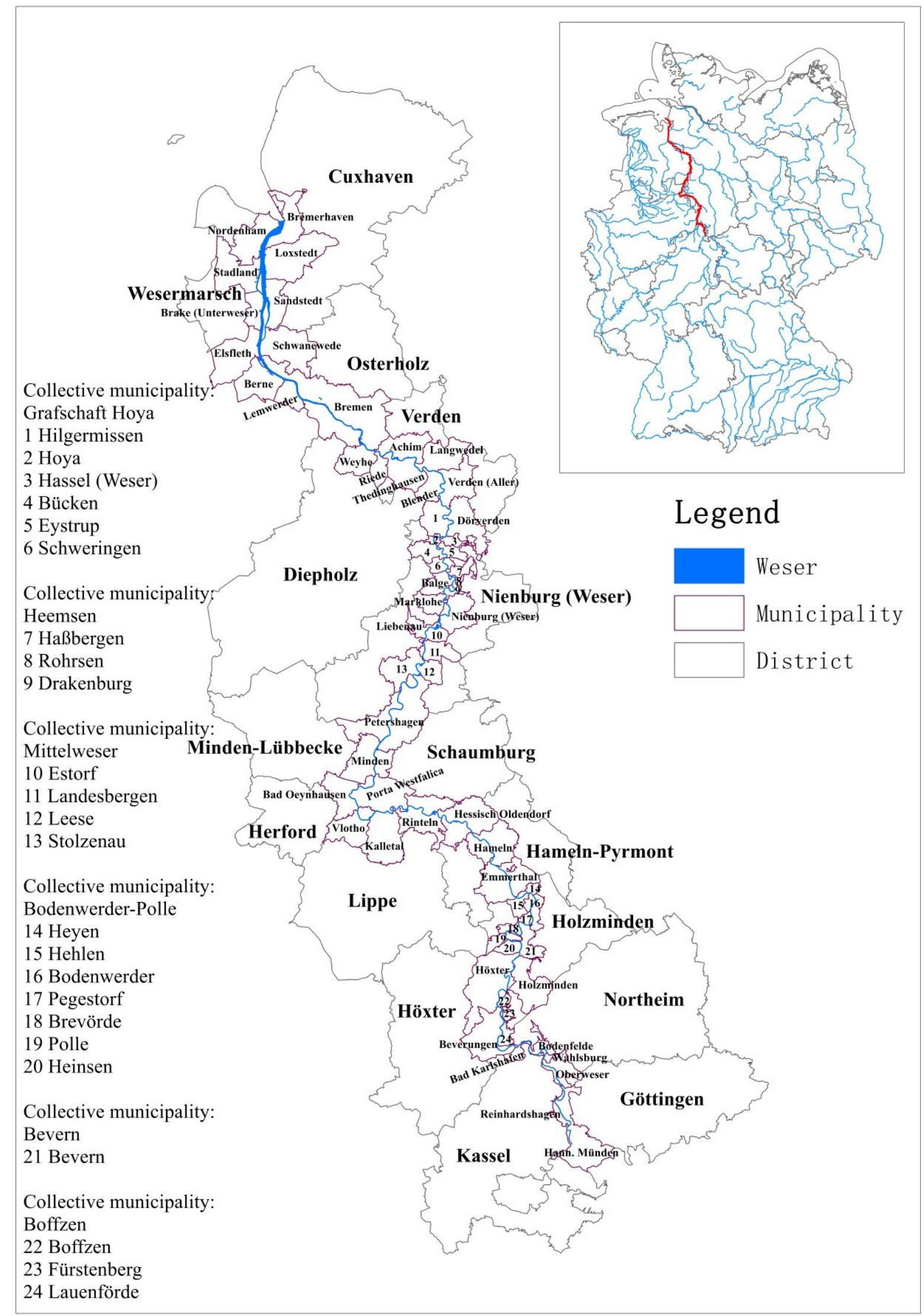

Figure 1: Map of the Weser (based on BKG, 2014) 


\section{Results}

\subsection{Sense of place}

Based on figure 1, we examine the coat of arms of every district, collective municipality and municipality along the Weser. The official explanation represents the meaning of the symbols on the coat of arms. If there is no official explanation, assumptions and judgements are made for interpreting the symbols (Table 1).

Table 1: The coats of arms with symbols for the Weser (in the direction downstream)

\begin{tabular}{|c|c|c|c|}
\hline District & $\begin{array}{l}\text { (Collective) } \\
\text { Municipality } \\
\text { or city }\end{array}$ & $\begin{array}{l}\text { Coat of } \\
\text { arms }\end{array}$ & Meaning \\
\hline Northeim & Bodenfelde & & $\begin{array}{l}\text { It is assumed that the silver-and-blue wave- } \\
\text { shaped division hints at the Weser. }\end{array}$ \\
\hline Höxter & & & $\begin{array}{l}\text { The blue waving band stands symbolically for } \\
\text { the Weser, which borders this district in the } \\
\text { east (Veddeler, 2003). }\end{array}$ \\
\hline Holzminden & & & $\begin{array}{l}\text { The silver waving band characterizes the } \\
\text { Weser which is of great importance for this } \\
\text { district (Landkreis Holzminden). }\end{array}$ \\
\hline Holzminden & Lauenförde & & $\begin{array}{l}\text { The blue-and-white waving escutcheon base } \\
\text { represents the Weser (Stadler, 1970). }\end{array}$ \\
\hline Holzminden & $\begin{array}{l}\text { Collective } \\
\text { municipality } \\
\text { Boffzen }\end{array}$ & & \\
\hline Holzminden & Fürstenberg & & $\begin{array}{l}\text { It is assumed that the waving escutcheon base } \\
\text { (blue-and-golden and golden-and-silver) and } \\
\text { the golden waving band indicate the Weser. }\end{array}$ \\
\hline Holzminden & Boffzen & & \\
\hline Holzminden & $\begin{array}{l}\text { Collective } \\
\text { municipality } \\
\text { Bevern }\end{array}$ & 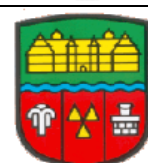 & $\begin{array}{l}\text { It is assumed that the blue waving band } \\
\text { represents the Weser. }\end{array}$ \\
\hline
\end{tabular}




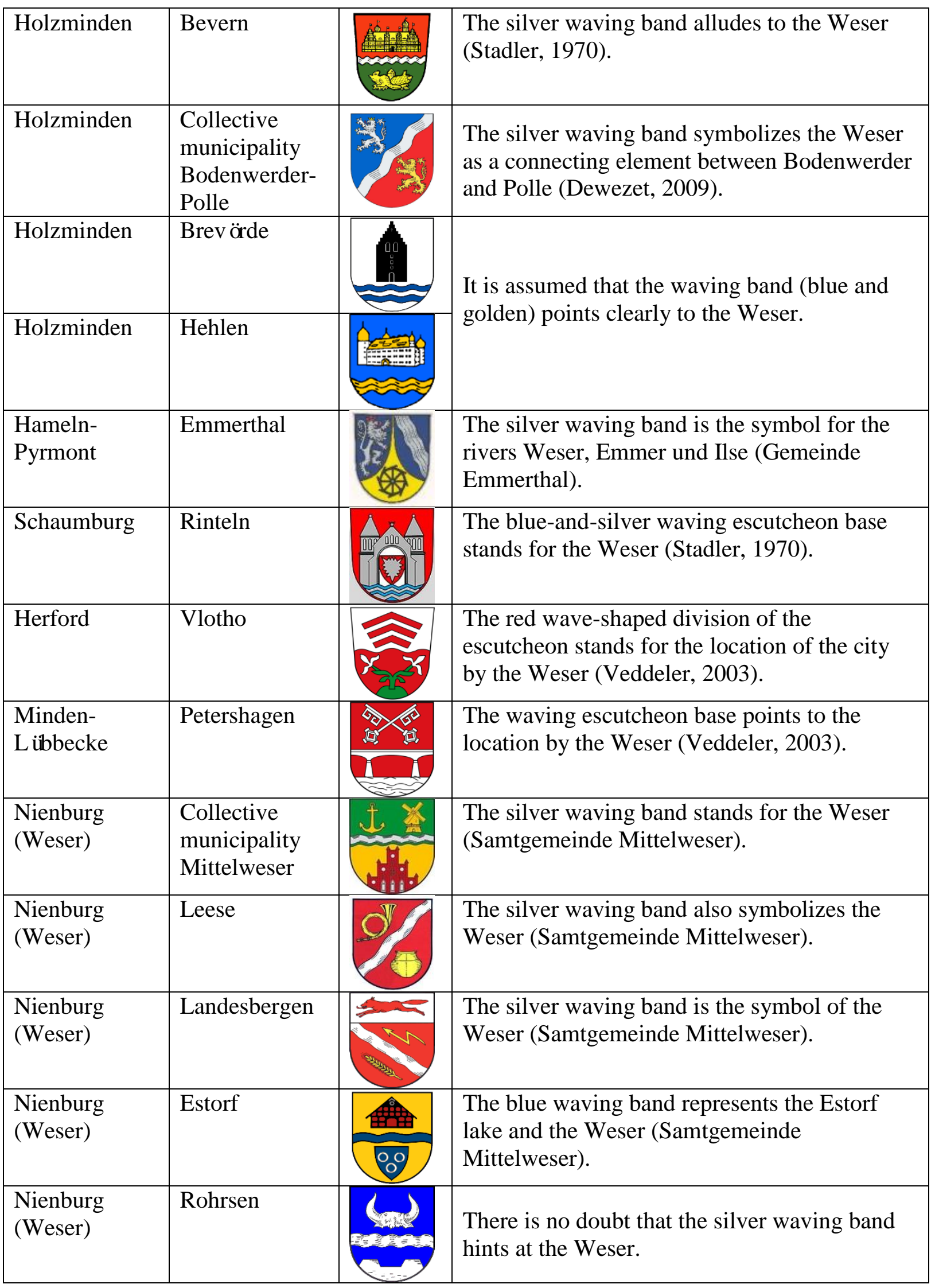




\begin{tabular}{|c|c|c|c|}
\hline $\begin{array}{l}\text { Nienburg } \\
\text { (Weser) }\end{array}$ & Haßbergen & $\mathbb{1}$ & \\
\hline $\begin{array}{l}\text { Nienburg } \\
\text { (Weser) }\end{array}$ & $\begin{array}{l}\text { Collective } \\
\text { municipality } \\
\text { Grafschaft } \\
\text { Hoya }\end{array}$ & & $\begin{array}{l}\text { It is clear that the blue waving band refers to } \\
\text { the Weser. }\end{array}$ \\
\hline $\begin{array}{l}\text { Nienburg } \\
\text { (Weser) }\end{array}$ & Schweringen & & $\begin{array}{l}\text { The golden waving band stands for the Weser, } \\
\text { because the Weser is the geographical center of } \\
\text { this municipal area (Samtgemeinde Hoya). }\end{array}$ \\
\hline $\begin{array}{l}\text { Nienburg } \\
\text { (Weser) }\end{array}$ & Eystrup & & $\begin{array}{l}\text { It is clear that the silver waving band } \\
\text { associates with the Weser. }\end{array}$ \\
\hline $\begin{array}{l}\text { Nienburg } \\
\text { (Weser) }\end{array}$ & Hilgermissen & & $\begin{array}{l}\text { The golden waving band symbolizes the Weser } \\
\text { as eastern boundary of the municipality } \\
\text { (Samtgemeinde Hoya). }\end{array}$ \\
\hline Verden & & & $\begin{array}{l}\text { The golden waving band makes it clear that the } \\
\text { landscape of the district is determined by the } \\
\text { Weser and the Aller (Landkreis Verden). }\end{array}$ \\
\hline Verden & Dörverden & & $\begin{array}{l}\text { The silver waving band refers to the rivers } \\
\text { Weser and Aller, which predominantly shape } \\
\text { the landscape and constitute the boundary of } \\
\text { this municipality (Gemeinde Dörverden). }\end{array}$ \\
\hline Verden & Langwedel & & $\begin{array}{l}\text { The silver waving escutcheon base represents } \\
\text { the rivers flowing in this municipality: Weser, } \\
\text { Old Aller, Mühlebach and Goldbach (Flecken } \\
\text { Langwedel). }\end{array}$ \\
\hline Verden & Blender & & $\begin{array}{l}\text { The blue waving escutcheon base stands for } \\
\text { the Weser (Samtgemeinde Thedinghausen). }\end{array}$ \\
\hline Verden & Riede & & $\begin{array}{l}\text { The silver waving band refers to the Weser } \\
\text { (Samtgemeinde Thedinghausen). }\end{array}$ \\
\hline Wesermarsch & & & $\begin{array}{l}\text { The black waving lines represent the Weser } \\
\text { (Landkreis Wesermarsch). }\end{array}$ \\
\hline Wesermarsch & Berne & & $\begin{array}{l}\text { The white-and-blue waving escutcheon base } \\
\text { refers to the Weser (Stadler, 1970). }\end{array}$ \\
\hline Wesermarsch & Elsfleth & & $\begin{array}{l}\text { The black-and-white waving pattern } \\
\text { symbolizes the Lower Weser (Stadler, 1970). }\end{array}$ \\
\hline
\end{tabular}




\begin{tabular}{|l|l|l|l|}
\hline Wesermarsch & $\begin{array}{l}\text { Brake } \\
\text { (Unterweser) }\end{array}$ & $\begin{array}{l}\text { The blue waving escutcheon base emphasizes } \\
\text { the importance of shipping on the Lower } \\
\text { Weser for this city (Stadler, 1970). }\end{array}$ \\
\hline Cuxhaven & Sandstedt & $\begin{array}{l}\text { It is assumed that the blue waving band refers } \\
\text { to the Weser. }\end{array}$ & \\
\hline Cuxhaven & Loxstedt & & $\begin{array}{l}\text { The silver waving band indicates the rivers } \\
\text { Weser and Lune that flow through this area } \\
\text { (Gemeinde Loxstedt). }\end{array}$ \\
\hline
\end{tabular}

There are totally 16 districts, 8 collective municipalities and 66 municipalities along the Weser, of which 4 districts (25\%), 5 collective municipalities (63\%) and 28 municipalities (42\%) have the Weser as a symbol on the coat of arms (Table 2).

Table 2: Statistic for coat of arms along the Weser

\begin{tabular}{|l|l|l|l|}
\hline & Number & Number with Weser & Percent \\
\hline District & 16 & 4 & $25 \%$ \\
\hline Collective municipality & 8 & 5 & $63 \%$ \\
\hline Municipality & 66 & 28 & $42 \%$ \\
\hline Sum & 90 & 37 & $41 \%$ \\
\hline
\end{tabular}

\subsection{Cultural heritage}

There are totally 55 bridges, 23 ferries and one single tunnel across the Weser. The bridges over the Weser cover almost all the structure types such as beam bridge, arch bridge and suspension bridge, and they are used to carry pedestrian, trains or road traffic. As the supplement to bridges serve the ferries on the Weser, which are run privately. The only tunnel across the Weser was constructed from 1998 to 2004 to offer a connection between the cities of Nordenham and Bremerhaven. Total 35 harbors are distributed in the cities and towns along the Weser, the most important and largest of them are located in Bremen and Bremerhaven. The Weser is regulated through seven barrages built in the 20th century in the middle course. Accordingly, for the purpose of navigation seven canals were constructed, 
which also shorten the shipping distance. Furthermore, $353 \mathrm{~km}$ dikes were built for the flood prevention in the lower course of the Weser (Figure 2).

\subsection{Spiritual and religious}

In comparison with the religious significance of the river Ganga to Hindus of India, the Tano River to Asante, the Nile perch to the ancient Egyptians, or the Amazonian dolphin to the most native tribes (Taylor, 2005), there is no strong evidence showing that the Weser River and the species living in the river have any religious meaning to the local Germans.

\subsection{Inspirational}

First, we consider folk legends as the outcome of the inspirational service. The Weser River is generally not the leading character in the German folk legends, but it often plays a nonnegligible role. Paetow (1974) assembled the most beautiful legends in the Weser region. We list those legends in which the Weser River is mentioned in table 3.

Table 3: Folk legends about the Weser (in the direction downstream; translated from Paetow, 1974)

\begin{tabular}{|l|l|l|}
\hline Place & Legend & Excerpts about the Weser \\
\hline $\begin{array}{l}\text { Hann. } \\
\text { Münden }\end{array}$ & $\begin{array}{l}\text { Robber knights on the } \\
\text { Bramburg }\end{array}$ & $\begin{array}{l}\text { "They (the knights) clamped a chain across the } \\
\text { water flow of the Weser, and if a ship sailed } \\
\text { downstream, a bell rang on the castle." }\end{array}$ \\
\hline Höxter & $\begin{array}{l}\text { The first airmail, the } \\
\text { giant's game in Höxter } \\
\text { and the white woman }\end{array}$ & $\begin{array}{l}\text { "This (blood) flowed into the river and dyed the } \\
\text { green Weser wave completely red." }\end{array}$ \\
\hline Pegestorf & $\begin{array}{l}\text { Giants in the Weser } \\
\text { Uplands and the stone } \\
\text { mill }\end{array}$ & $\begin{array}{l}\text { "Thereupon he (the giant) piled up the water mill on } \\
\text { the rocky bank of the Weser and gave it the name } \\
\text { 'stone mill'." }\end{array}$ \\
\hline
\end{tabular}




\begin{tabular}{|c|c|c|}
\hline Lippe & $\begin{array}{l}\text { The king of the } \\
\text { Köterberg }\end{array}$ & $\begin{array}{l}\text { "They (the two sisters) packed the baby boy and } \\
\text { threw him into the Weser." } \\
\text { "The two sisters took the (second) baby boy away } \\
\text { likewise and threw him into the Weser." } \\
\text { "The two evils threw the baby girl also into the } \\
\text { Weser." } \\
\text { "The king's children walked back to the Weser } \\
\text { where the fisherman father held them gladly in his } \\
\text { arms." }\end{array}$ \\
\hline Fürstenberg & $\begin{array}{l}\text { The battle for the } \\
\text { manufacturing secretes } \\
\text { of Fürstenberg's china }\end{array}$ & $\begin{array}{l}\text { "On the morning of July 8th he (son-in-law of } \\
\text { Benkraff) had secretly put up with his sister and let } \\
\text { the ferryman in Boffzen row across the Weser." } \\
\text { "This time they crossed the Weser in the village } \\
\text { Wehrden." }\end{array}$ \\
\hline Bodenwerder & $\begin{array}{l}\text { Münchhausen narrated } \\
\text { in Bodenwerder }\end{array}$ & $\begin{array}{l}\text { "... as the baron used to narrate them (wonderful } \\
\text { journeys) personally with the bottle in the circle of } \\
\text { his friends, made up by the lying baron at the } \\
\text { German Weser, ..." }\end{array}$ \\
\hline Emmerthal & $\begin{array}{l}\text { The Trumpeter of } \\
\text { Grohnde on the } \\
\text { floating ice sheet }\end{array}$ & $\begin{array}{l}\text { "When in winter days all standing water, the pools } \\
\text { and ponds are already under hard ice sheet, then the } \\
\text { flowing Weser still defends itself with its pounding } \\
\text { of waves against the deathly rigidity of frost." } \\
\text { "He (the trumpeter) rushed through the alleys, got to } \\
\text { the towpath and looked over the Weser, ..., in the } \\
\text { hours of festivity the Weser had been alive again." }\end{array}$ \\
\hline Emmerthal & $\begin{array}{l}\text { The mariners of the } \\
\text { Weser and the cat of } \\
\text { Hajen }\end{array}$ & $\begin{array}{l}\text { "When in those days a Weser ship with full load,..., } \\
\text { went downward on the Weser, then eight men } \\
\text { (called Hüossen) were probably necessary to } \\
\text { conduct this ark (called Weserbock)." } \\
\text { "Then such a ship came, pulled up by the Hüossen } \\
\text { on the Weser, over a village,..." }\end{array}$ \\
\hline Hameln & $\begin{array}{l}\text { The Pied Piper of } \\
\text { Hameln }\end{array}$ & $\begin{array}{l}\text { "And thus he (the Pied Piper) led them (rats and } \\
\text { mice) to the Weser, where he gathered up his clothes } \\
\text { and stepped into the water, and all the animals } \\
\text { followed him, entering the water and drowning." }\end{array}$ \\
\hline Hameln & $\begin{array}{l}\text { The bell chain of } \\
\text { Uetzenburg }\end{array}$ & $\begin{array}{l}\text { "The robbers also disturbed the ship traffic on the } \\
\text { Weser." }\end{array}$ \\
\hline Rinteln & $\begin{array}{l}\text { The giant king and his } \\
\text { daughter }\end{array}$ & $\begin{array}{l}\text { "Thus he (a knight) lifted her (the daughter of the } \\
\text { giant king) on his warhorse, and they rushed to the } \\
\text { Weser, where the ships already await them. The } \\
\text { wind swelled the sails, the current accelerated the } \\
\text { trip, and the fleet fled downstream to the island on } \\
\text { which the castle of victor rose." }\end{array}$ \\
\hline
\end{tabular}




\begin{tabular}{|c|c|c|}
\hline $\begin{array}{l}\text { Porta } \\
\text { Westfalica }\end{array}$ & $\begin{array}{l}\text { How the Westphalian } \\
\text { Pass has arisen (The } \\
\text { Weser is the major } \\
\text { role in this legend; see } \\
\text { also Löbe (1969) about } \\
\text { the ancient river } \\
\text { course of the Weser) }\end{array}$ & $\begin{array}{l}\text { "In old times ... the Weser had to force its water } \\
\text { through the valley of Walluicke in the Wiehen Hills. } \\
\text { Then it crossed the devil's mind that he wanted to } \\
\text { bring the people in the whole Weser valley under his } \\
\text { thumb. ... He carried huge boulders from the } \\
\text { southern hill over here and dammed up the ravine of } \\
\text { Wallücke. The accumulating water mass had now no } \\
\text { more outflow and impounded before the mountains, } \\
\text { rose and spread out, submerged the villages and the } \\
\text { hills, and formed a huge lake." } \\
\text { "Because lightning came down, split the mountain } \\
\text { with terrible thunderclap and opened a gaping } \\
\text { ravine, through which the water could flow out } \\
\text { again like the smoke in the chimney. Slowly the } \\
\text { hills rose from the floods again like islands, the } \\
\text { fields and houses emerged, and the Weser returned } \\
\text { to its bed. But its water flew henceforth northward } \\
\text { through the new notch, and thus the Westphalian } \\
\text { Pass arisen. }\end{array}$ \\
\hline $\begin{array}{l}\text { Porta } \\
\text { Westfalica }\end{array}$ & $\begin{array}{l}\text { Wieland came to the } \\
\text { Weser and made a } \\
\text { dugout }\end{array}$ & $\begin{array}{l}\text { "His (Wieland) next destination was the Weser, } \\
\text { there, as it says explicitly, 'where the sea was no } \\
\text { more far'." } \\
\text { "So he arrived before the Great Weser Gate, which } \\
\text { is today called Porta Westfalica, at the old Castle } \\
\text { Rehme (now Bad Oeynhausen), and hid himself } \\
\text { with his treasures in the forests by the river." } \\
\text { "Then the skillful young man boarded his ship, } \\
\text { swung out to the middle of the river, and rowed } \\
\text { quite comfortably and effortlessly down the Weser." } \\
\text { "The river was getting wider and more powerful, } \\
\text { and finally the ship had passed through the mouth of } \\
\text { the Weser,..." }\end{array}$ \\
\hline Vlotho & $\begin{array}{l}\text { The lords of Vlotho on } \\
\text { the Amtshausberg }\end{array}$ & $\begin{array}{l}\text { "The merchant quickly pulled himself together, and } \\
\text { both fled secretly through dark corridors down the } \\
\text { Castle Hill to the Weser, where a little ship lay } \\
\text { hidden in the reeds. At dawn the lovers rowed along } \\
\text { the bank to their hometown. The current drifted } \\
\text { them inexorably forward." }\end{array}$ \\
\hline Petershagen & $\begin{array}{l}\text { The shepherd of } \\
\text { Petershagen }\end{array}$ & $\begin{array}{l}\text { "A shepherd was grazing between Petershagen and } \\
\text { Windheim his herd on a green meadow near the } \\
\text { Weser. The sun sank and the moon came up with its } \\
\text { stars, and the shepherd was still sitting on the bank } \\
\text { hill by the river. There he was watching something } \\
\text { on the river, floating closer, light as a feather in the } \\
\text { wind. And shortly he saw in the moonlight a figure } \\
\text { standing there on a drifting bed shell in the water." }\end{array}$ \\
\hline
\end{tabular}




\begin{tabular}{|c|c|c|}
\hline $\begin{array}{l}\text { Marklohe } \\
\text { (speculative) }\end{array}$ & $\begin{array}{l}\text { Marklo by the Weser } \\
\text { and the missionaries } \\
\text { from England }\end{array}$ & $\begin{array}{l}\text { "Once a year the counts of Gaus came together to } \\
\text { the large Thing Square by the Weser, which was } \\
\text { called Marklo by them." }\end{array}$ \\
\hline Bücken & $\begin{array}{l}\text { Von Knuflock, who } \\
\text { betrayed the } \\
\text { Hodenbergers }\end{array}$ & $\begin{array}{l}\text { "After a while a count of Hoya also came to the idea } \\
\text { of settling here by the Weser, and he built his castle } \\
\text { on an island in the river." }\end{array}$ \\
\hline Bremen & $\begin{array}{l}\text { The lucky sitting hen } \\
\text { of Bremen }\end{array}$ & $\begin{array}{l}\text { "But everywhere they wanted to settle down, the } \\
\text { legal owners of the land, the farmers and landlords } \\
\text { opposed them and chased these displaced people } \\
\text { back on the Weser River. ... So they sailed from one } \\
\text { bank to another and could gain a foothold nowhere." }\end{array}$ \\
\hline Bremen & $\begin{array}{l}\text { How the Theisenrad } \\
\text { Dike was saved }\end{array}$ & $\begin{array}{l}\text { "What would Bremen probably be without its river } \\
\text { of fate, the powerful Weser? This river is like a } \\
\text { charitable giant, who took people's burden on its } \\
\text { back and advance them according to their will. He } \\
\text { has increased the wealth of the commercial city in } \\
\text { centuries. But from time to time it becomes a rebel } \\
\text { from the faithful servant. Then the unpredictable } \\
\text { water mass swells its body and grabbed with mighty } \\
\text { arms at goods and chattels of people, as if he wanted } \\
\text { reclaim what he has once given in good mood." } \\
\text { "The Bremers have providently drawn boundaries } \\
\text { for it (the Weser) in quiet days, high dikes, behind } \\
\text { which they can then wait, until the aggressive river } \\
\text { has composed itself and returned to its bed. The } \\
\text { most important of all these dikes is the Theisenrad } \\
\text { Dike." }\end{array}$ \\
\hline Bremen & $\begin{array}{l}\text { Till Eulenspiegel and } \\
\text { the milk battle in } \\
\text { Bremen }\end{array}$ & $\begin{array}{l}\text { "Then he (Till Eulenspiegel) climbed out of the } \\
\text { cellar, shook his fool's cap, the little bells ringing } \\
\text { out, and stalked with long spidery legs to the } \\
\text { Weser." }\end{array}$ \\
\hline Bremen & $\begin{array}{l}\text { How the Faulenstrasse } \\
\text { (Lazy Street) in } \\
\text { Bremen got its name }\end{array}$ & $\begin{array}{l}\text { "Only the mother moiled, milked the goats, cooked } \\
\text { cabbages and beets, scooped water from the Weser, } \\
\text { and was the only one who actually stuck the family } \\
\text { together." } \\
\text { "With spade and shovel they (the seven lazy } \\
\text { brothers) firstly dug a deep ditch where the water } \\
\text { could finally flow into the Weser." } \\
\text { "It (the wall) ranged from a sand hill up to the other } \\
\text { and dammed up the flood water of the Weser from } \\
\text { the paternal fields." }\end{array}$ \\
\hline Bremen & $\begin{array}{l}\text { Klaus Störtebeker and } \\
\text { Gödeke Michels of } \\
\text { Verden }\end{array}$ & $\begin{array}{l}\text { "Just on that day the 'Likedeelers' (equal sharers) } \\
\text { had captured a hulk with aged wine on the Weser." }\end{array}$ \\
\hline
\end{tabular}




\begin{tabular}{|l|l|l|}
\hline Lemwerder & $\begin{array}{l}\text { The dike breaching in } \\
\text { Altenesch }\end{array}$ & $\begin{array}{l}\text { "The people in the whole region of Stedingen have } \\
\text { defied and embanked the Weser." } \\
\text { "So it happened once again that the water of the } \\
\text { Weser ascended threateningly to the dike crowns." }\end{array}$ \\
\hline
\end{tabular}

Except for the folk legends, the Weser River also inspires many writers to create a number of literary works in different genres. In table 4 we list the poems, proses, novels, and lyrics of songs about the Weser.

Table 4: Literary works about the Weser (in the direction downstream; based on Below, 2011)

\begin{tabular}{|c|c|c|c|}
\hline Place & Genre & Author & Excerpts about the Weser \\
\hline $\begin{array}{l}\text { Hann. } \\
\text { Münden }\end{array}$ & Poem & $\begin{array}{l}\text { Carl } \\
\text { Natemann }\end{array}$ & $\begin{array}{l}\text { "Where Werra and Fulda kiss } \\
\text { They must atone their names, } \\
\text { And here begins by this kiss } \\
\text { German up to the sea the Weser River." (The } \\
\text { Weser Stone) }\end{array}$ \\
\hline $\begin{array}{l}\text { Hann. } \\
\text { Münden }\end{array}$ & Poem & August Engel & $\begin{array}{l}\text { "There the chimes shake } \\
\text { So lovely to heart and ears, } \\
\text { There the rivers flow like silver } \\
\text { Forth from dark forest."(Engel, 1990) }\end{array}$ \\
\hline Höxter & Poem & $\begin{array}{l}\text { Hoffmann } \\
\text { von } \\
\text { Fallersleben }\end{array}$ & $\begin{array}{l}\text { "How beautiful on the mountains, how } \\
\text { beautiful in the valley! } \\
\text { O Corvey, I greet you many thousand times." } \\
\text { (Von Fallersleben, 1973) }\end{array}$ \\
\hline Holzminden & Novel & $\begin{array}{l}\text { Wilhelm } \\
\text { Raabe }\end{array}$ & $\begin{array}{l}\text { "The young, just flowering leaf buds of the low } \\
\text { shrubs are hung with dewdrops. Some early } \\
\text { white and yellow flowers shine weakly from } \\
\text { the beds in the dusky night. The old river } \\
\text { rustles and grumbles under the wall of the } \\
\text { garden. Leaning on the parapet against the } \\
\text { river, the Monika Fichtner stands and looks out } \\
\text { dreamily shyly over the mirror of the Weser, in } \\
\text { which the stars and the great comet } \\
\text { contemplate their a thousand times refracted } \\
\text { image." (Raabe, 1968) }\end{array}$ \\
\hline Rinteln & $\begin{array}{l}\text { Poem, } \\
\text { also } \\
\text { lyrics of } \\
\text { the } \\
\text { Weser } \\
\text { Song }\end{array}$ & $\begin{array}{l}\text { Franz von } \\
\text { Dingelstedt }\end{array}$ & $\begin{array}{l}\text { "And around me it sounded so glad and so } \\
\text { sublime, } \\
\text { And above me it dawns so bright, } \\
\text { And below roared the distant weir } \\
\text { And sparkling wave of the Weser." (By the } \\
\text { Weser) }\end{array}$ \\
\hline
\end{tabular}




\begin{tabular}{|c|c|c|c|}
\hline $\begin{array}{l}\text { Porta } \\
\text { Westfalica }\end{array}$ & $\begin{array}{l}\text { Lyrics of } \\
\text { the } \\
\text { Weser } \\
\text { Bow } \\
\text { Song }\end{array}$ & Unknown & $\begin{array}{l}\text { "Where the Weser makes a big bow, } \\
\text { Where the Emperor William keeps the faithful } \\
\text { watch, } \\
\text { Where one drinks up half-liters in two gulps, } \\
\text { There is my homeland, there I am at home." } \\
\text { "If I have to once move far in the distance, } \\
\text { the yearning drives me again to the Weser, } \\
\text { From Hann Münden to the North Sea beach, } \\
\text { There is my homeland, my fatherland." }\end{array}$ \\
\hline $\begin{array}{l}\text { Porta } \\
\text { Westfalica }\end{array}$ & Poem & August Engel & $\begin{array}{l}\text { "Now turn! The river moves through the pass, } \\
\text { And before him lies the bleak reality, } \\
\text { And a hope fades after another, } \\
\text { And all remained in the early days; } \\
\text { Then he battles his way through various } \\
\text { miseries, } \\
\text { Until he goes down to the vast sea." (Engel, } \\
\text { 1990) }\end{array}$ \\
\hline Bremen & Novel & Alma Rogge & $\begin{array}{l}\text { "She saw the drifting clouds in the sky, felt the } \\
\text { force of the river, heard the water swoosh and } \\
\text { paid attention to every bird cry." (Rogge, } \\
\text { 1958) }\end{array}$ \\
\hline $\begin{array}{l}\text { The whole } \\
\text { Weser }\end{array}$ & Essay & $\begin{array}{l}\text { Franz von } \\
\text { Dingelstedt }\end{array}$ & $\begin{array}{l}\text { "..., where the Weser flows, mid through } \\
\text { beautiful, though not large mountain forms, } \\
\text { over friendly, but not rich villages, without } \\
\text { steamships and without three-master, but often } \\
\text { fraught with an ark hanging a colorful pennant, } \\
\text { on which blithe people sit and look out or sing } \\
\text { out over the blue water toward the blue } \\
\text { mountains." (Dingelstedt, 1972) }\end{array}$ \\
\hline $\begin{array}{l}\text { The whole } \\
\text { Weser }\end{array}$ & $\begin{array}{l}\text { Lyrics of } \\
\text { the song } \\
\text { "The } \\
\text { German } \\
\text { Rivers" }\end{array}$ & $\begin{array}{l}\text { Mar von } \\
\text { Schenkendorf }\end{array}$ & $\begin{array}{l}\text { "So close to the highly glad land, } \\
\text { Where the earth tyrant's blood drank, } \\
\text { And after disengaged slave band, } \\
\text { The Roman yoke to the ground sank. } \\
\text { Hear, o Weser, our greetings, } \\
\text { They should come jubilantly to you, } \\
\text { With full earnestness and calm dignity, } \\
\text { You, river of freedom, to the ocean flow. } \\
\text { (Marbach, 1841) }\end{array}$ \\
\hline $\begin{array}{l}\text { The whole } \\
\text { Weser }\end{array}$ & Poem & $\begin{array}{l}\text { Franz von } \\
\text { Dingelstedt }\end{array}$ & $\begin{array}{l}\text { "So the Weser bobs childishly up } \\
\text { By mountains comfortably surrounded, } \\
\text { And in dreamful course comes } \\
\text { Through green meadow flowing down. } \\
\text { So it winds with quiet foot } \\
\text { Downstream to the distant sea, } \\
\text { And reflects with loquacious greetings } \\
\text { The bank gentle peace." (Dingelstedt, 1972) }\end{array}$ \\
\hline
\end{tabular}


Equally, painters also get inspired by the Weser (Table 5).

Table 5: Paintings about the Weser (in the direction downstream; based on Kastler and Lüpkes, 2000)

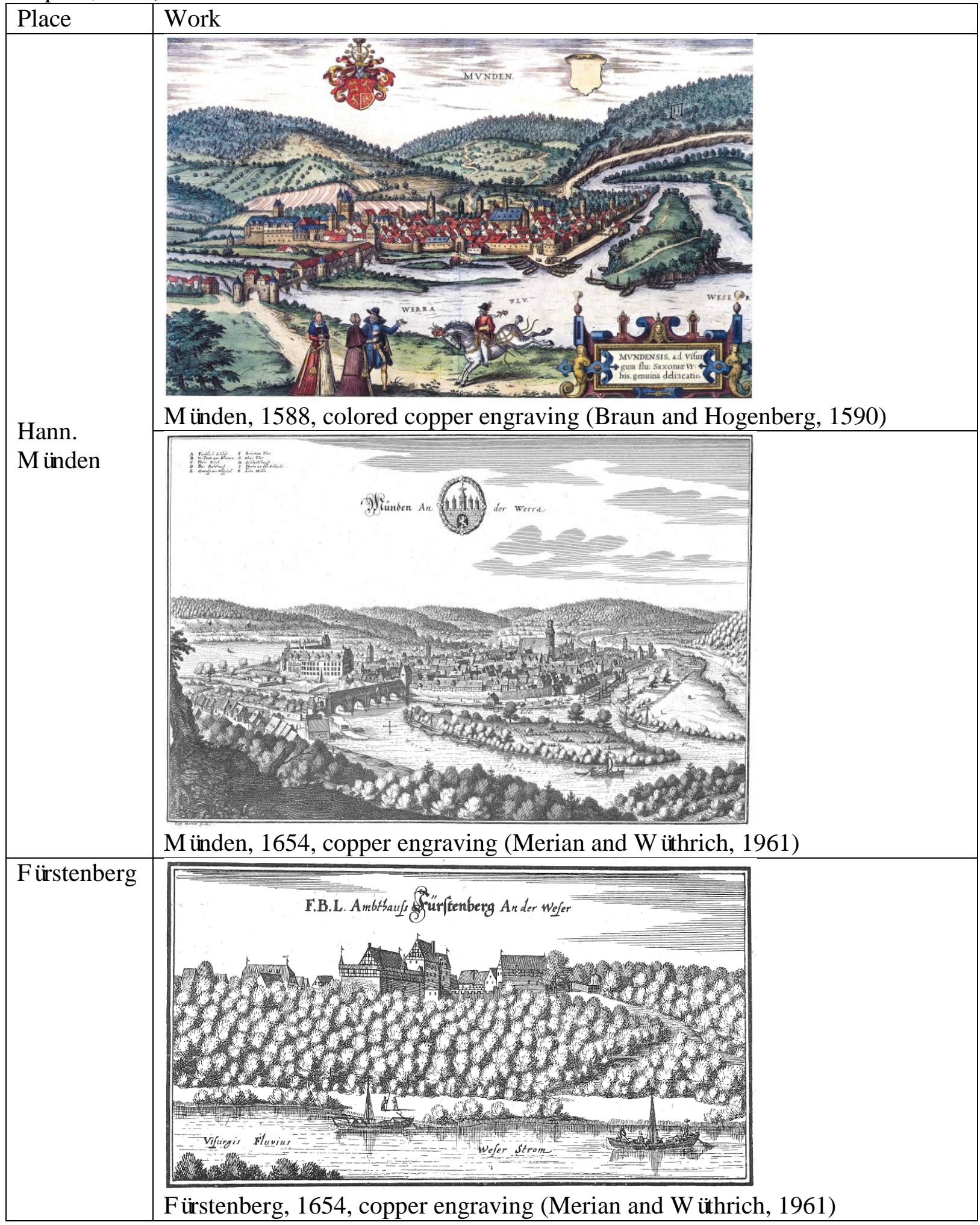




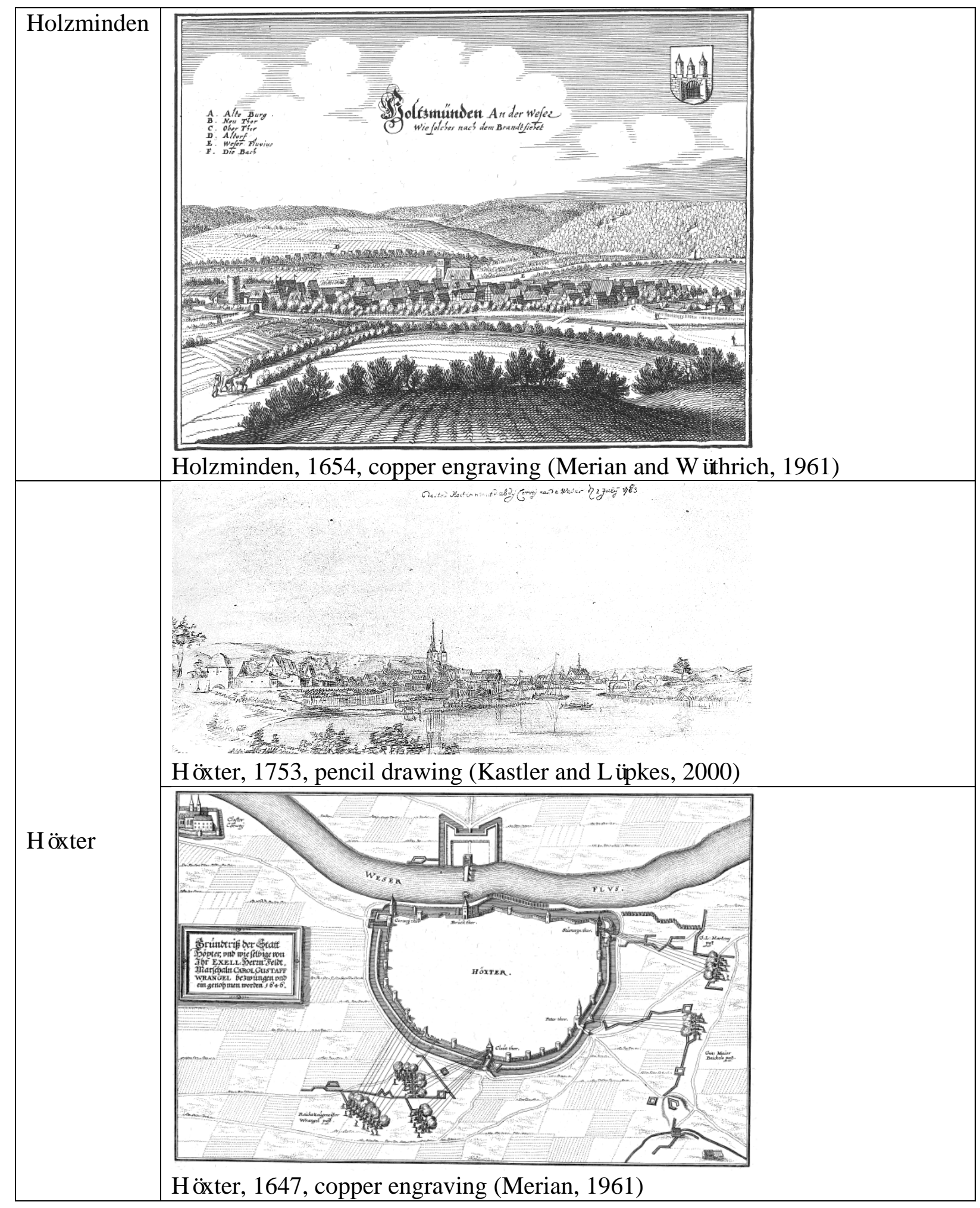




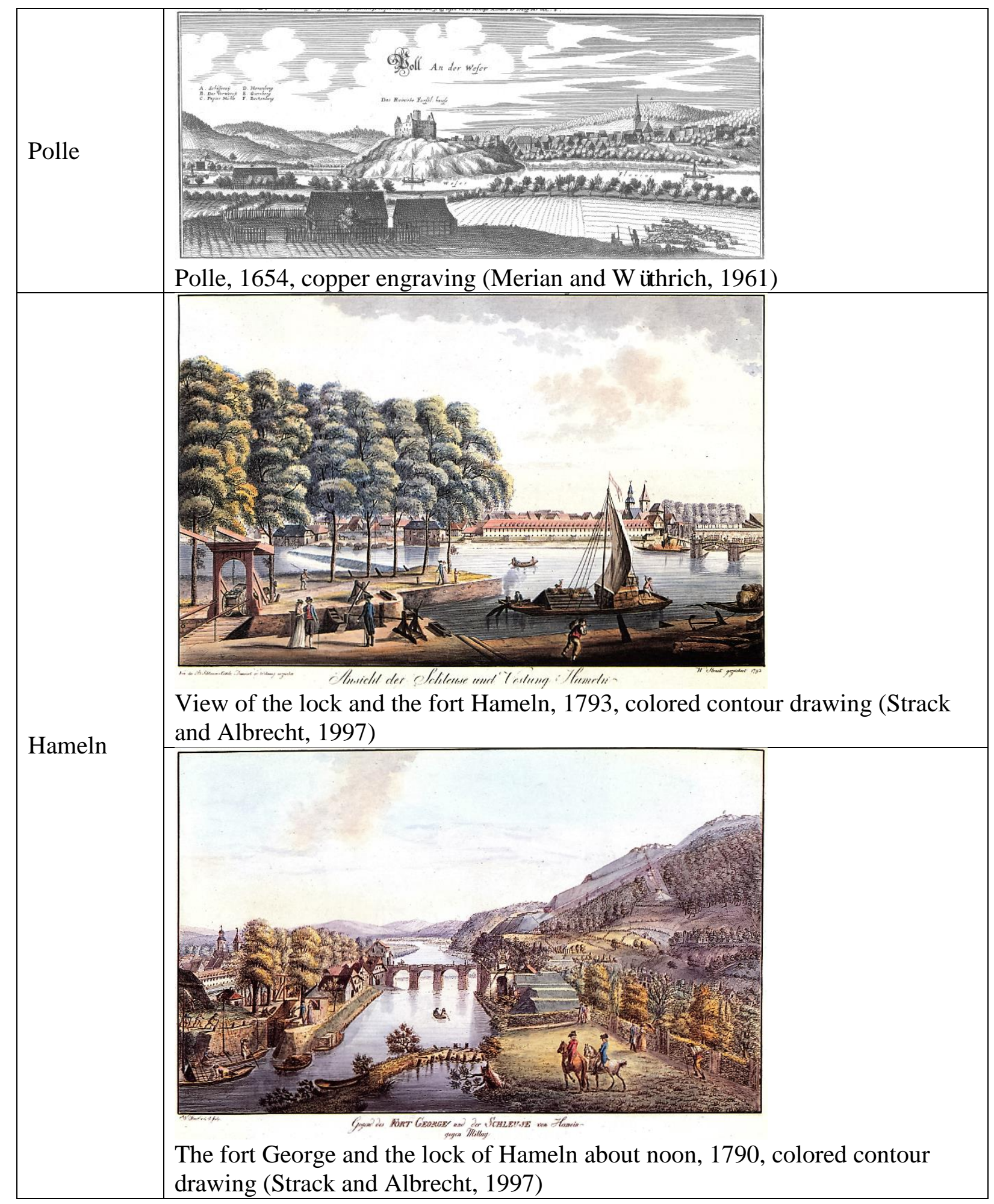




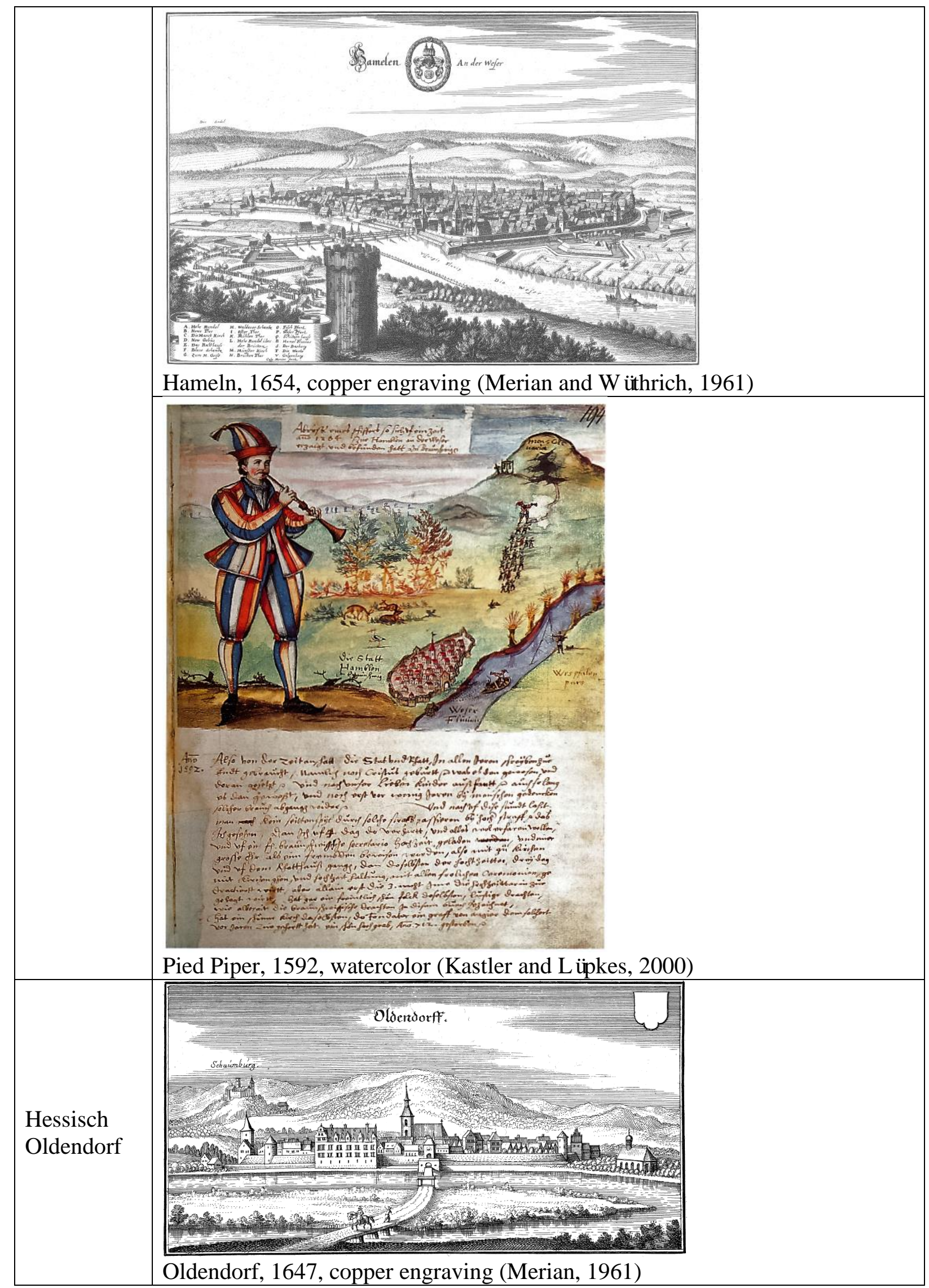

Oldendorf, 1647, copper engraving (Merian, 1961) 


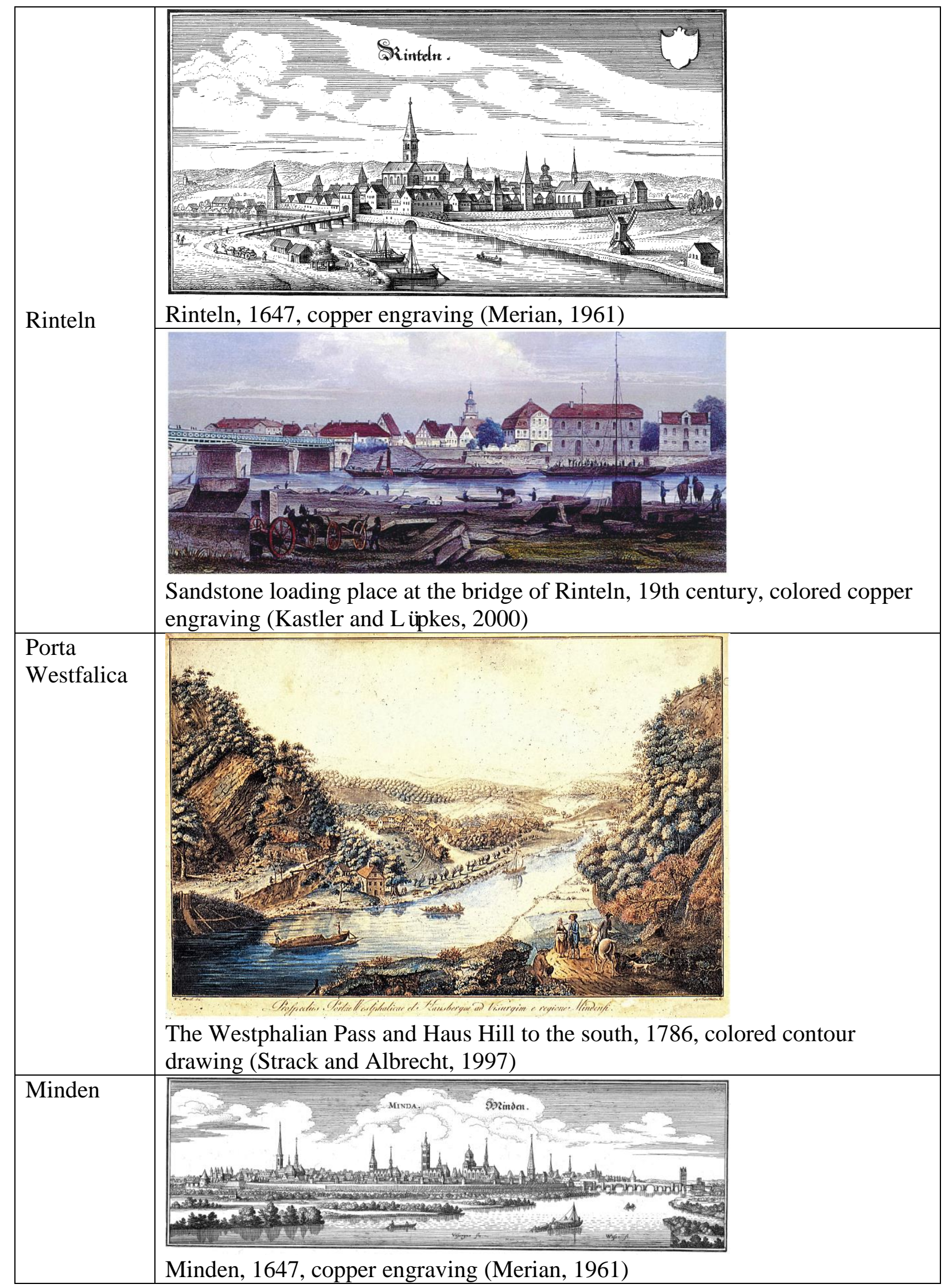




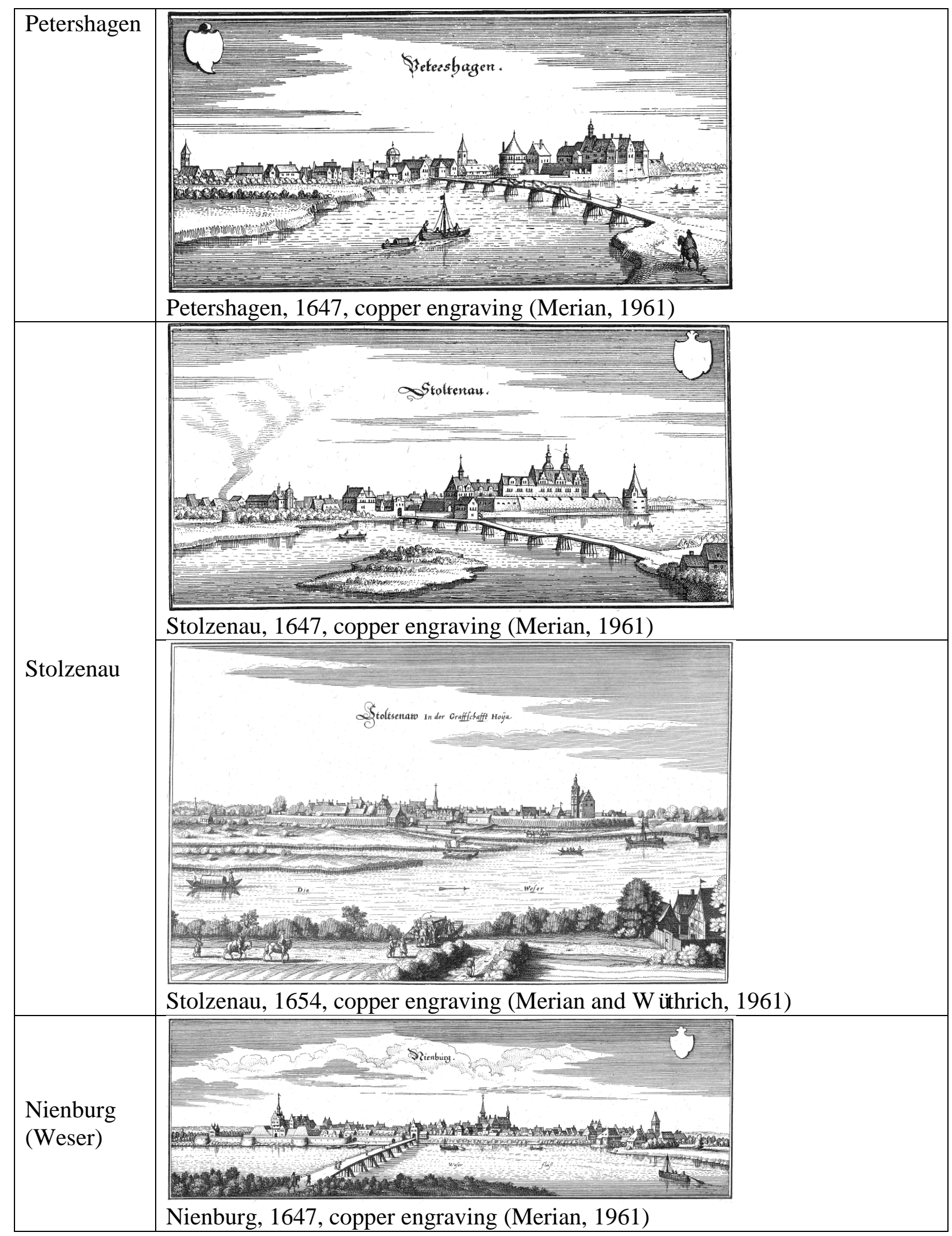




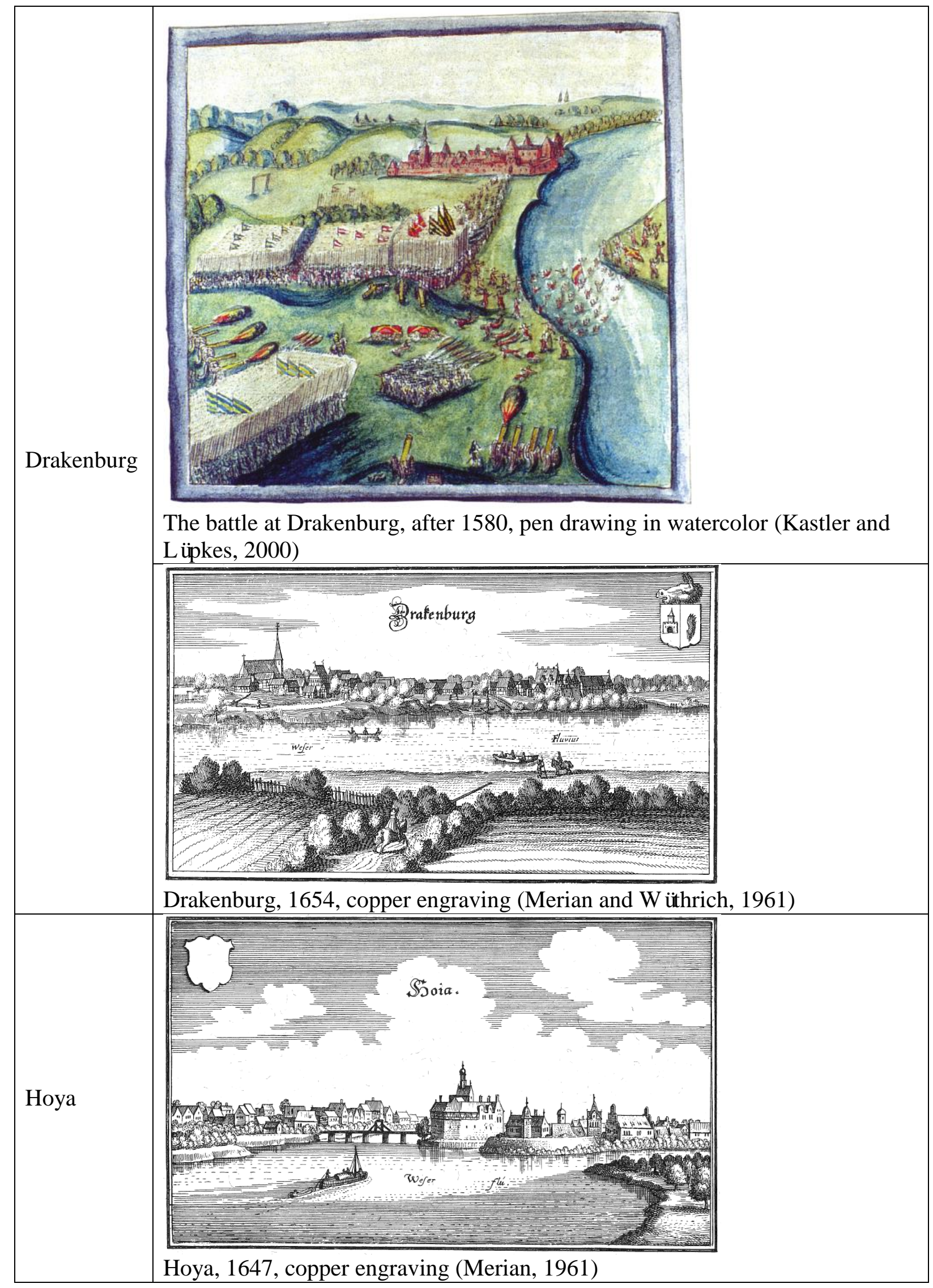




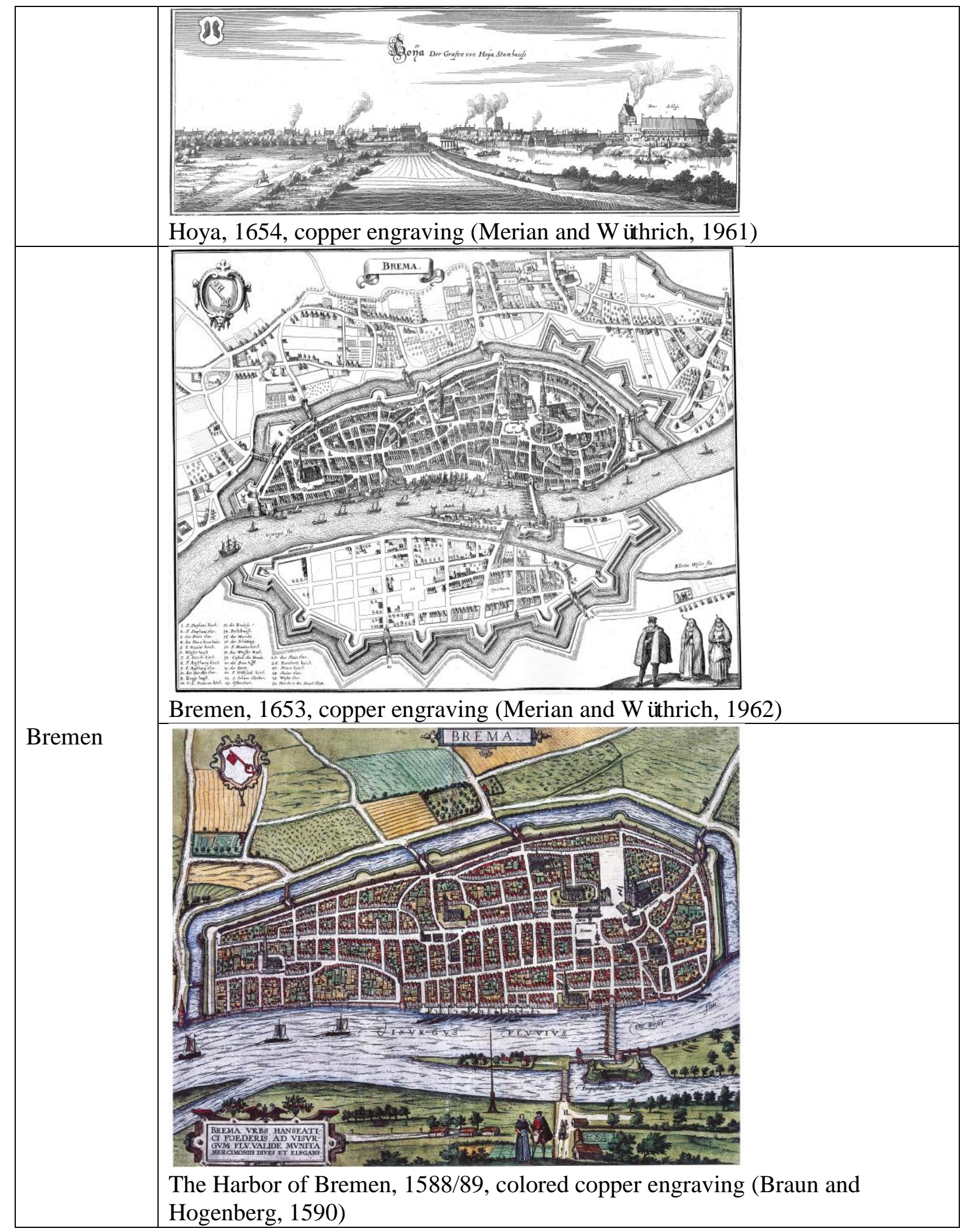




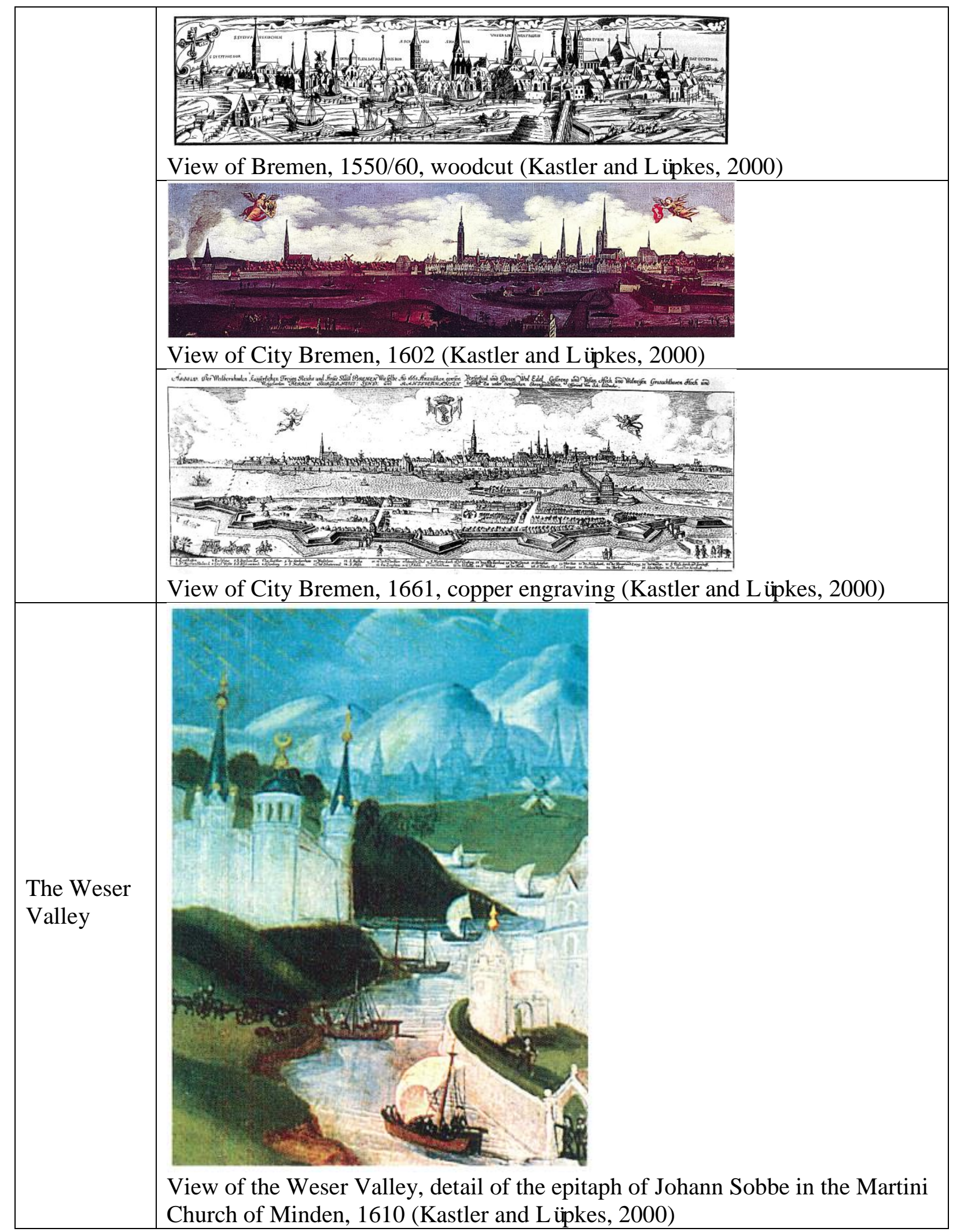




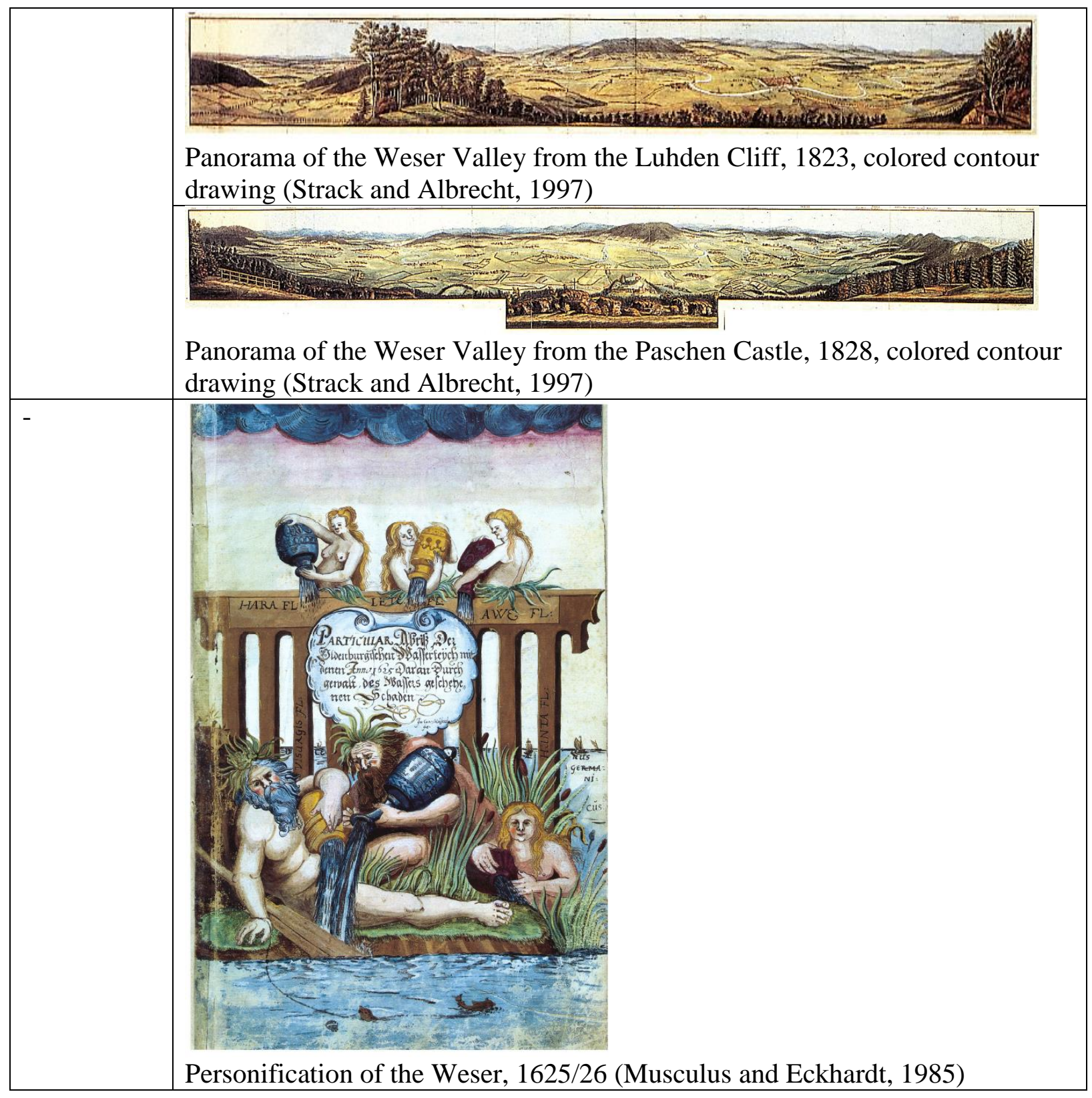




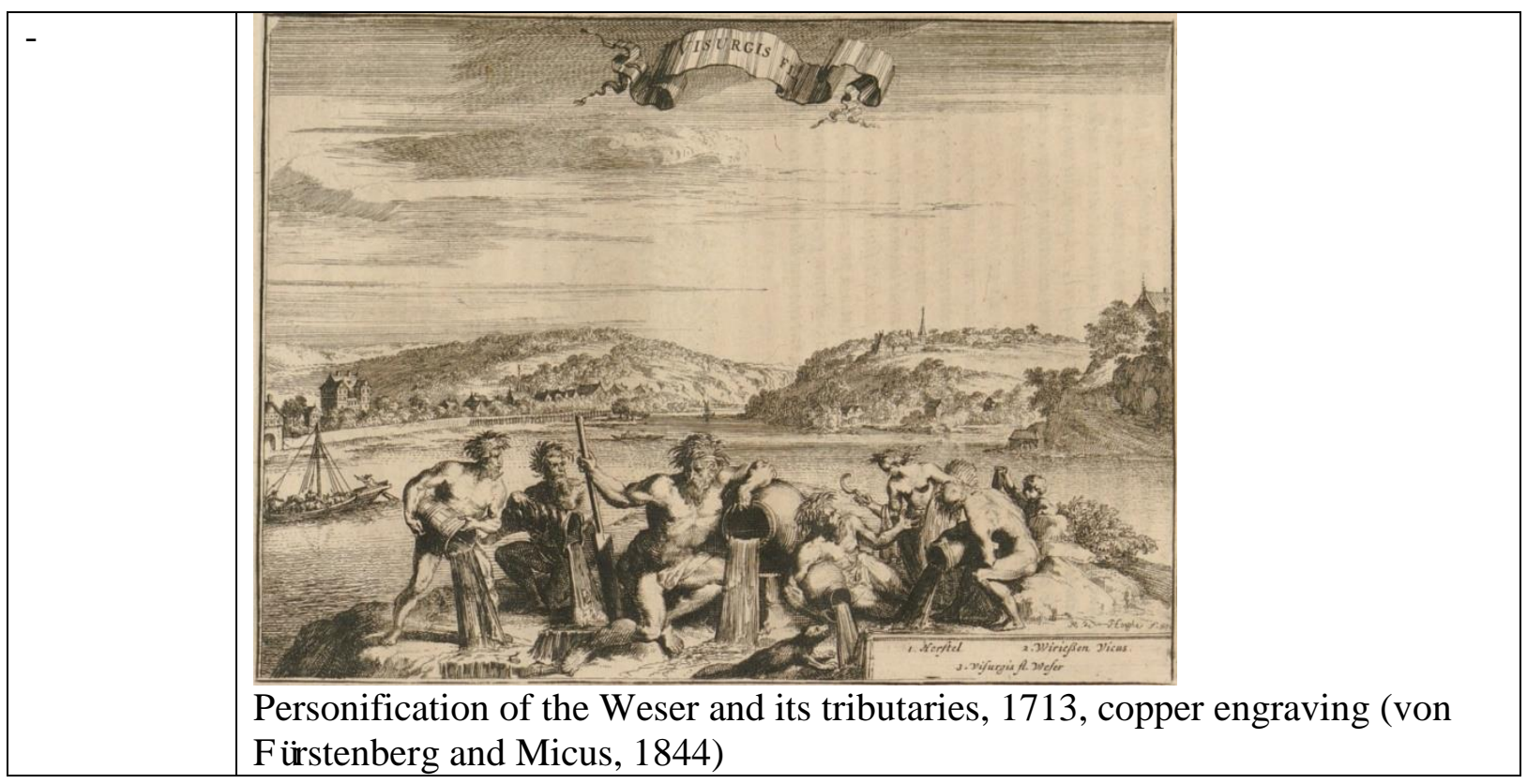

\subsection{Educational}

There are two museums relevant to the Weser River. One is the Weser Renaissance Museum at Brake Castle. Weser Renaissance is a form of architectural style that is found in the area around the Weser in the period between the Reformation and the Thirty Years War, during which the Weser played a significant role in the idea communication and information exchange through the traveling of merchants, artists and scholars on it (Großmann, 1989). The other is the German Fairytales and Weser Legends Museum located in Bad Oeynhausen, which illustrates by known examples who has collected or written fairytales and legends and what is involved in these stories. The German Fairytale Route is also located in the Weser region, where the Brothers Grimm collected diligently the old stories. Unfortunately, there is no museum about the physical geography of the Weser, about the flora and fauna living in the Weser, or about the history of interactions between the Weser and the people around it. Considering the important educational meaning of museums, such a lack should draw the attention of policy-makers for the purpose of protecting the ecosystem of the Weser. 


\subsection{Aesthetic}

There are totally 74 observation platforms along the Weser, most of which are part of churches, palaces or castles. Typical forms in the upstream Weser Uplands are constructions on the hills, such as the Monument of Weser Song in Hann. Münden, the Monument of Kaiser Wilhelm in Porta Westfalica, the Weser Skywalk in Bad Karlshafen, the Kluet Tower in Hameln, or the Klippen Tower in Rinteln. Typical examples in the downstream North German Plains are the observation tower in Lemwerder, the light house and the water tower in Bremen (Figure 2).

\subsection{Recreation and tourism}

The Weser Cycle Route from Hann. Münden to Bremerhaven with the length of $515 \mathrm{~km}$ belongs to the most attractive cycle routes in Germany (ADFC, 2016). It provides peacefulness and recreation in varied landscape, and shapes active and health-conscious leisure time. In addition, the Weser offers a variety of recreational activities, 12 swimming areas, 48 camping sites, and 126 loading stages for boating and cruise can be found along the river. Almost all of the swimming areas are located downstream, because the river downstream is relative wider and the water quality is better. In every village, town and city along the river there is at least one loading stage. The quantity of recreational facilities along the river shows that the Weser is an attractive recreational destination (Figure 2). 


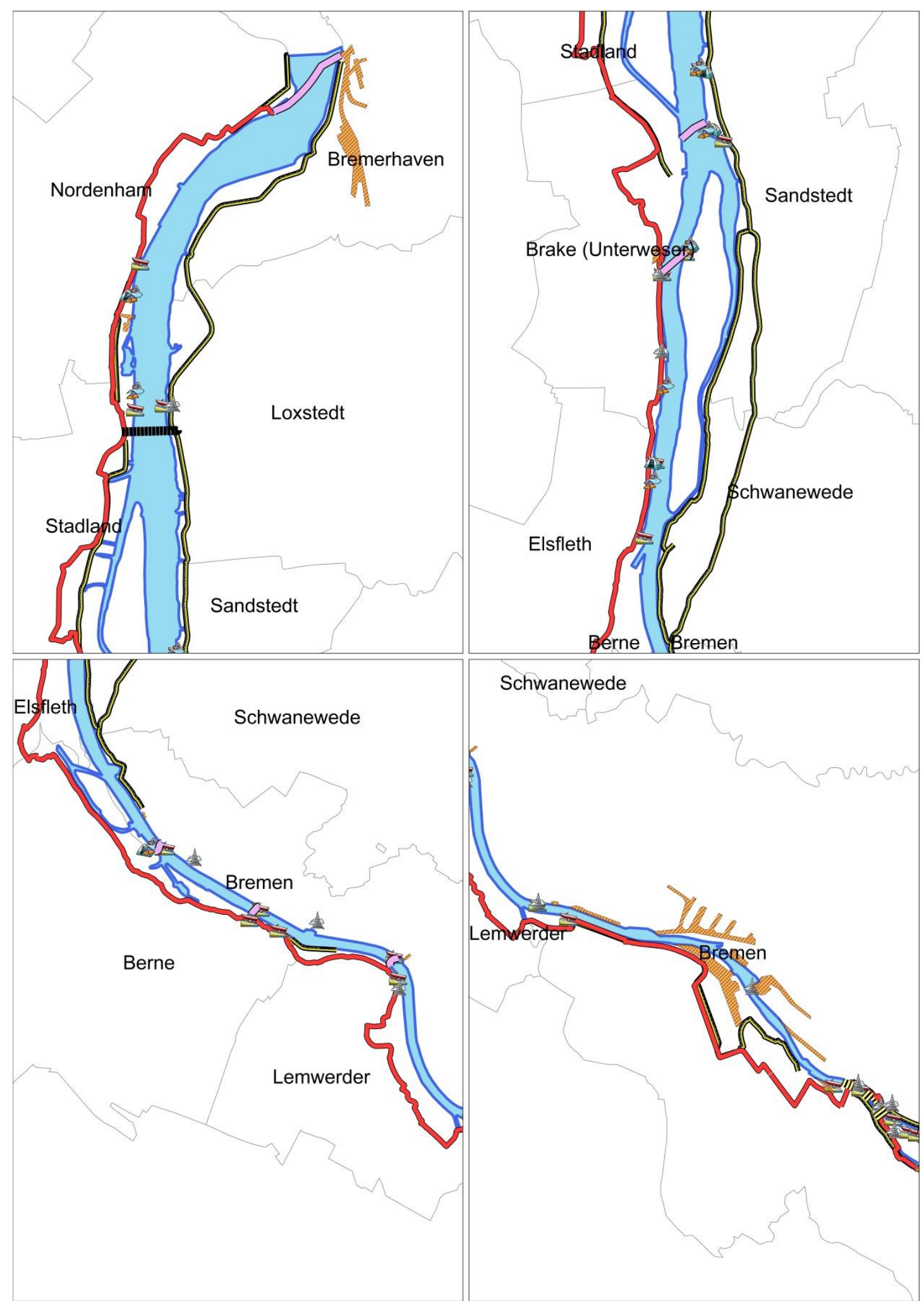

Figure 2: Map of cultural heritage and recreational infrastructure of the Weser (based on BKG, 2013 and BVA, 2013) 


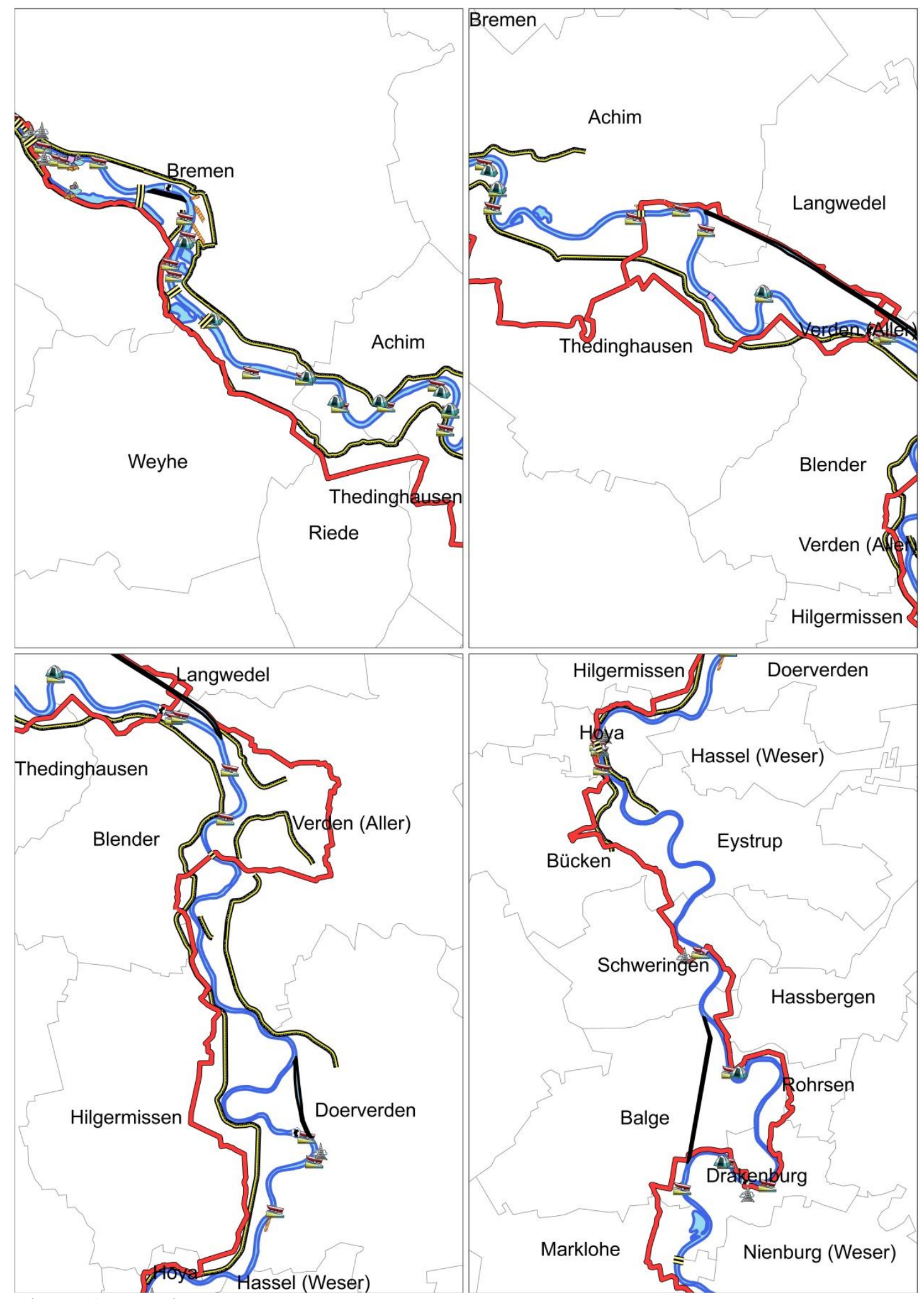

Figure 2: (continue) 


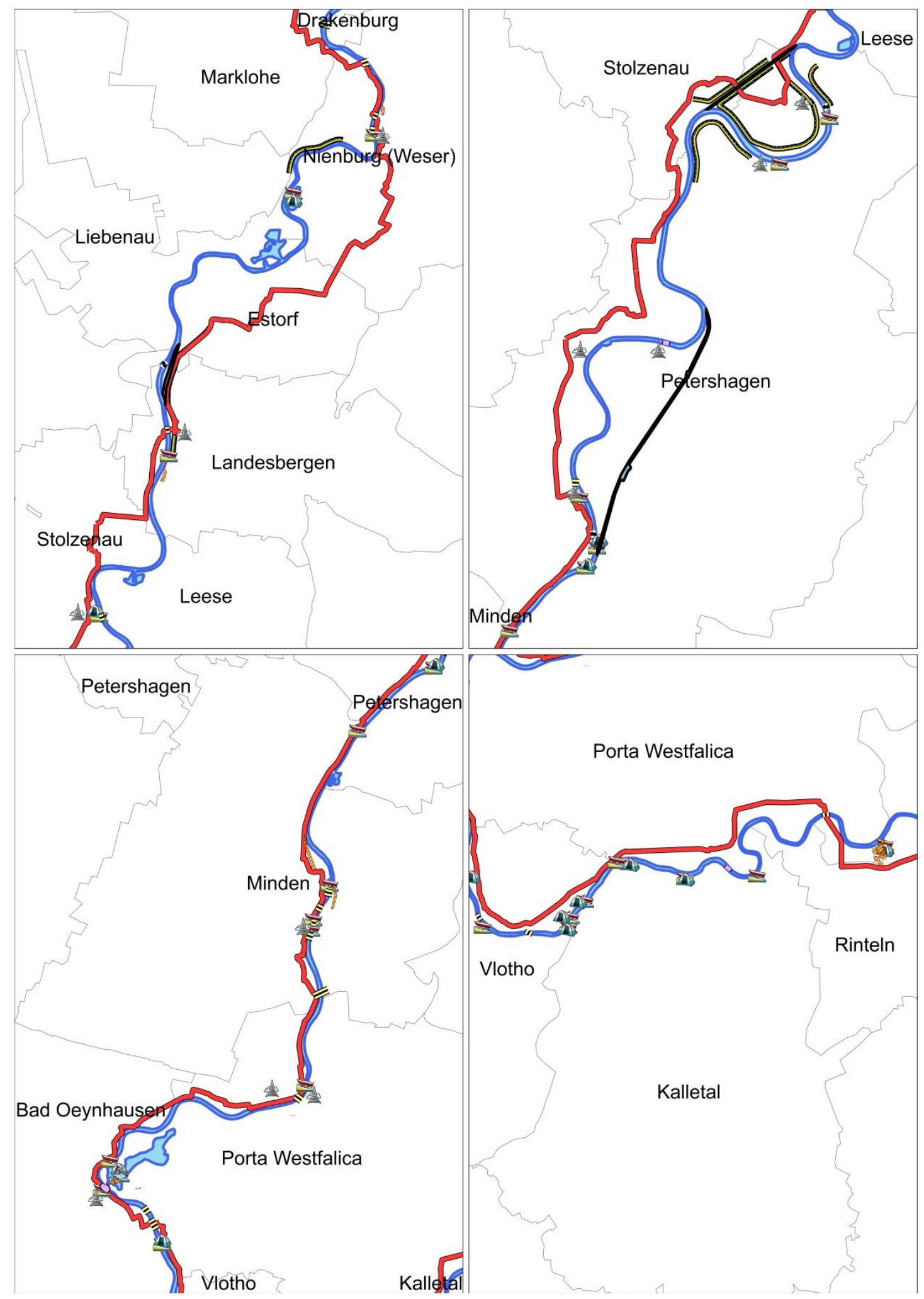

Figure 2: (continue) 


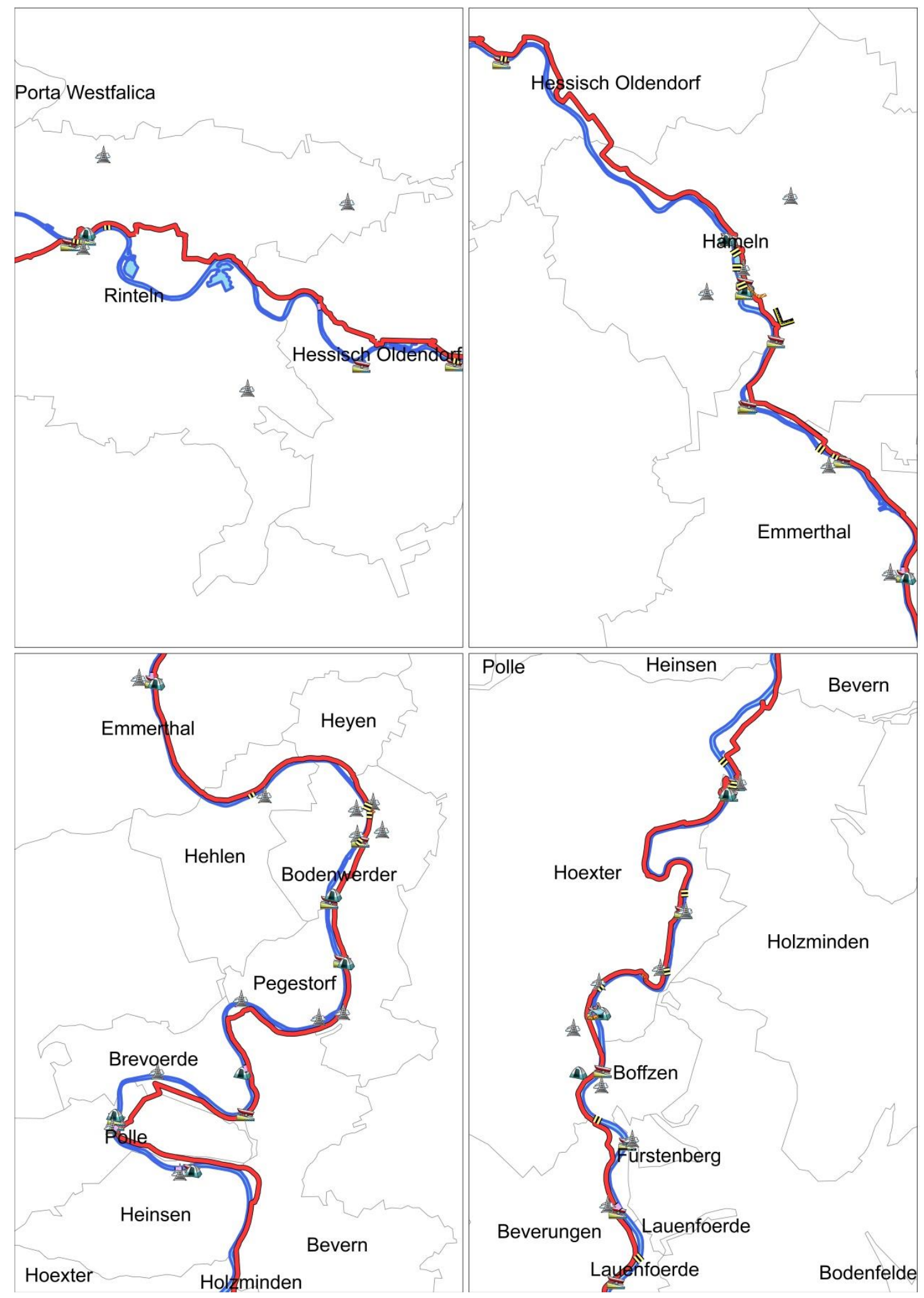

Figure 2: (continue) 


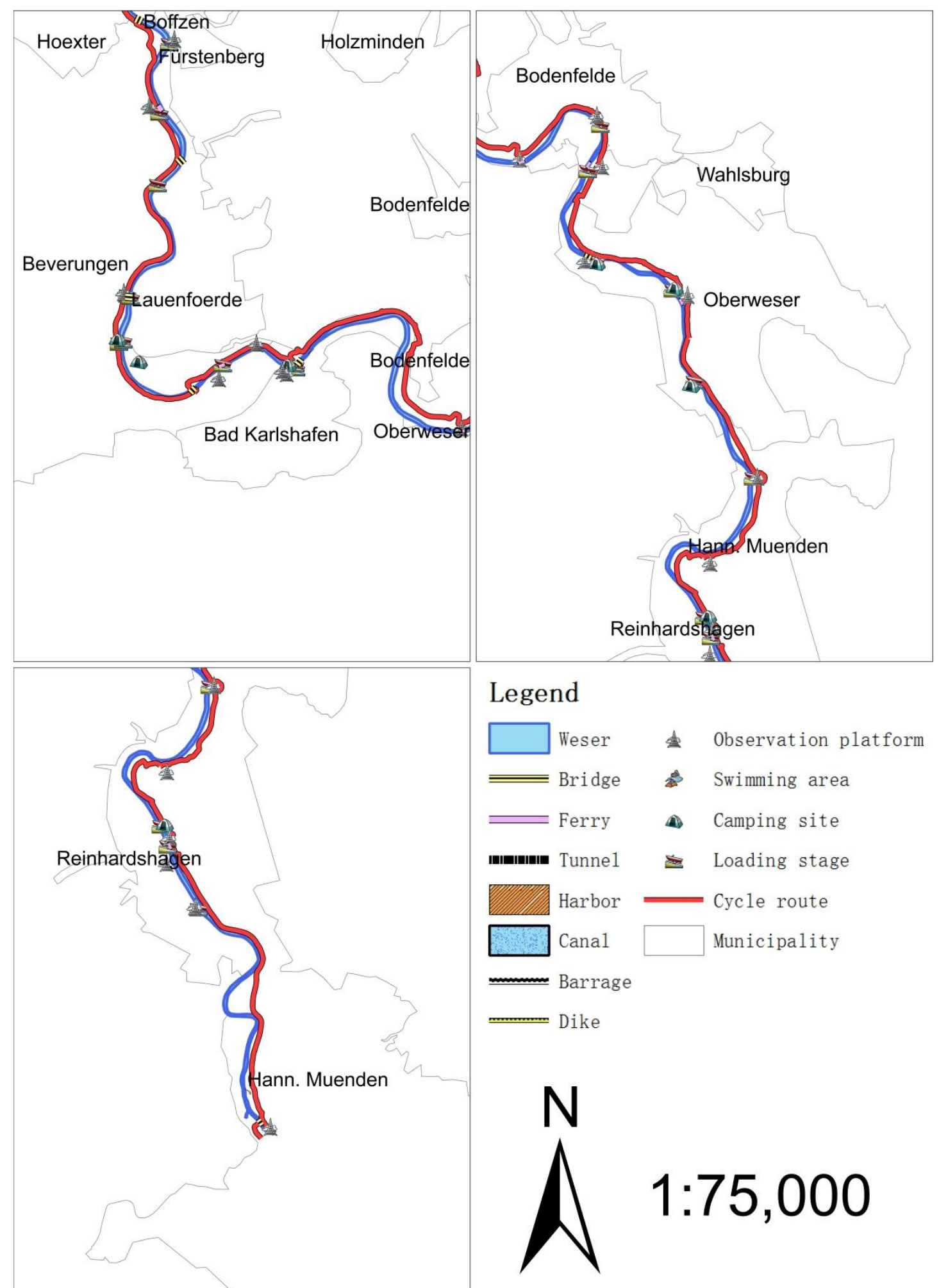

Figure 2: (continue) 


\section{Conclusion}

This paper makes an effort to show what cultural ecosystem services actually are and how these intangible services can be assessed operationally. The indicators we developed are relatively affordable and easy to generalize. The set of indicators for cultural services of a river ecosystem can be refined by identifying more indicators for sense of place and educational service or replacing some indicators for other services. This technique can be applied to other ecosystems such as forests, grasslands or lakes, and can also easily adapt to other ecosystem service framework such as TEEB (2010) or CICES (2013). In summary, indicators should be organized around these specific services to help convey a deeper understanding of the services themselves.

Another advantage of the clearly defined indicators is to avoid double-counting, because an inherent problem of CES is that there is considerable overlap between individual services and the separation of different services is artificial (Tengberg et al., 2012; Plieninger et al., 2013). For instance, cultural heritages can be destinations of tourism while aesthetic enjoyment is a by-product of recreational activities, and people can be inspired during nature-based tourism while sense of place is a kind of inspirational experience. Nevertheless, distinguishing different categories of services facilitate assessment and integration of these services in planning and management of ecosystems.

An indicator system can also reveal deficiency for researchers and policy-makers. The question whether the symbols on coat of arms represent the sense of place of an ecosystem should be empirically tested. The fact that some bridges and ferries have names, e.g. the William-Emperor-Bridge in Bremen and Fairy-Tale-Ferry in Lippoldsberg leads to the 
reasonable suggest that all of the bridges and ferries should be given a name, for names are a special cultural sign of human-being. And it is worth considering building a new museum to present the geology of the Weser, the flora and fauna living in the river, and the history of relationship between people and the river. The inventory collected through indicators can be used to track the performance of environmental programs and regulations such as establishing new observation platforms along the river or managing existent recreational facilities.

CES is an interdisciplinary subject, which needs the cooperation of ecologists, economists, socialists, litterateur, and historians etc. to promote more thorough understanding of it. A particular challenge remains in the economic valuation of CES. Although valuation methods, such as random utility model and choice experiment method, have made great progress, they are still limited to marketable services like recreation and tourism. Most of CES, especially sense of place, religious and inspirational services, have proven resistant to monetary valuation, as they do not rely well on economic assumptions, and their measurement is complicated by the property of intangibility (Kumar and Kumar, 2008; Chan et al., 2011). We hope our research, despite in a qualitative way, would be an advance for economic thinking in the decision-making context.

\section{References}

Alexander, E. P. (1979): Museums in motion. An introduction to the history and functions of museums. Nashville: American Assoc. for State and Local History.

Allgemeiner Deutscher Fahrrad-Club (ADFC) (2016): Bicycle travel analysis.

Below, M. (2011): Die Weser. Vom Thüringer Wald bis zur Nordsee. 2., korr. und aktualis. Aufl. Bremen: Ed. Temmen.

Bielefelder Verlag (BVA) (2013): Weser-Radweg: Vom Weserbergland bis zur Nordsee. Radwanderkarte 1:75.000. 3. Aufl., Neuaufl., mit aktuellem + umfangreichem "Radgeber zum Weser Radweg". Bielefeld: Bielefelder Verlag (BVA). 
Bieling, C. (2014): Cultural ecosystem services as revealed through short stories from residents of the Swabian Alb (Germany). In Ecosystem Services 8, pp. 207-215.

Braun, G.; Hogenberg, F. (1590): Beschreibung und Contrafactur der vornembster Stät der Welt. Cölln (Beschreibung und Contrafactur der vornembster Stät der Welt, 4).

Braun, H.-G.; Eckoldt, M.; Rohde, H. (1998): Die Weser. In Martin Eckoldt (Ed.): Flüsse und Kanäle. Die Geschichte der deutschen Wasserstrassen. 1. Aufl. Hamburg, Herford: DSVVerl.; Busse-Seewald, pp. 135-136.

Chan, K. M. A.; Goldstein, J.; Satterfield, T.; Hannahs, N.; Kikiloi, K.; Naidoo, R. et al. (2011): Cultural services and non-use values. In Peter Kareiva, Heather Tallis, Taylor H. Ricketts, Gretchen C. Daily, Stephen Polasky (Eds.): Natural capital. Theory and practice of mapping ecosystem services. Oxford: Oxford Univ. Press.

Chan, K. M. A.; Guerry, A. D.; Balvanera, P.; Klain, S.; Satterfield, T.; Basurto, X. et al. (2012b): Where are cultural and social in ecosystem services? A framework for constructive engagement. In Bioscience 62 (8), pp. 744-756.

Chan, K. M. A.; Satterfield, T.; Goldstein, J. (2012a): Rethinking ecosystem services to better address and navigate cultural values. In Ecological Economics 74, pp. 8-18.

Church, A.; Fish, R.; Haines-Young, R.; Mourato, S.; Tratalos, J.; Stapleton, L. et al. (2014): UK national ecosystem assessment follow-on. Work package report 5: cultural ecosystem services and indicators.

Costanza, R.; d'Arge, R.; de Groot, R.; Farber, S.; Grasso, M.; Hannon, B. et al. (1997): The value of the world's ecosystem services and natural capital. In Nature 387 (6630), pp. 253 260.

Daily, G. C. (1997): Introduction: What are ecosystem services? In Gretchen C. Daily (Ed.): Nature's services. Societal dependence on natural ecosystems. Washington, DC: Island Press.

Daily, G. C. (Ed.) (1997): Nature's services. Societal dependence on natural ecosystems. Washington, DC: Island Press.

Daniel, T. C.; Muhar, A.; Arnberger, A.; Aznar, O.; Boyd, J. W.; Chan, K. M. A. et al. (2012): Contributions of cultural services to the ecosystem services agenda. In Proceedings of the National Academy of Sciences of the United States of America Proceedings of the National Academy of Sciences of the United States of America 109 (23), pp. 8812-8819.

de Groot, R. S.; Wilson, M. A.; Boumans, R. M. (2002): A typology for the classification, description and valuation of ecosystem functions, goods and services. In Ecological Economics 41 (3), pp. 393-408.

Dewezet (2009): Ein neues Wappen für die neue Samtgemeinde. Räte Bodenwerder und Polle bestimmen neues Siegel - und erinnert damit an die Geschichte. Available online at http://www.dewezet.de/portal/lokales/bodenwerder_Ein-neues-Wappen-fuer-die-neue-

Samtgemeinde-_arid,191761.html, checked on 1/8/2016. 
Dingelstedt, F. v. (1972): Das Wesertal von Münden bis Minden. Hildesheim: Olms.

Eckoldt, M. (Ed.) (1998): Flüsse und Kanäle. Die Geschichte der deutschen Wasserstrassen. 1. Aufl. Hamburg, Herford: DSV-Verl.; Busse-Seewald.

Engel, A. (1990): Weserbuch. Ein erklärender Begleiter auf der Weserreise, mit Berücksichtigung der Fulda von Kassel ab. Hameln: Niemeyer.

European Environment Agency (EEA) (2013): The Common International Classification of Ecosystem Services (CICES). Available online at http://cices.eu/, checked on 11/28/2016.

Federal Agency for Cartography and Geodesy (BKG) (2013): Digital Landscape Model 1 : $250 \quad 000.0$ DLM250. Available online at http://www.geodatenzentrum.de/geodaten/gdz_rahmen.gdz_div?gdz_spr=deu\&gdz_akt_zeile =5\&gdz_anz_zeile=1\&gdz_unt_zeile=1\&gdz_user_id=0, checked on 4/29/2016.

Federal Agency for Cartography and Geodesy (BKG) (2014): Administrative Areas 1 : 250 000 with population numbers. VG250-Ew. Available online at http://www.geodatenzentrum.de/geodaten/gdz_rahmen.gdz_div?gdz_spr=deu\&gdz_akt_zeile $=5 \& g d z \_a n z \_z e i l e=1 \& g d z \_u n t \_z e i l e=15 \& g d z \_u s e r \_i d=0$, checked on 1/12/2017 .

Flecken Langwedel: Das Wappen des Fleckens Langwedel. Available online at http://www.langwedel.de/de-wAssets/docs/leben/Entwicklung-Statistik/Geschichte-desFleckens-Langwedel.pdf, checked on 1/6/2016.

Gee, K.; Burkhard, B. (2010): Cultural ecosystem services in the context of offshore wind farming: a case study from the west coast of Schleswig-Holstein. In Ecological Complexity 7 (3), pp. 349-358.

Gemeinde Dörverden: Wappen. Available online at http://www.doerverden.de/portal/seiten/doerverden-903000058-20620.html, checked on $1 / 6 / 2016$

Gemeinde Emmerthal: Wappen der Gemeinde Emmerthal. Available online at http://www.emmerthal.de/, checked on 1/5/2016.

Gemeinde Loxstedt: Das Wappen der Gemeinde Loxstedt. Available online at http://www.loxstedt.de/leben-in-loxstedt/portrait-der-gemeinde/das-wappen-der-gemeindeloxstedt.69.de.html?mode $=2$, checked on 1/5/2016.

Großmann, G. U. (1989): Renaissance im Weserraum. Band I: Katalog. München: Dt. Kunstverl.

Hernández-Morcillo, M.; Plieninger, T.; Bieling, C. (2013): An empirical review of cultural ecosystem service indicators. In Ecological Indicators 29, pp. 434-444.

Hildebrandt, A. M. (2007): Handbuch der Heraldik. 19., verb. und erw. Aufl. Hamburg: Nikol. 
Hoffmann von Fallersleben, August Heinrich (1973): Auswahl in drei Teilen. Werke I. Hildesheim: Georg Olms Verlag.

Jacobs, S.; Dendoncker, N.; Keune, H. (Eds.) (2014): Ecosystem services. Global issues, local practices. Amsterdam, Boston, Heidelberg, London: Elsevier.

Kareiva, P.; Tallis, H.; Ricketts, T. H.; Daily, G. C.; Polasky, S. (Eds.) (2011): Natural capital. Theory and practice of mapping ecosystem services. Oxford: Oxford Univ. Press.

Kastler, J.; Lüpkes, V. (Eds.) (2000): Die Weser. EinFluss in Europa. Aufbruch in die Neuzeit. Weserrenaissance-Museum Schloss Brake, Lemgo. Holzminden: Mitzkat.

Kumar, M.; Kumar, P. (2008): Valuation of the ecosystem services: a psycho-cultural perspective. In Ecological Economics 64 (4), pp. 808-819.

Landkreis Holzminden: Wappen. Available online at http://www.landkreisholzminden.de/staticsite/staticsite.php?menuid=22\&topmenu=21\&keepmenu=inactive, checked on $1 / 6 / 2016$.

Landkreis Verden: Wappen des Landkreises Verden. Available online at https://www.landkreis-verden.de/landkreis-und-politik/landkreis/wappen-des-landkreises/, checked on $1 / 6 / 2016$.

Landkreis Wesermarsch: Wappenbeschreibung. Available online at http://www.landkreiswesermarsch.de/unser-landkreis/wappen.php, checked on 1/6/2016.

Leonhard, W. (1976): Das große Buch der Wappenkunst. Entwicklung, Elemente, Bildmotive, Gestaltung. München: Callwey.

Löbe, K. (1969): Das Weserbuch. Roman eines Flusses. 2. Aufl. Hameln: Niemeyer.

MA (2003): Ecosystems and human well-being. A framework for assessment. Washington, DC: Island.

MA (2005): Ecosystems and human well-being. Current state and trends, volume 1. Washington, DC: Island Press.

Marbach, G. O. (1841): Deutsche Lieder zu Schutz und Trutz. Leipzig, Leipzig: Wigand; Breitkopf und Härtel.

Merian, M. (1961): Topographia Westphaliae. Neue Ausg. Kassel: Bärenreiter-Verl.

Merian, M.; Wüthrich, L. H. (1961): Topographia Braunschweig und Lüneburg. Neue Ausg. Kassel: Bärenreiter.

Merian, M.; Wüthrich, L. H. (Eds.) (1962): Topographia Saxoniae inferioris. Neue Ausg. Kassel: Bärenreiter-Verl. 
Milcu, A. I.; Hanspach, J.; Abson, D.; Fischer, J. (2013): Cultural ecosystem services: a literature review and prospects for future research. In Ecology and Society 18 (3), p. 44.

Musculus, J. C.; Eckhardt, A. (1985): Der Deichatlas des Johann Conrad Musculus von 1625/26. Oldenburg: Holzberg.

Paetow, K. (1974): Die schönsten Wesersagen. Das sind Sagen, Legenden, Begebnisse, Historien, Lügenmären und Nachrichten von Zauberbergen, Ritterburgen, alten Städten, Steinen, Brunnen, Heiligen, Hexen, weisen Frauen, Riesen, Zwergen, Spukedingern sowie verwegenen und absonderlichen Käuzen. Nach den Überlieferungen aus schriftlichen und mündlichen Quellen zusammengetragen, in Stromrichtung geordnet und neu erzählt. 3. durchgesehene und erweiterte Auflage. Hameln: Sponholtz.

Pilgrim, S.; Pretty, J. (Eds.) (2010): Nature and culture. Rebuilding lost connections. London: Earthscan.

Pilgrim, S.; Pretty, J. (2010): Nature and culture: an introduction. In Sarah Pilgrim, Jules Pretty (Eds.): Nature and culture. Rebuilding lost connections. London: Earthscan.

Plieninger, T.; Dijks, S.; Oteros-Rozas, E.; Bieling, C. (2013): Assessing, mapping, and quantifying cultural ecosystem services at community level. In Land Use Policy 33, pp. 118129.

Raabe, W. (1968): Der heilige Born. Göttingen: Vandenhoeck \& Ruprecht.

Rogge, A. (1958): An Deich und Strom. Ausgewählte Erzählungen. Bremen: Schünemann.

Samtgemeinde Hoya: Wappenbeschreibungen.

Samtgemeinde Mittelweser: Gemeinde Estorf. Available online at https://www.sgmittelweser.de/die-samtgemeinde/gemeinde-estorf/, checked on 1/6/2016.

Samtgemeinde Mittelweser: Gemeinde Landesbergen. Available online at https://www.sgmittelweser.de/die-samtgemeinde/gemeinde-landesbergen/, checked on 1/6/2016.

Samtgemeinde Mittelweser: Gemeinde Leese. Available online at https://www.sgmittelweser.de/die-samtgemeinde/gemeinde-leese/, checked on 1/6/2016.

Samtgemeinde Mittelweser: Geschichte und Wappen. Available online at https://www.sgmittelweser.de/die-samtgemeinde/, checked on 1/6/2016.

Samtgemeinde Thedinghausen: Gemeinde Blender. Available online at http://www.thedinghausen.de/unsere-samtgemeinde/geschichtliches/gem-blender/, checked on $1 / 6 / 2016$.

Samtgemeinde Thedinghausen: Gemeinde Riede. Available online at http://www.thedinghausen.de/unsere-samtgemeinde/geschichtliches/gem-riede/, checked on $1 / 6 / 2016$. 
Satterfield, T.; Slovic, S. (Eds.) (2004): What's nature worth? Narrative expressions of environmental values. Salt Lake City, Utah: University of Utah Press.

Stadler, K. (1970): Die Gemeindewappen der Bundesländer Niedersachsen und SchleswigHolstein. Bremen: Angelsachsen-Verl.

Strack, A. W.; Albrecht, T. (1997): Malerische Reise durch das Weserbergland. Anton Wilhelm Strack, Hofmaler und Professor für Zeichenkunst in Bückeburg (1758 - 1829); eine Ausstellung im Niedersächsischen Staatsarchiv Bückeburg, Schloß, vom 2. Juni bis 18. Juli 1997. Bückeburg: Verl. Createam.

Taylor, B. R. (Ed.) (2005): The encyclopedia of religion and nature. London: Thoemmes Continuum.

TEEB (2010): The economics of ecosystems and biodiversity. Ecological and economic foundations. London: Earthscan.

Tengberg, A.; Fredholm, S.; Eliasson, I.; Knez, I.; Saltzman, K.; Wetterberg, O. (2012): Cultural ecosystem services provided by landscapes: Assessment of heritage values and identity. In Ecosystem Services 2, pp. 14-26.

United Nations Educational, Scientific and Cultural Organization (UNESCO) (1972): Convention concerning the protection of the world cultural and natural heritage. Adopted by the General Conference at its seventeenth session Paris, 16 november 1972. Paris. Available online at http://whc.unesco.org/archive/convention-en.pdf, checked on 1/8/2016.

United Nations Educational, Scientific and Cultural Organization (UNESCO) (2003): Convention for the safeguarding of the intangible cultural heritage. Paris. Available online at http://unesdoc.unesco.org/images//0013/001325/132540e.pdf, checked on 1/11/2016.

van Reeth, W. (2014): Ecosystem service indicators: Are we measuring what we want to manage. In Sander Jacobs, Nicolas Dendoncker, Hans Keune (Eds.): Ecosystem services. Global issues, local practices. Amsterdam, Boston, Heidelberg, London: Elsevier.

Veddeler, P. (2003): Wappen, Siegel, Flaggen. Die kommunalen Hoheitszeichen des Landschaftsverbandes, der Kreise, Städte und Gemeinden in Westfalen-Lippe. Münster: Ardey.

von Fürstenberg, F.; Micus, F. J. (1844): Denkmale des Landes Paderborn. Paderborn: Junfermann.

Woodcock, T.; Robinson, J. M. (1989): The Oxford guide to heraldry. Oxford: Oxford University Press. 


\section{Summary}

This dissertation with the title "The Valuation of River Ecosystem Services" consists of three papers. It begins with the retrospect of the historical development of cost-benefit analysis and the non-market valuation techniques (Paper 1 and 2). We highlight that the origin of costbenefit analysis in America rooted in the water resource management, including navigation, flood control, irrigation and water power, which are deemed ecosystem services of rivers today. This means that cost-benefit analysis has dealt with the valuation of ecosystem services from its very beginning. In the long history of cost-benefit analysis from France to America, the concept consumers' surplus was introduced by Dupuit which provided a basis to the later development of non-market valuation methods, and market-based valuation methods were established by the Green Book. When economists took part in the work of cost-benefit analysis in the 1950 s, they made great effort to develop a variety of non-market valuation techniques and applied them to value air quality, water quality and recreational activities. These methods, market-based together with non-market, have played and will still play a pivotal role in the current context of the economic valuation of ecosystem services.

Focusing on the regulating services of floodplain ecosystems in Lower Saxony, the principle of cost-benefit analysis and market-based valuation methods are applied in the third paper to search suitable areas for the establishment of riparian forests, which have currently drawn great attention due to their contributions to flood control, nutrient retention, carbon storage, as well as their provisions of habitats and migration corridors for plants and animals. The identification of suitable areas is realized by an ecological-economic selection criterion, which consists of a net present value and a set of ecological factors. To calculate the net present value, the costs for land purchasing and afforestation, the benefits of flood control, 
nutrient retention, carbon storage and biodiversity are considered. The ecological factors include land use type, part of floodplain, floodplain status, area of land, priority area (e.g. conservation area), flood risk, as well as habitat quality. A data bank created from various data sources by means of ArcGIS shows the spatial position of all potential areas and all the attributes of every area. The areas selected by the ecological factors make clear, how much net benefit a specific area can yield through the establishment of riparian forest. From a methodological point of view this study supplement the traditional cost-benefit analysis by the fact that the method used attempts to define the possible alternatives (suitable areas for floodplain forest establishment) under certain political objectives (improving the floodplains) based on the net monetary benefit and ecological factors. In addition, the set of factors is flexible to change according to different policy requirements.

The final paper turns attention to the cultural ecosystem services of rivers, which is a road less traveled. Through a case study on the Weser River in Germany, this paper aims to answer the questions what the cultural ecosystem services actually are and how these intangible services can be operationally assessed. In the MA framework we identify a set of clearly defined indicators for all categories of cultural services. Since these categories are usually interrelated and overlapping, the advantage of this approach is to avoid double-counting. Coats of arms are chosen as the indicator for the service category sense of place; bridges, ferries, canals, harbours, barrages and dikes for cultural heritage; legends, poems, novels, songs and paintings for the inspirational service; museums for the educational service; observation platforms for the aesthetic service; cycle route, swimming areas, landing stages for boating and shipping, and camping sites for the recreational service. Although the cultural services are 
assessed in a qualitative way, we hope that our findings will provide insight for the work of economic valuation in the future. 